\section{Pacific Northwest}

National Laboratory

Operated by Battelle for the

U.S. Department of Energy

\title{
Np Behavior in Synthesized Uranyl Phases: Results of Initial Tests
}

\author{
J. I. Friese \\ M. Douglas \\ B. K. McNamara \\ S. B. Clark \\ B. D. Hanson
}

September 2004

Prepared for the U.S. Department of Energy under Contract DE-AC06-76RL01830 


\title{
DISCLAIMER
}

This report was prepared as an account of work sponsored by an agency of the United States Government. Neither the United States Government nor any agency thereof, nor Battelle Memorial Institute, nor any of their employees, makes any warranty, express or implied, or assumes any legal liability or responsibility for the accuracy, completeness, or usefulness of any information, apparatus, product, or process disclosed, or represents that its use would not infringe privately owned rights. Reference herein to any specific commercial product, process, or service by trade name, trademark, manufacturer, or otherwise does not necessarily constitute or imply its endorsement, recommendation, or favoring by the United States Government or any agency thereof, or Battelle Memorial Institute. The views and opinions of authors expressed herein do not necessarily state or reflect those of the United States Government or any agency thereof.

\author{
PACIFIC NORTHWEST NATIONAL LABORATORY \\ operated by \\ BATTELLE \\ for the \\ UNITED STATES DEPARTMENT OF ENERGY \\ under Contract DE-ACO6-76RLO183O
}

This document was printed on recycled paper.

$(8 / 00)$ 


\title{
Np Behavior in Synthesized Uranyl Phases: Results of Initial Tests
}

\author{
J. I. Friese \\ M. Douglas \\ B. K. McNamara \\ S. B. Clark \\ B. D. Hanson
}

September 2004

Prepared for

the U.S. Department of Energy

under Contract DE-AC06-76RL01830

Pacific Northwest National Laboratory

Richland, Washington 99352 


\section{Summary}

Initial tests were completed at Pacific Northwest National Laboratory for developing a potential mechanism to retard the mobility of neptunium at the Yucca Mountain repository. Neptunium is of concern because of its mobility in the environment and long half life, contributing a large percentage of the potential dose over extended times at the perimeter of the site. The mobility of neptunium could be retarded by its association with uranium mineral phases. The following four uranium mineral phases were examined and are potential secondary phases expected to form as a result of interactions of spent nuclear fuel with the local environment: meta-schoepite, studtite, uranophane, and sodium boltwoodite. The fate of the neptunium was examined in these synthetic experiments.

Relevant scientific literature was used in developing the synthetic methods for forming the uranium solids. Two trends were observed in these initial tests: 1) minerals that have charged sheets and cations in the inner layer can uptake neptunium more readily than neutral sheet/chain structures and 2) uranium solids that have neptunium associated with them have a lower crystallinity than pure uranium solids. Neptunium was not associated with meta-schoepite in these tests, with the exception of one sample at higher $\mathrm{pH}$ than the others. However, uranophane, sodium boltwoodite, and studtite had neptunium associated with them under the experimental conditions examined. This was a preliminary indication that neptunium may be associated with these uranium mineral phases if they form under repository conditions. Although not conclusive, the evidence suggests that the neptunium is incorporated in some uranium phases as opposed to simply being sorbed on the surface. 


\section{Acronyms}

$\begin{array}{ll}\text { DIW } & \text { deionized water } \\ \text { EELS } & \text { electron energy loss spectroscopy } \\ \text { GEA } & \text { gamma energy analysis } \\ \text { KPA } & \text { kinetic phosphorescence analysis } \\ \text { LRB } & \text { laboratory record book } \\ \text { LSC } & \text { liquid scintillation counting } \\ \text { PNNL } & \text { Pacific Northwest National Laboratory } \\ \text { SEM } & \text { scanning electron microscopy } \\ \text { SNF } & \text { spent nuclear fuel } \\ \text { TEM } & \text { transmission electron microscopy } \\ \text { XRD } & \text { x-ray diffraction } \\ \text { EDS } & \text { energy dispersive spectroscopy }\end{array}$




\section{Contents}

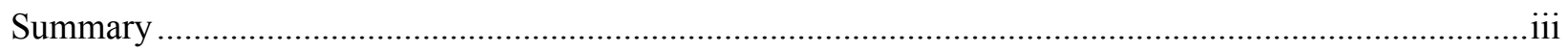

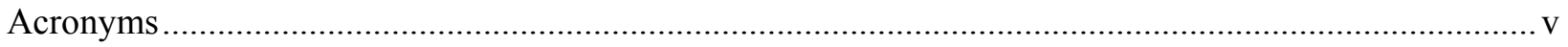

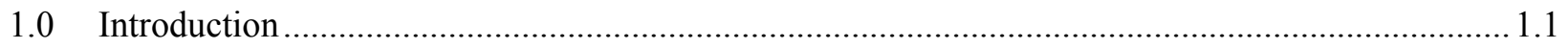

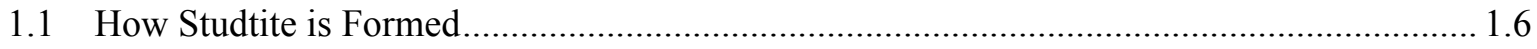

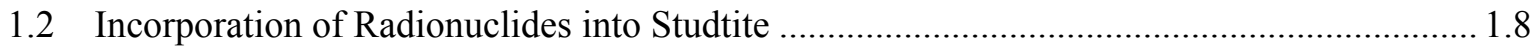

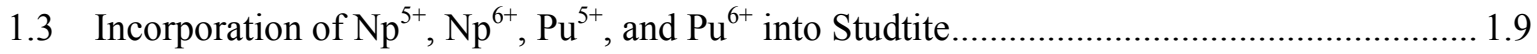

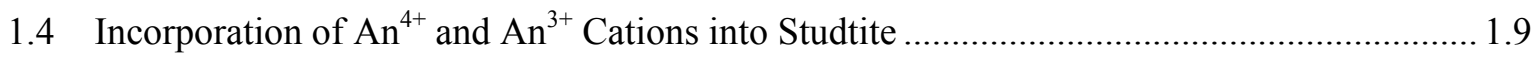

1.5 Experimental Evidence for Association of $\mathrm{Np}$ in U(VI) Minerals .................................. 1.10

1.6 Experiments Presented in this Report.................................................................... 1.10

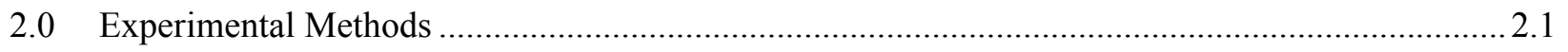

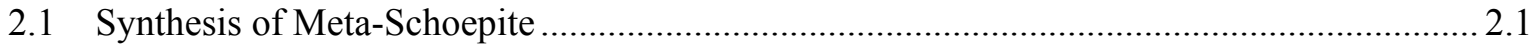

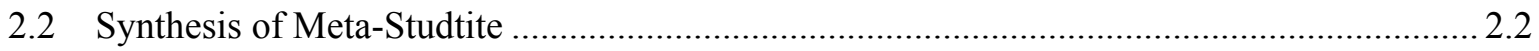

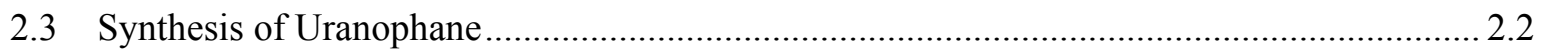

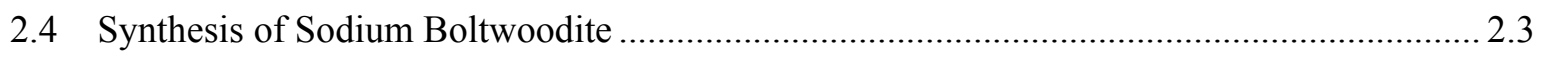

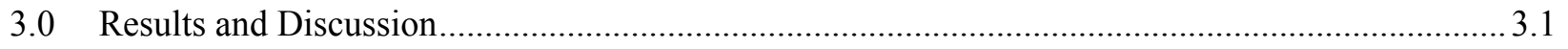

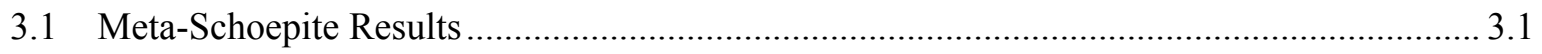

3.1.1 SEM and EDS Data for Sample 4-18-03B …......................................................... 3.3

3.1.2 Meta-Schoepite pH Series Data (samples M2 and M5 through M7) ....................... 3.15

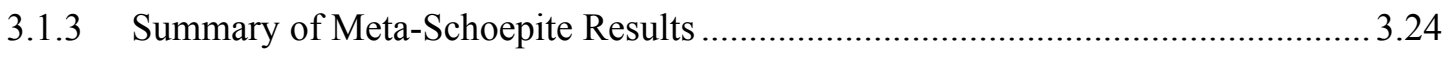

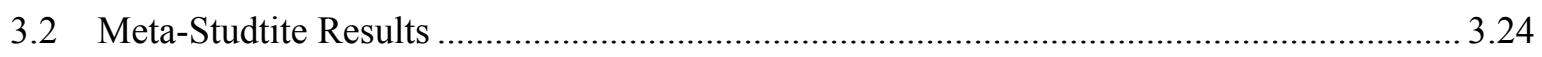

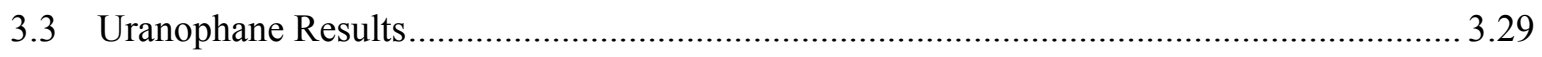

3.3.1 Characterization of the First Uranophane Synthesis Set .......................................3.29

3.3.2 Characterization of the Second Uranophane Synthesis Set....................................3.36 
3.3.3 XRD Data and Lattice Parameters on Samples U1 to U3 ...........................................

3.3.4 SEM Micrographs and EDS Spectra for Samples U1 through U4 ........................... 3.41

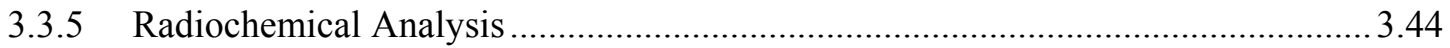

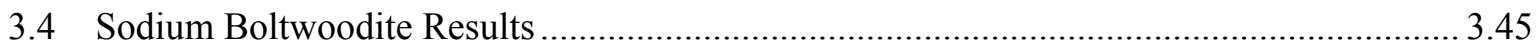

3.5 Overall Trends in Neptunium Association with Uranium Minerals.................................... 3.47

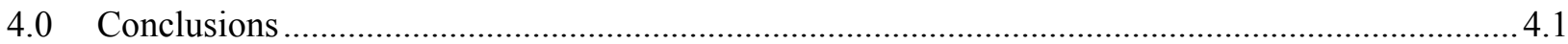

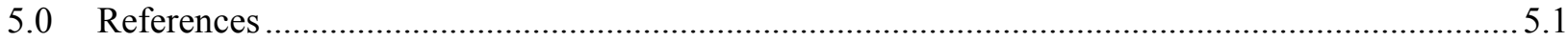

\section{Figures}

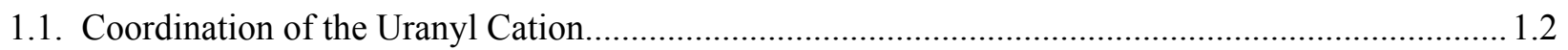

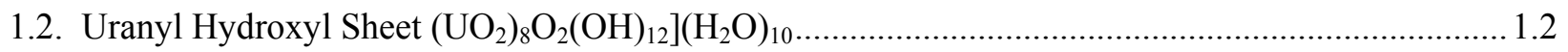

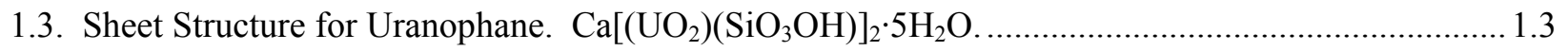

1.4. Structure of Studtite with its Waters of Hydration......................................................................... 1.7

3.1. XRD Patterns of Two Samples from Meta-Schoepite Synthesis (4-18-03A and 4-18-03B)............ 3.2

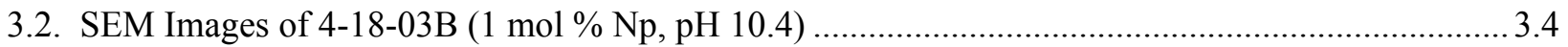

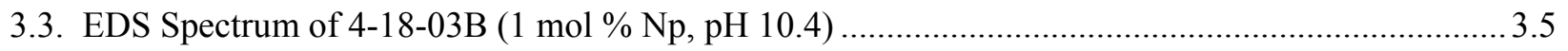

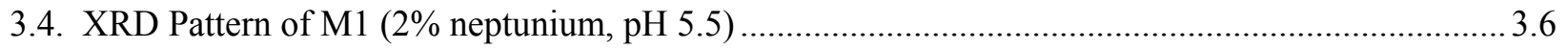

3.5. XRD Pattern of M1 (2\% neptunium, pH 5.5) ...........................................................................

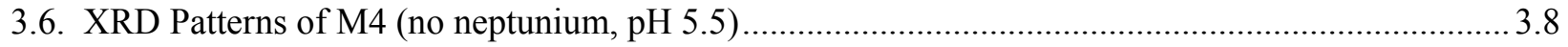

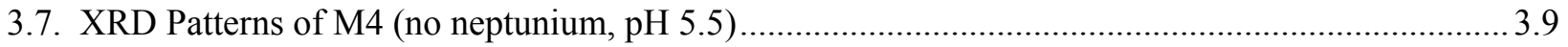

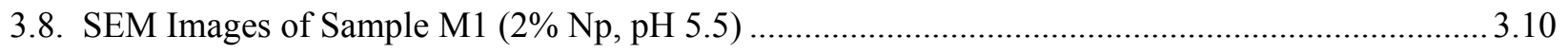

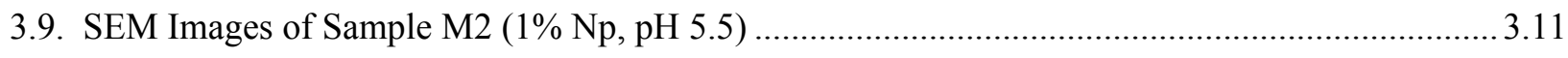

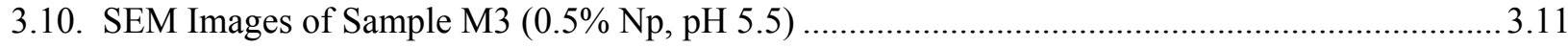

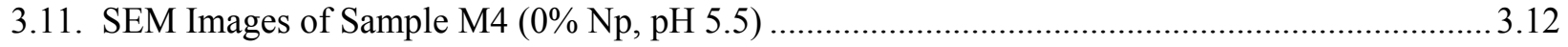

3.12. EDS Spectra of Samples M1 (2\% Np, pH 5.5) and M2 (1\% Np, pH 5.5) ....................................13

3.13. EDS Spectra of Samples M3 (0.5\% Np, pH 5.5) and M4 (0\% Np, pH 5.5) ............................... 3.14

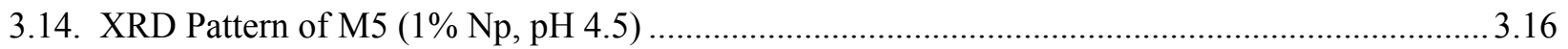


3.15. XRD Pattern of M6 (1\% Np, pH 6.5)

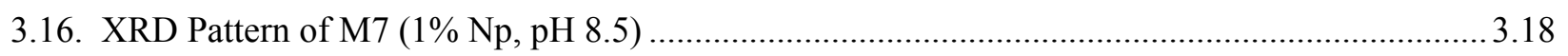

3.17. SEM Micrographs of Sample M5 (meta-schoepite, 1\% Np, pH 4.5) .............................................. 19

3.18. SEM Micrographs of Sample M6 (meta-schoepite, $1 \%$ Np, pH 6.5) ......................................... 3.20

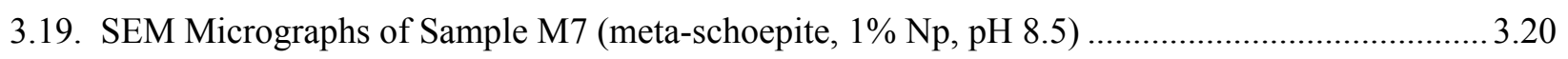

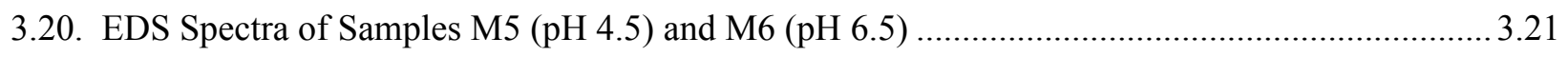

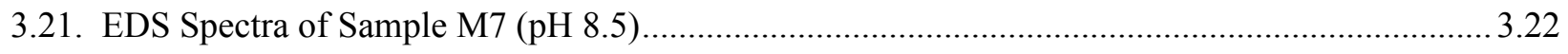

3.22. Neptunium Solution Concentration in Meta-Schoepite $\mathrm{pH}$ Series.............................................. 3.23

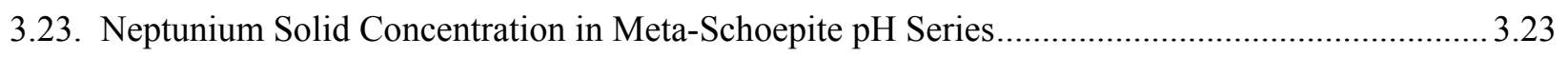

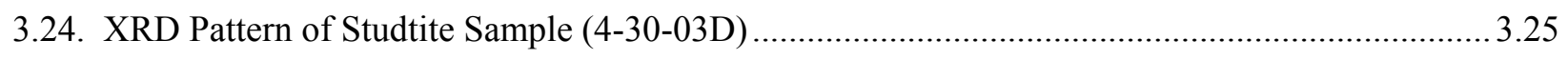

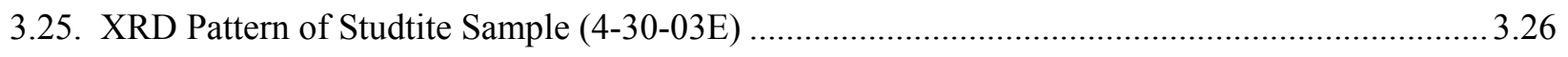

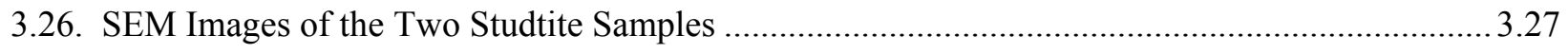

3.27. EDS Spectrum of Neptunium Associated Studtite Sample (4-30-03D) ........................................28

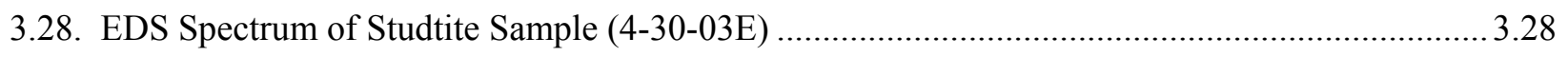

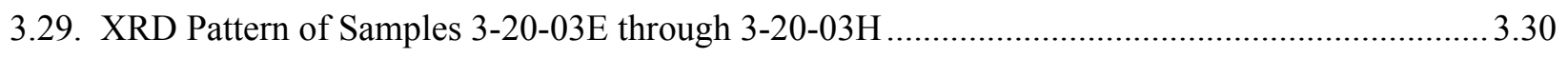

3.30. XRD Pattern of 4-30-03A. 780 ppm Np in the Sample ...........................................................3.31

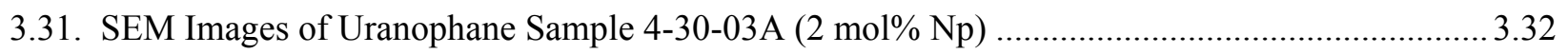

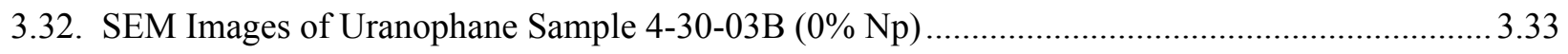

3.33. SEM Images of Samples 3-20-03E (2 mol \% Np), 3-20-03F (1 mol \% Np), 3

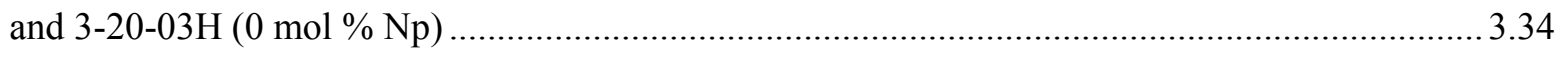

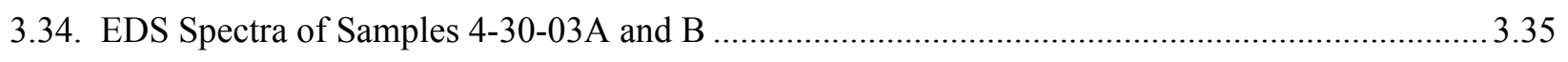

3.35. EDS Spectra of the 3-20-03 Samples E, F, and H respectively ................................................ 3.35

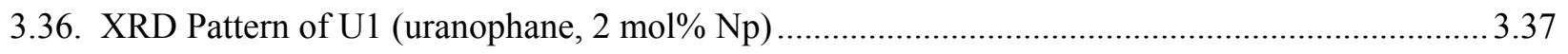

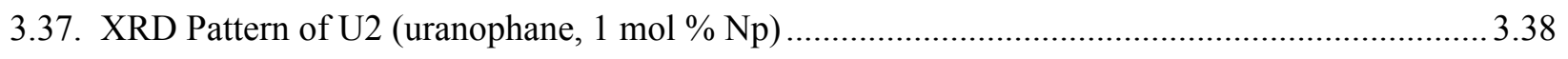

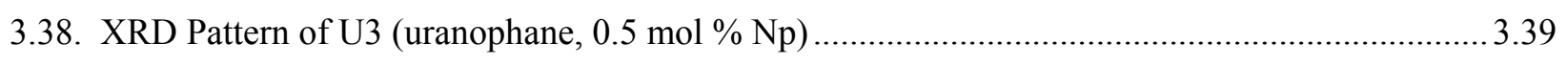

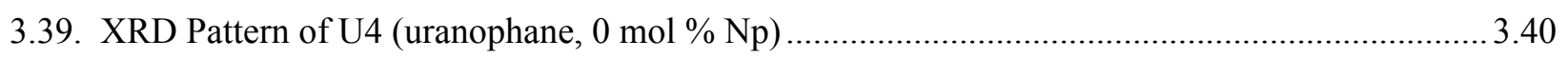

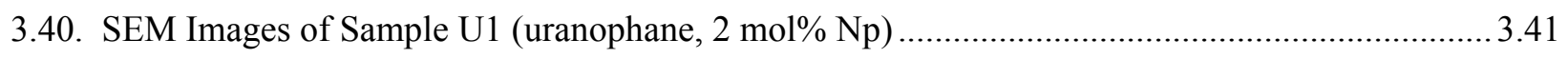

3.41. SEM Images of Sample U2 (uranophane, 1 mol\% Np) ...............................................................42

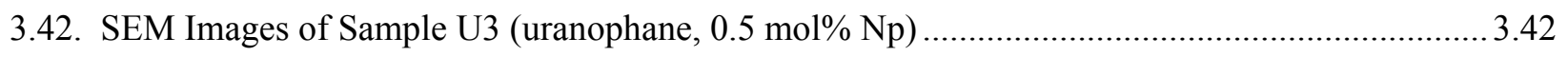

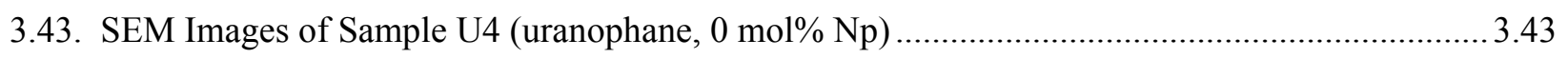

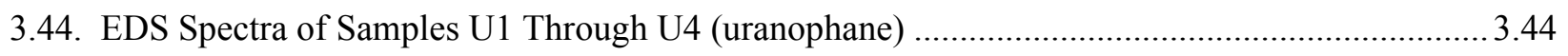


3.45. Radiochemical Analysis of Second Uranophane Synthesis Set Showing \% Np

\section{Tables}

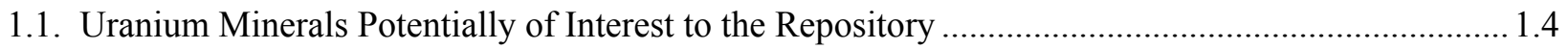

3.1. First Set of Radiochemical Data from Initial Meta-Schoepite Tests at Various Neptunium Concentrations

3.2. Radiochemical Data from Meta-Schoepite Tests for Transformation to Studtite.

3.3. Second Set Test Matrix, Meta-schoepite …................................................................................ 3.2

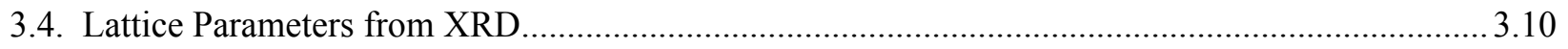

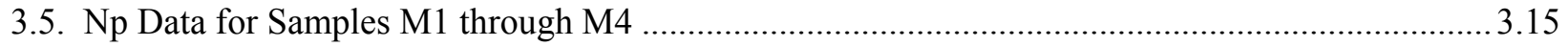

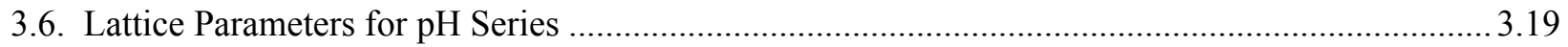

3.7. Radiochemical Data from Meta-Studtite Tests at Various Neptunium Concentrations ..................3.24

3.8. Radiochemical Data from Uranophane Tests at Various Neptunium Concentrations ..................... 3.29

3.9. Neptunium Concentrations and Labeling for Second Set .......................................................... 3.36

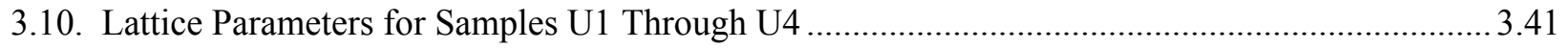

3.11. Radiochemical Data from Sodium Boltwoodite Tests at Various Neptunium Concentrations ..... 3.46 


\subsection{Introduction}

The proposed repository at the Yucca Mountain site in Nevada is the potential site for placement of high-level radioactive waste in the United States. The movement of radioactive material through the environment at this site has undergone extensive scientific study. Because of its mobility in the environment and long half life, neptunium contributes a large percentage of the potential dose at extended times at the perimeter of the site. The tests presented in this report examine a potential mechanism for retarding the mobility of neptunium in the repository.

Neptunium, as presently modeled (CRWMS M\&O 2003) as controlled by the solubility of $\mathrm{Np}_{2} \mathrm{O}_{5}$, will be the major contributor to long-term dose if released from the repository. A fundamental understanding of neptunium's interaction with altered spent fuel is necessary to develop a realistic model for neptunium release. The incorporation of neptunium may depend on many variables, including uranium mineral phase, temperature, $\mathrm{pH}$, solution chemistry, radiolysis field, and oxidation state of $\mathrm{Np}$, among others. The incorporation or sorption of neptunium into/onto uranium mineral phases is of interest because of uranium's capability to limit the mobility of the neptunium into the environment (Burns 1997). This document presents the results of initial tests completed at Pacific Northwest National Laboratory (PNNL) and indicates a path forward for future testing.

There are many potential uranium minerals that have been proposed to form, and a large list of these minerals was published by Chen, Ewing, and Clark (1999). Out of this list, metaschoepite, uranophane, and sodium boltwoodite were chosen because they have been observed in natural analogue systems (Finch 1992). Studtite and metastudtite have recently become of interest because of observing the mineral on SNF (McNamara 2002, 2004) and other studies involving these minerals (Kubatko 2003).

Uranium minerals typically consist of three uranium building blocks, tetra, penta, and hexa bipyramidal geometries around the equatorial plane of the cation as shown in Figure 1.1. These various polyhedra can polymerize in a myriad of combinations to form various minerals. Figure 1.2 indicates a sheet of pentagonal bipyramids linked together to form a uranyl hydroxide mineral. Likewise, if other anions or cations are present, these building blocks can form mixed-element minerals as is shown in Figure 1.3. These sheet structures can be neutral (like schoepite) or charged (like uranophane). The ability of minerals to uptake neptunium into their structures will depend on the chemical environment. 
(a)
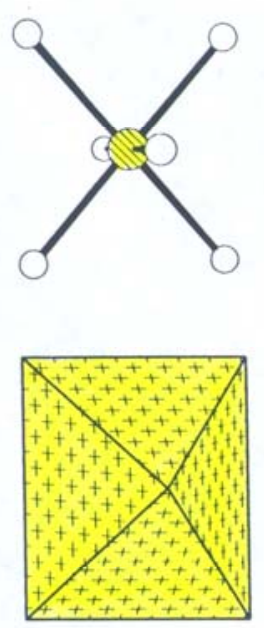

$U r \phi_{4}$ (b)
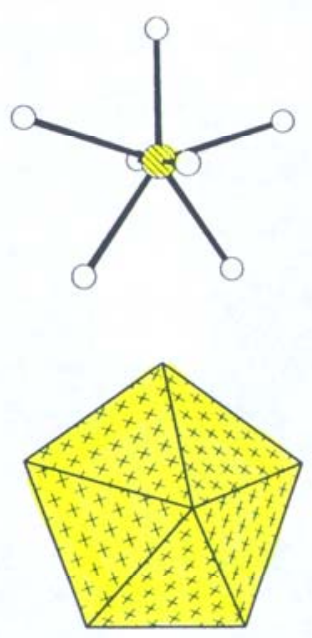

$U r \phi_{5}$ (c)
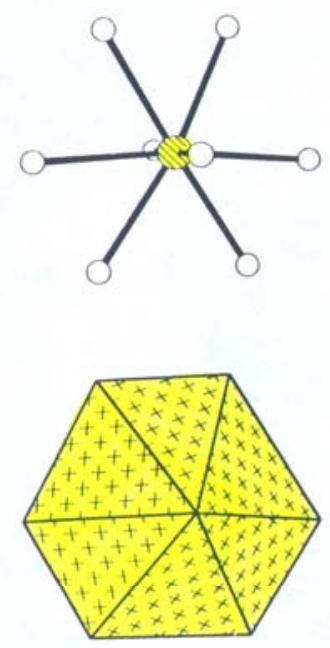

$U r \phi_{6}$

Figure 1.1. Coordination of the Uranyl Cation (adapted from Burns 1999)

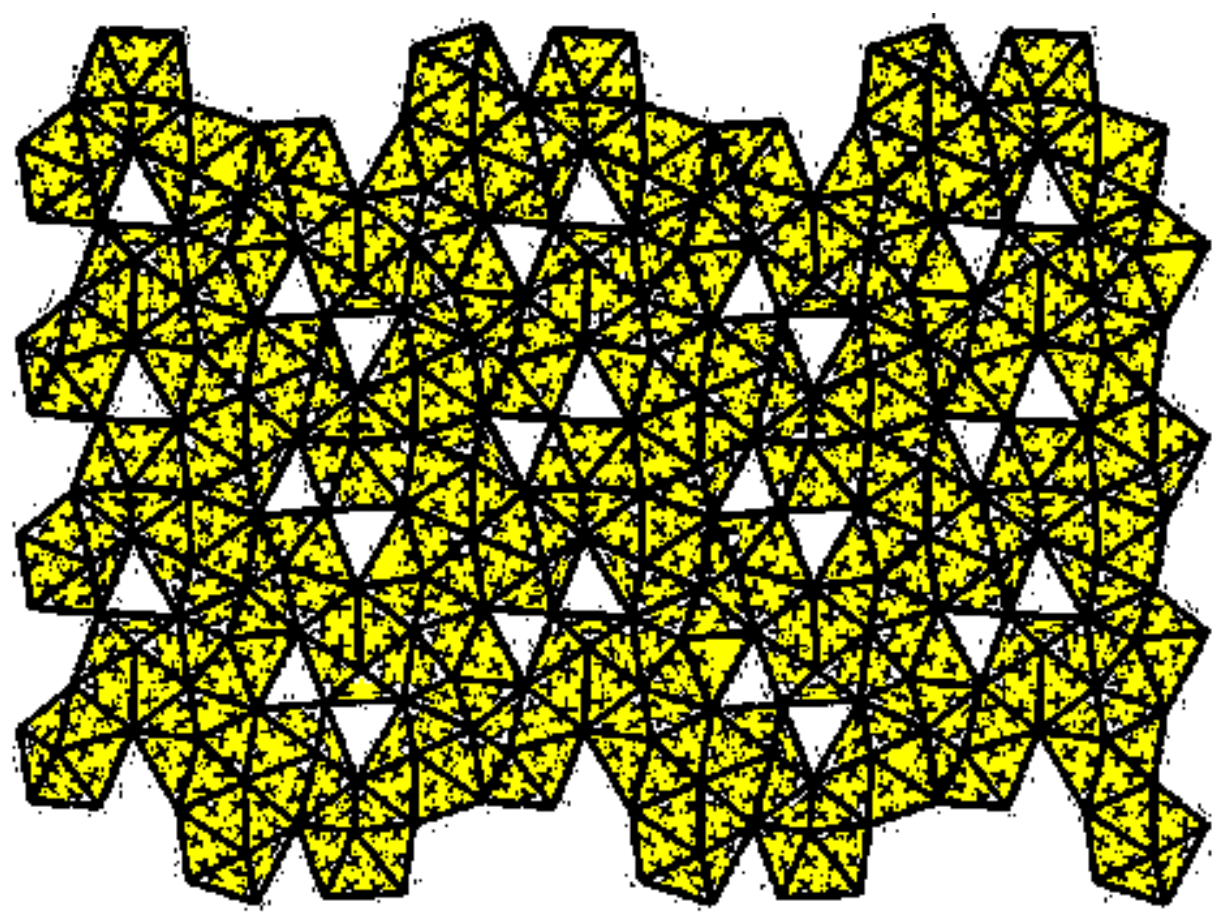

Figure 1.2. Uranyl Hydroxyl Sheet $\left.\left(\mathrm{UO}_{2}\right)_{8} \mathrm{O}_{2}(\mathrm{OH})_{12}\right]\left(\mathrm{H}_{2} \mathrm{O}\right)_{10}$ (adapted from Burns 1999) 


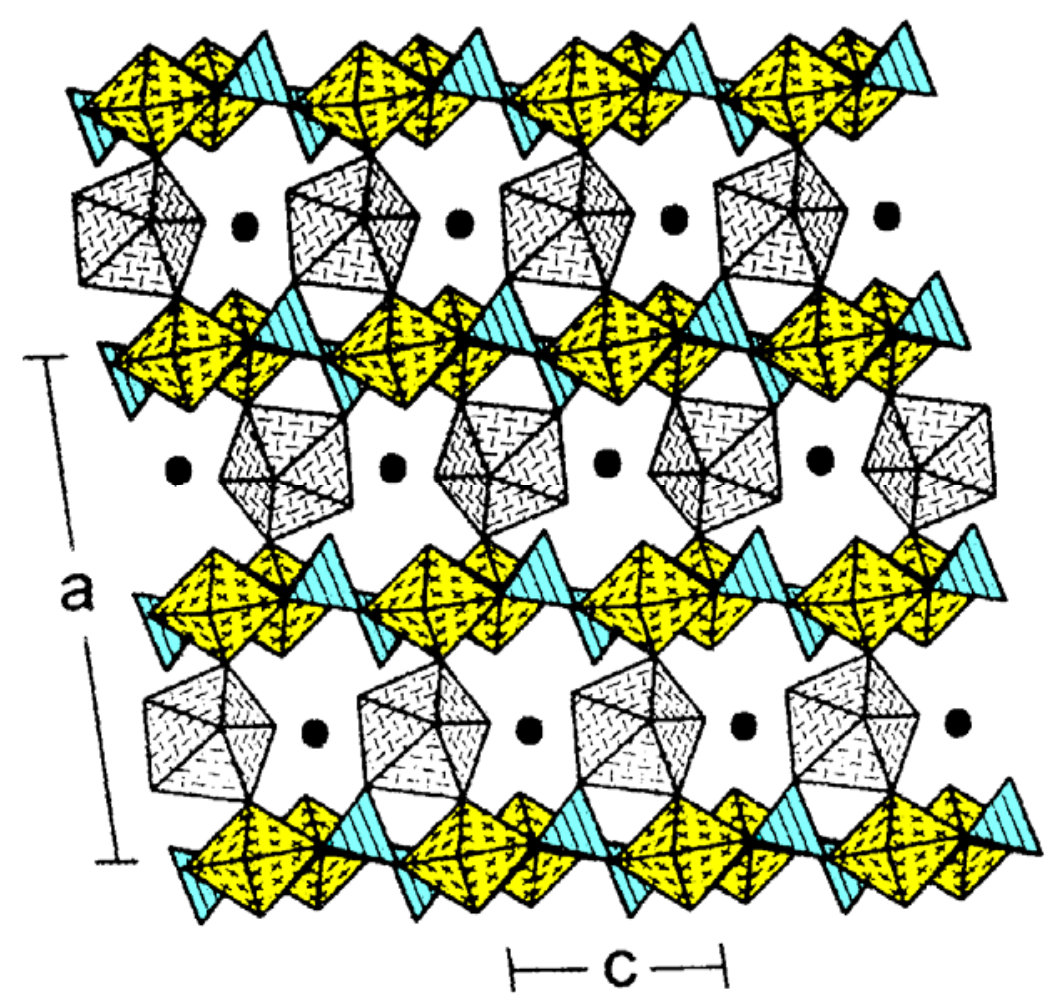

Figure 1.3. Sheet Structure for Uranophane. $\mathrm{Ca}\left[\left(\mathrm{UO}_{2}\right)\left(\mathrm{SiO}_{3} \mathrm{OH}\right)\right]_{2} \cdot 5 \mathrm{H}_{2} \mathrm{O}$. The yellow polyhedra are uranium(VI), the blue tetrahedra are silicate, and the white pentahedra are Calcium(II). (adapted from Burns 1999)

For example, a potential mechanism for reducing radionuclide release to the environment is by incorporation into or sorption onto U(VI) secondary phases that precipitate during SNF alteration (Wronkiewicz et al. 1996). The U(VI) solid phases that form are expected to depend on the nature of the contacting solution and the surface conditions of the SNF. Potential U(VI) solid phases that may be of interest to the repository are listed in Table 1.1, taken from Chen et al. (Chen et al. 1999). The absorption or incorporation of radionuclides onto or into these U(VI) solid phases may slow their release into the surrounding environment because of the lower solubility of these phases. This idea has been studied with various U(VI) solids phases, including uranyl oxy hydroxides and uranyl silicates (Burns 1997); however, a potential $\mathrm{U}(\mathrm{VI})$ solid phase that has received little attention is studtite $\left(\mathrm{UO}_{4}\right)$, a uranyl peroxide. 
Table 1.1. Uranium Minerals Potentially of Interest to the Repository

\begin{tabular}{|c|c|}
\hline Mineral & Formula \\
\hline & $\alpha-\left[\left(\mathrm{UO}_{2}\right)(\mathrm{OH})_{2}\right]$ \\
\hline & $\beta-\left[\left(\mathrm{UO}_{2}\right)(\mathrm{OH})_{2}\right]$ \\
\hline & $\gamma-\left[\left(\mathrm{UO}_{2}\right)(\mathrm{OH})_{2}\right]$ \\
\hline schoepite & {$\left[\left(\mathrm{UO}_{2}\right)_{8} \mathrm{O}_{2}(\mathrm{OH})_{12}\right]\left(\mathrm{H}_{2} \mathrm{O}\right)_{12}$} \\
\hline \multirow[t]{13}{*}{ meta-schoepite } & {$\left[\left(\mathrm{UO}_{2}\right)_{8} \mathrm{O}_{2}(\mathrm{OH})_{12}\right]\left(\mathrm{H}_{2} \mathrm{O}\right)_{10}$} \\
\hline & $\left.\left[\mathrm{UO}_{3}\right)\left(\mathrm{H}_{2} \mathrm{O}\right)_{0.9}\right]$ \\
\hline & $\mathrm{Li}_{2}\left[\left(\mathrm{UO}_{2}\right) \mathrm{O}_{2}\right]$ \\
\hline & $\mathrm{Li}_{4}\left[\left(\mathrm{UO}_{2}\right) \mathrm{O}_{3}\right]$ \\
\hline & $\beta-\mathrm{Na}_{2}\left[\left(\mathrm{UO}_{2}\right) \mathrm{O}_{2}\right]$ \\
\hline & $\mathrm{Na}_{4}\left[\left(\mathrm{UO}_{2}\right) \mathrm{O}_{3}\right.$ \\
\hline & $\mathrm{Na}_{2} \mathrm{U}_{2} \mathrm{O}_{7}$ \\
\hline & $\mathrm{K}_{2} \mathrm{UO}_{4}$ \\
\hline & $\mathrm{K}_{2}\left[\left(\mathrm{UO}_{2}\right) \mathrm{O}_{3}\right]$ \\
\hline & $\mathrm{K}_{2}\left[\left(\mathrm{UO}_{2}\right)_{5} \mathrm{O}_{8}\right]\left(\mathrm{UO}_{2}\right)_{2}$ \\
\hline & $\mathrm{Cs}_{2} \mathrm{UO}_{4}$ \\
\hline & $\mathrm{Cs}_{4} \mathrm{U}_{5} \mathrm{O}_{17}$ \\
\hline & $\mathrm{Rb}_{2} \mathrm{UO}_{4}$ \\
\hline \multirow[t]{9}{*}{ becquerelite } & $\mathrm{Ca}\left[\left(\mathrm{UO}_{2}\right)_{3} \mathrm{O}_{2}(\mathrm{OH})_{3}\right]_{2}\left(\mathrm{H}_{2} \mathrm{O}\right)_{8}$ \\
\hline & $\mathrm{SrUO}_{4}$ \\
\hline & {$\left[\mathrm{Sr}_{3}\left(\mathrm{UO}_{2}\right)_{11} \mathrm{O}_{14}\right]$} \\
\hline & $\mathrm{BaUO}_{4}$ \\
\hline & $\mathrm{BaU}_{2} \mathrm{O}_{7}$ \\
\hline & $\mathrm{Ba}_{3} \mathrm{UO}_{6}$ \\
\hline & $\mathrm{Ba}_{2} \mathrm{MgUO}_{6}$ \\
\hline & $\mathrm{Ba}_{2} \mathrm{CaUO}_{6}$ \\
\hline & $\mathrm{BaSrUO}_{6}$ \\
\hline protasite & $\mathrm{Ba}\left[\left(\mathrm{UO}_{2}\right) \mathrm{O}_{3}(\mathrm{OH})_{2}\right]\left(\mathrm{H}_{2} \mathrm{O}\right)_{3}$ \\
\hline \multirow[t]{3}{*}{ billietite } & $\mathrm{Ba}\left[\left(\mathrm{UO}_{2}\right) \mathrm{O}_{2}(\mathrm{OH})_{3}\right]_{2}\left(\mathrm{H}_{2} \mathrm{O}\right)_{4}$ \\
\hline & $\mathrm{MgUO}_{4}$ \\
\hline & $\mathrm{PbUO}_{4}$ \\
\hline fourmarierite & $\mathrm{Pb}\left[\left(\mathrm{UO}_{2}\right)_{4} \mathrm{O}_{3}(\mathrm{OH})_{4}\right]\left(\mathrm{H}_{2} \mathrm{O}\right)_{4}$ \\
\hline sayrite & $\mathrm{Pb}_{2}\left[\left(\mathrm{UO}_{2}\right)_{5} \mathrm{O}_{6}(\mathrm{OH})_{2}\right]\left(\mathrm{H}_{2} \mathrm{O}\right)_{4}$ \\
\hline curite & $\mathrm{Pb}_{3}\left[\left(\mathrm{UO}_{2}\right)_{8} \mathrm{O}_{8}(\mathrm{OH})_{6}\right]\left(\mathrm{H}_{2} \mathrm{O}\right)_{3}$ \\
\hline$\alpha$-uranophane & $\mathrm{Ca}\left[\left(\mathrm{UO}_{2}\right)\left(\mathrm{SiO}_{2} \mathrm{OH}\right)\right]_{2}\left(\mathrm{H}_{2} \mathrm{O}\right)_{5}$ \\
\hline boltwoodite & $(\mathrm{K}, \mathrm{Na})\left[\left(\mathrm{UO}_{2}\right)\left(\mathrm{SiO}_{3} \mathrm{OH}\right)\right]\left(\mathrm{H}_{2} \mathrm{O}\right)_{1.5}$ \\
\hline cupro-sklodowskite & $\mathrm{Cu}\left[\left(\mathrm{UO}_{2}\right)\left(\mathrm{SiO}_{3} \mathrm{OH}\right)\right]_{2}\left(\mathrm{H}_{2} \mathrm{O}\right)_{6}$ \\
\hline skodowskite & $\mathrm{Mg}\left[\left(\mathrm{UO}_{2}\right)\left(\mathrm{SiO}_{3} \mathrm{OH}\right)\right]_{2}\left(\mathrm{H}_{2} \mathrm{O}\right)_{6}$ \\
\hline
\end{tabular}


Table 1.1 (contd)

\begin{tabular}{|c|c|}
\hline Mineral & Formula \\
\hline kasolite & $\mathrm{Pb}\left[\left(\mathrm{UO}_{2}\right)\left(\mathrm{SiO}_{4}\right)\right]\left(\mathrm{H}_{2} \mathrm{O}\right)$ \\
\hline$\beta$-uranophane & $\left.\mathrm{Ca}\left[\mathrm{UO}_{2}\right)\left(\mathrm{SiO}_{2} \mathrm{OH}\right)\right]_{2}\left(\mathrm{H}_{2} \mathrm{O}\right)_{5}$ \\
\hline soddyite & {$\left[\left(\mathrm{UO}_{2}\right)_{2}\left(\mathrm{SiO}_{4}\right)\right]\left(\mathrm{H}_{2} \mathrm{O}\right)_{2}$} \\
\hline weeksite & $(\mathrm{Na}, \mathrm{K})_{2}\left[\left(\mathrm{UO}_{2}\right)_{2}\left(\mathrm{Si}_{5} \mathrm{O}_{13}\right)\right]\left(\mathrm{H}_{2} \mathrm{O}\right)_{3}$ \\
\hline chernikovite & {$\left[\left(\mathrm{UO}_{2}\right) \mathrm{H}\left(\mathrm{PO}_{4}\right)\right]\left(\mathrm{H}_{2} \mathrm{O}\right)_{4}$} \\
\hline \multirow[t]{4}{*}{ phosphuranylite } & $\mathrm{KCa}\left(\mathrm{H}_{3} \mathrm{O}\right)\left(\mathrm{UO}_{2}\right)\left[\left(\mathrm{UO}_{2}\right)_{4}\left(\mathrm{PO}_{4}\right)_{2} \mathrm{O}_{2}\right]\left(\mathrm{H}_{2} \mathrm{O}\right)_{8}$ \\
\hline & $\mathrm{K}\left[\left(\mathrm{UO}_{2}\right)\left(\mathrm{PO}_{4}\right)\right]\left(\mathrm{D}_{2} \mathrm{O}\right)_{3}$ \\
\hline & $\mathrm{Cs}\left[\left(\mathrm{UO}_{2}\right)\left(\mathrm{PO}_{4}\right)_{3}\right]$ \\
\hline & $\mathrm{Na}_{2}\left[\left(\mathrm{UO}_{2}\right)\left(\mathrm{P}_{2} \mathrm{O}_{7}\right)\right]$ \\
\hline saleeite & $\mathrm{Mg}\left[\left(\mathrm{UO}_{2}\right)\left(\mathrm{PO}_{4}\right)\right]_{2}\left(\mathrm{H}_{2} \mathrm{O}\right)_{10}$ \\
\hline meta-autunite & $\mathrm{Ca}\left[\left(\mathrm{UO}_{2}\right)\left(\mathrm{PO}_{4}\right)\right]_{2}\left(\mathrm{H}_{2} \mathrm{O}\right)_{6}$ \\
\hline \multirow[t]{2}{*}{ meta-uranocircite } & $\mathrm{Ba}\left[\left(\mathrm{UO}_{2}\right)\left(\mathrm{PO}_{4}\right)\right]_{2}\left(\mathrm{H}_{2} \mathrm{O}\right)_{6}$ \\
\hline & $\mathrm{Al}\left[\left(\mathrm{UO}_{2}\right)_{3} \mathrm{O}(\mathrm{OH})\left(\mathrm{PO}_{4}\right)_{2}\right]\left(\mathrm{H}_{2} \mathrm{O}\right)_{7}$ \\
\hline \multirow[t]{2}{*}{ threadgoldite } & $\mathrm{Al}\left[\left(\mathrm{UO}_{2}\right)\left(\mathrm{PO}_{4}\right)\right]_{2}(\mathrm{OH})\left(\mathrm{H}_{2} \mathrm{O}\right)_{8}$ \\
\hline & $\mathrm{K}_{4}\left[\left(\mathrm{UO}_{2}\right)\left(\mathrm{PO}_{4}\right)_{2}\right]$ \\
\hline phurcalite & $\mathrm{Ca}_{2}\left[\left(\mathrm{UO}_{2}\right)_{3}\left(\mathrm{PO}_{4}\right) \mathrm{O}_{2}\right]\left(\mathrm{H}_{2} \mathrm{O}\right)_{7}$ \\
\hline meta-zeunerite & $\mathrm{Cu}\left[\left(\mathrm{UO}_{2}\right)\left(\mathrm{AsO}_{4}\right)\right]_{2}\left(\mathrm{H}_{2} \mathrm{O}\right)_{8}$ \\
\hline \multirow[t]{10}{*}{ abernathyite } & $\mathrm{K}\left[\left(\mathrm{UO}_{2}\right)\left(\mathrm{AsO}_{4}\right)\right]\left(\mathrm{H}_{2} \mathrm{O}\right)_{3}$ \\
\hline & $\mathrm{KH}_{3} \mathrm{O}\left[\left(\mathrm{UO}_{2}\right)\left(\mathrm{AsO}_{4}\right)\right]_{2}\left(\mathrm{H}_{2} \mathrm{O}\right)_{6}$ \\
\hline & $\left(\mathrm{UO}_{2}\right)\left(\mathrm{SO}_{4}\right)\left(\mathrm{H}_{2} \mathrm{O}\right)_{3.5}$ \\
\hline & $\left(\mathrm{UO}_{2}\right)\left(\mathrm{SO}_{4}\right)\left(\mathrm{H}_{2} \mathrm{O}\right)_{2.5}$ \\
\hline & {$\left[\left(\mathrm{UO}_{2}\right)\left(\mathrm{SO}_{4}\right)\left(\mathrm{H}_{2} \mathrm{O}\right)_{2}\right]\left(\mathrm{H}_{2} \mathrm{O}\right)_{3}$} \\
\hline & $\beta-\left(\mathrm{UO}_{2}\right)\left(\mathrm{SO}_{4}\right)$ \\
\hline & $\mathrm{Cs}_{2}\left[\left(\mathrm{UO}_{2}\right)_{2}\left(\mathrm{SO}_{4}\right)_{3}\right]$ \\
\hline & $\mathrm{Mg}\left[\left(\mathrm{UO}_{2}\right)\left(\mathrm{SO}_{4}\right)_{2}\right]\left(\mathrm{H}_{2} \mathrm{O}\right)_{11}$ \\
\hline & {$\left[\mathrm{H}_{2}\left(\mathrm{UO}_{2}\right)\left(\mathrm{SO}_{4}\right)_{2}\right]\left(\mathrm{H}_{2} \mathrm{O}\right)_{5}$} \\
\hline & $\mathrm{K}_{2}\left[\left(\mathrm{UO}_{2}\right)\left(\mathrm{SO}_{4}\right)_{2}\right]\left(\mathrm{H}_{2} \mathrm{O}\right)_{2}$ \\
\hline zippeite & $\mathrm{K}\left[\left(\mathrm{UO}_{2}\right)_{2}\left(\mathrm{SO}_{4}\right)(\mathrm{OH})_{3}\right]\left(\mathrm{H}_{2} \mathrm{O}\right)$ \\
\hline rutherfordine & $\left(\mathrm{UO}_{2}\right)\left(\mathrm{CO}_{3}\right)$ \\
\hline liebigite & $\mathrm{Ca}_{2}\left[\left(\mathrm{UO}_{2}\right)\left(\mathrm{CO}_{3}\right)_{3}\right]\left(\mathrm{H}_{2} \mathrm{O}\right)_{11}$ \\
\hline bayleyite & $\mathrm{Mg}_{2}\left[\left(\mathrm{UO}_{2}\right)\left(\mathrm{CO}_{3}\right)_{3}\right]\left(\mathrm{H}_{2} \mathrm{O}\right)_{18}$ \\
\hline swartzite & $\mathrm{MgCa}\left[\left(\mathrm{UO}_{2}\right)\left(\mathrm{CO}_{3}\right)_{3}\right]\left(\mathrm{H}_{2} \mathrm{O}\right)_{12}$ \\
\hline \multirow[t]{6}{*}{ andersonite } & $\mathrm{Na}_{2} \mathrm{Ca}\left[\left(\mathrm{UO}_{2}\right)\left(\mathrm{CO}_{3}\right)_{3}\right]\left(\mathrm{H}_{2} \mathrm{O}\right)_{5}$ \\
\hline & $\mathrm{Cs}_{4}\left[\left(\mathrm{UO}_{2}\right)\left(\mathrm{CO}_{3}\right)_{3}\left(\mathrm{H}_{2} \mathrm{O}\right)_{6}\right.$ \\
\hline & $\mathrm{Sr}_{2}\left[\left(\mathrm{UO}_{2}\right)\left(\mathrm{CO}_{3}\right)_{3}\left(\mathrm{H}_{2} \mathrm{O}\right)_{6}\right.$ \\
\hline & $\mathrm{Rb}\left[\left(\mathrm{UO}_{2}\right)\left(\mathrm{NO}_{3}\right)_{3}\right]$ \\
\hline & {$\left[\left(\mathrm{UO}_{2}\right)\left(\mathrm{NO}_{3}\right)_{2}\right]\left(\mathrm{H}_{2} \mathrm{O}\right)_{6}$} \\
\hline & {$\left[\left(\mathrm{UO}_{2}\right)\left(\mathrm{NO}_{3}\right)_{2}\right]\left(\mathrm{H}_{2} \mathrm{O}\right)_{3}$} \\
\hline
\end{tabular}


Table 1.1 (contd)

\begin{tabular}{|c|c|}
\hline \multirow[t]{8}{*}{\begin{tabular}{|l|} 
Mineral \\
\end{tabular}} & Formula \\
\hline & {$\left[\left(\mathrm{UO}_{2}\right)\left(\mathrm{NO}_{3}\right)_{2}\right]\left(\mathrm{H}_{2} \mathrm{O}\right)_{2}$} \\
\hline & {$\left[\left(\mathrm{UO}_{2}\right)_{2}(\mathrm{OH})_{2}\left(\mathrm{NO}_{3}\right)_{2}\right]\left(\mathrm{H}_{2} \mathrm{O}\right)_{4}$} \\
\hline & {$\left[\left(\mathrm{UO}_{2}\right)_{3} \mathrm{O}(\mathrm{OH})_{2}\left(\mathrm{H}_{2} \mathrm{O}\right)_{6}\right]\left(\mathrm{NO}_{3}\right)\left(\mathrm{H}_{2} \mathrm{O}\right)_{4}$} \\
\hline & $\mathrm{Na}\left[\left(\mathrm{UO}_{2}\right)\left(\mathrm{BO}_{3}\right)\right]$ \\
\hline & $\mathrm{Li}\left[\left(\mathrm{UO}_{2}\right)\left(\mathrm{BO}_{3}\right)\right]$ \\
\hline & {$\left[\mathrm{Mg}\left(\mathrm{UO}_{2}\right)\left(\mathrm{B}_{2} \mathrm{O}_{5}\right)\right]$} \\
\hline & {$\left[\mathrm{Ca}\left(\mathrm{UO}_{2}\right)_{2}\left(\mathrm{BO}_{3}\right)_{2}\right]$} \\
\hline \multirow[t]{3}{*}{ francevillite } & 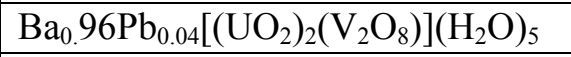 \\
\hline & $\mathrm{Pb}\left[\left(\mathrm{UO}_{2}\right)_{2}\left(\mathrm{~V}_{2} \mathrm{O}_{8}\right)\right]\left(\mathrm{H}_{2} \mathrm{O}\right)_{5}$ \\
\hline & $\mathrm{K}_{2}\left[\left(\mathrm{UO}_{2}\right)_{2}\left(\mathrm{~V}_{2} \mathrm{O}_{8}\right)\right]$ \\
\hline \multirow[t]{4}{*}{ sengierite } & $\mathrm{Cu}_{2}\left[\left(\mathrm{UO}_{2}\right)_{2}\left(\mathrm{~V}_{2} \mathrm{O}_{8}\right)(\mathrm{OH})_{2}\right]\left(\mathrm{H}_{2} \mathrm{O}\right)_{6}$ \\
\hline & $\mathrm{Ni}\left[\left(\mathrm{UO}_{2}\right)_{2}\left(\mathrm{~V}_{2} \mathrm{O}_{8}\right)\right]\left(\mathrm{H}_{2} \mathrm{O}\right)_{4}$ \\
\hline & $\mathrm{Cs}_{2}\left[\left(\mathrm{UO}_{2}\right)_{2}\left(\mathrm{~V}_{2} \mathrm{O}_{8}\right)\right]$ \\
\hline & $\mathrm{Cs}_{2}\left[\left(\mathrm{UO}_{2}\right)_{2}\left(\mathrm{Nb}_{2} \mathrm{O}_{8}\right)\right]$ \\
\hline \multirow[t]{2}{*}{ iriginite } & {$\left[\left(\mathrm{UO}_{2}\right)\left(\mathrm{MoO}_{3} \mathrm{OH}\right)_{2}\left(\mathrm{H}_{2} \mathrm{O}\right)\right]\left(\mathrm{H}_{2} \mathrm{O}\right)$} \\
\hline & {$\left[\mathrm{Ca}\left(\mathrm{UO}_{2}\right) \mathrm{Mo}_{4} \mathrm{O}_{14}\right]$} \\
\hline \multirow[t]{5}{*}{ umohoite } & {$\left[\left(\mathrm{UO}_{2}\right)\left(\mathrm{MoO}_{4}\right)\right]\left(\mathrm{H}_{2} \mathrm{O}\right)_{4}$} \\
\hline & $\alpha-\left(\mathrm{UO}_{2}\right)\left(\mathrm{MoO}_{4}\right)\left(\mathrm{H}_{2} \mathrm{O}\right)_{2}$ \\
\hline & $\mathrm{Sr}\left(\mathrm{UO}_{2}\right)_{6}\left(\mathrm{MoO}_{4}\right)_{7}\left(\mathrm{H}_{2} \mathrm{O}\right)_{15}$ \\
\hline & $\mathrm{Ba}\left(\mathrm{UO}_{2}\right)_{3}\left(\mathrm{MoO}_{4}\right)_{4}\left(\mathrm{H}_{2} \mathrm{O}\right)_{4}$ \\
\hline & $\mathrm{Mg}\left(\mathrm{UO}_{2}\right)_{3}\left(\mathrm{MoO}_{4}\right)_{4}\left(\mathrm{H}_{2} \mathrm{O}\right)_{8}$ \\
\hline
\end{tabular}

\subsection{How Studtite is Formed}

The two accepted forms of uranyl peroxide are studtite $\left(\mathrm{UO}_{4} 4 \mathrm{H}_{2} \mathrm{O}\right)$ and meta studtite $\left(\mathrm{UO}_{4} \cdot 2 \mathrm{H}_{2} \mathrm{O}\right)$ (Leininger et al. 1985). Each uranyl center is square bipyramidal, with a bidentate peroxide ligand as shown in Figure 1.4. The waters (two or four) are in the inner layer of the uranyl sheets; two are presumed to be structural, and the other two are presumed to be waters of hydration. 


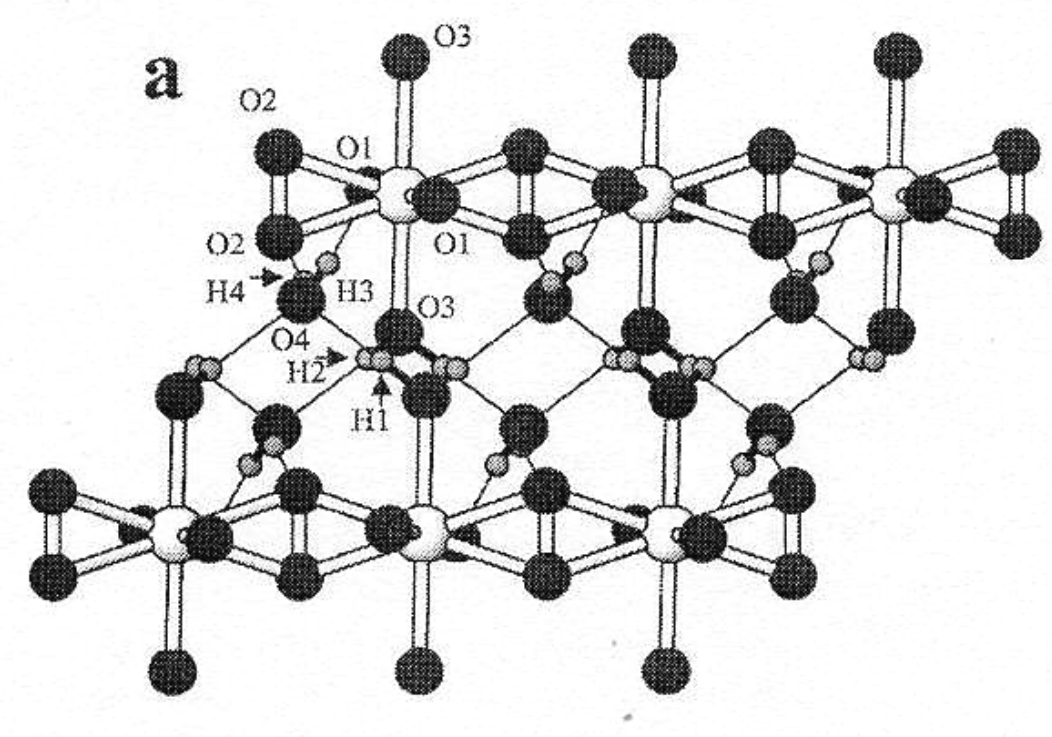

Figure 1.4. Structure of Studtite with its Waters of Hydration (Burns and Hughes 2003)

In the early corrosion of SNF, it has been presumed that the uranyl oxy hydroxides will be the first phases formed (Wronkiewicz 1992). However, several studies have indicated that an early U(VI) phase that forms from SNF may be the uranyl peroxides, studtite, or meta studtite (Abrefah et al. 1998; McNamara et al. 2002). The SEM and XRD analysis of spent fuel from Hanford's N-Reactor (uranium metal) that has been exposed to water indicated that the cladding exterior is coated with the U(VI) peroxide studtite with no evidence of schoepite. Because of its relatively low burnup, the N-Reactor fuel radiation field is much less than those from commercial spent nuclear fuel with an equivalent decay time. In the fuel/clad gap of the N-fuel, where unreacted uranium metal serves as a large sink for oxidants to produce $\mathrm{UO}_{2+\mathrm{x}}$, only schoepite was observed (Abrefah et al. 1998). McNamara et al. (2002) first observed schoepite on the surface of commercial spent fuel reacted in deionized water. After approximately 1.5 years, the schoepite had been completely replaced with studtite. This observation indicates that in the presence of a radiation field that is producing peroxide and many other species (Allen 1961; Draganic and Draganic 1971) (e.g., $\mathrm{OH}, \mathrm{O}_{2}, \mathrm{H}_{2}, \mathrm{e}_{(\mathrm{aq})}^{-}$), the formation of studtite is favored over other uranium oxyhydrates when the peroxide concentration is large enough and when other peroxidescavenging mechanisms are limited. Studtite formation is believed to form via an oxidative dissolution followed by precipitation as the uranyl peroxide. Sattonnay et al. (Sattonnay et al. 2001) have observed the formation of studtite on the surface of $\mathrm{UO}_{2}$ in the presence of an alpha radiation field that generated millimolar amounts of peroxide in the $\mathrm{UO}_{2}$ contact solution.

It is known that uranium peroxides precipitate from solution when uranyl ions contact peroxide (Gmelin Handbook 1984). This mechanism has also been observed in natural uraninite deposits where uranium peroxides formed the minerals studtite and meta-studtite close to uranium orebodies under highly oxidizing conditions. The observation of these phases in million-year-old deposits suggests their longterm stability. 
Unirradiated $\mathrm{UO}_{2}$ that is exposed to water does not readily form the uranyl peroxide (because of lack of peroxide from the radiation field) but rather forms various uranyl oxy hydroxides, such as schoepite (Burns and Finch 1999). Irradiated fuel (SNF) can generate enough radiolysis to produce the peroxide necessary to form studtite (Abrefah et al. 1998; McNamara et al. 2002; Sattonnay et al. 2001; Shoesmith 2000). The use of unirradiated fuel as a surrogate for spent fuel without an appropriate applied radiation field or appropriate fuel surface area to water volume ration (for $\alpha$-radiolysis from uranium decay) will preclude the formation of a potentially important $\mathrm{U}(\mathrm{VI})$ phase.

Amme discussed the chemical conditions necessary for the formation of studtite or schoepite (Amme 2002). The effect of hydrogen peroxide on the dissolution of nuclear fuel in water was studied to determine the concentration of hydrogen peroxide necessary to form studtite. Amme also examined the phases formed in groundwater, where various constituents scavenge peroxide, thus inhibiting the formation of the uranyl peroxide. The hydrogen peroxide concentration is a major variable that defines which U(VI) phase might form. If there are chemical components that scavenge hydrogen peroxide from solution, then even in the presence of a high radiation field, schoepite forms. The mineral oxide surface can also affect the radiolysis product generation mechanisms. The localized radiolysis-produced hydrogen peroxide formed by a radiation field may be important (Christensen et al. 1994; Sunder 1993), and a systematic study is needed to understand the radiolysis conditions necessary for the formation of high-peroxide concentrations (Sunder et al. 1992).

If studtite forms during the corrosion of SNF and if it exhibits long-term stability as observed (Burns 2003), the capability of the uranyl peroxide to incorporate other radionuclides may be beneficial to repository performance assessments. The chain structure that is believed to exist in studtite may be capable of incorporating key radionuclides (e.g., $\mathrm{Np}$ ) and thus retard their migration. Sheet structure is common for U(VI) solid phases (Burns et al. 1997). The exact crystal structure of the uranyl peroxides has been verified by single crystal x-ray diffraction (Burns 2003). In addition, some insight on its capability to incorporate radionuclides can be obtained from thermodynamic and structural considerations. Initial results by McNamara et al. indicate that other radionuclides are associated with the studtite structure (McNamara 2004).

\subsection{Incorporation of Radionuclides into Studtite}

Incorporation mechanisms of actinide elements into the structures of U(VI) phases during the corrosion of SNF have been proposed by Burns et al. (Burns et al. 1997). The three proposed methods that actinide elements can substitute into the U(VI) sheet structure are:

1. Substitution of $U(V I)$ by actinides within the sheet structure, with appropriate charge-balancing when required.

2. Substitution for cations other than U(VI), either within the sheet or interlayer, together with appropriate charge-balancing substitutions as necessary.

3. Occupation of vacant sites by actinides, either within the sheet or interlayer, together with appropriate charge-balancing substitutions.

The influence of these mechanisms for incorporating radionuclides into the structure of studtite will be examined. 


\subsection{Incorporation of $\mathrm{Np}^{5+}, \mathrm{Np}^{6+}, \mathrm{Pu}^{5+}$, and $\mathrm{Pu}^{6+}$ into Studtite}

$\mathrm{NpO}_{2}{ }^{+}$is a dioxo cation with a structure very similar to the uranyl cation with linear oxygens approximately $0.181 \mathrm{~nm}$ in length (Burns et al. 1997). They both can be coordinated by four, five, and six anions, forming square, pentagonal, and hexagonal bipyramids, respectively. Typically, oxygen ligands coordinated on the equatorial plane will be about $0.01 \mathrm{~nm}$ longer than the same ligands in the uranyl cation (Burns et al. 1997). The $\mathrm{PuO}_{2}{ }^{+}$cation is the linear dioxo cation similar to $\mathrm{NpO}_{2}{ }^{+}$but with a slightly longer plutonyl oxygen at $0.194 \mathrm{~nm}$. The $\mathrm{PuO}_{2}{ }^{2+}$ cation has the linear oxygens at about $0.190 \mathrm{~nm}$ (Burns et al. 1997). The $\mathrm{NpO}_{2}{ }^{2+}$ cation is similar to the uranyl cation in size, shape, and charge. All four of these cations can have the same polyhedra as the uranyl cation, which allows them to substitute for the $\mathrm{UO}_{2}{ }^{2+}$ cation in studtite.

Burns et al. suggest that incorporation of $\mathrm{Np}(\mathrm{V})$ and/or $\mathrm{Pu}(\mathrm{V})$ may have important ramifications in the crystal structure of the U(VI) solid phase because of the lower bond-valence contributions of the oxygen atoms of the linear oxygens (Burns et al. 1997). Unlike the uranyl cation, which has the bondvalence requirements nearly satisfied by the $\mathrm{U}=\mathrm{O}$ bond, the $\mathrm{Np}(\mathrm{V})$ and $\mathrm{Pu}(\mathrm{V})$ cations require additional bonding. This may come from hydrogen bonding from the interlayer. Alternately, the bond valence can be satisfied by the charge-balance replacements in the interlayer in the interlayer in the form of other incorporated radionuclides.

The similar polyhedra of $\mathrm{Np}(\mathrm{V}), \mathrm{Np}(\mathrm{VI}), \mathrm{Pu}(\mathrm{V})$, and $\mathrm{Pu}(\mathrm{VI})$ and the possibility of charge-balance mechanisms suggest that these cations can substitute for U(VI) in the sheet structure of studtite.

\subsection{Incorporation of $\mathrm{An}^{4+}$ and $\mathrm{An}^{3+}$ Cations into Studtite}

The +3 and +4 actinides of primary interest to a repository are $\mathrm{Np}^{4+}, \mathrm{Pu}^{4+}, \mathrm{Pu}^{3+}, \mathrm{Am}^{3+}$, and $\mathrm{Cm}^{3+}$. These cations tend to form regular polyhedra coordinated by six or eight anions and have similar bond lengths as $\mathrm{U}^{4+}$ (Grambow et al. 1999). There are two probable places for these ions to incorporate into the structure of studtite: in the chain to replace $\mathrm{U}^{6+}$ or in the inner layer.

It is likely that the An(IV) cations could be substituted for the $\mathrm{Ur}_{4}$ polyhedra of U(VI) in studtite because of the capability of the An(IV) to form similar polyhedra. It is also likely that the An(IV) cations will bring with them more waters of hydration, which the studtite structure can accommodate in the inner layer. There are two possible methods for appropriate charge-balancing mechanisms, the above described exchange of $\mathrm{O}_{2}{ }^{2-}$ with $\mathrm{HO}_{2}{ }^{-}$and the possibility of other cations (stable cations, rare earth elements (REE) or $\mathrm{An}^{3+}$ ) incorporated into the interlayer. The charge difference between the U(VI) and An(IV) could be balanced by adding interlayer cations as well as the structural water and water of hydration. A combination of these two charge-balance mechanisms may be present in the same solid phase.

Burns et al. suggested that An(III) cations will be unable to substitute for U(VI) in the sheet structure of schoepite because of the disparity of charge, but rather can be incorporated in the inner layer. A similar argument can be used for studtite. Adding An(III) ions in the inner layer should occur if local charge balancing is possible, and the size difference is not too large. The charge balancing should proceed by a similar mechanism as described for U(VI) and (IV) cations. 


\subsection{Experimental Evidence for Association of $\mathrm{Np}$ in U(VI) Minerals}

The formation of schoepite from the corrosion of $\mathrm{UO}_{2}$ has been observed and is the presumed first $\mathrm{U}(\mathrm{VI})$ phase to form from oxidative dissolution. The formation of studtite may occur directly from SNF or form a secondary phase after the formation of schoepite. Regardless of the order of formation of the $\mathrm{U}(\mathrm{VI})$ solid phases, the incorporation and retention of radionuclides by the U(VI) solid phase is critical information for the models used in the license application of the Yucca Mountain repository.

Although Wruck et al. did not find evidence of incorporation into schoepite (Wruck et al. 1999), their work suggests that $\mathrm{Np}$ was sorbed onto the schoepite. The lack of incorporation into schoepite was also observed by Finch et al. (Finch 2002; Finch et al. 2002). These new studies by Finch et. al. exposed Npdoped $\mathrm{U}_{3} \mathrm{O}_{8}$ to water to form schoepite. The schoepite did not incorporate significant amounts of $\mathrm{Np}$, but rather $\mathrm{NpO}_{2}$ was observed. These experiments suggest that the $\mathrm{Np}$ may not incorporate into U(VI) oxy hydroxides to an extent significant to retard the release of $\mathrm{Np}$ from corroded $\mathrm{UO}_{2}$. The precipitation of $\mathrm{NpO}_{2}$ indicates that the neptunium oxide solid phase may control the long-term solubility under repository conditions.

Burns et al. recently reported incorporation into uranophane and Na-compreignacite (Burns 2004). In this paper, it was reported that very little neptunium associated with meta-schoepite and $\beta-\left(\mathrm{UO}_{2}\right)(\mathrm{OH})_{2}$, which is consistent with previous reported data and data presented in this report. Burns also describes a convincing argument as to why these selected minerals associate or do not associate neptunium.

\subsection{Experiments Presented in this Report}

Four uranium mineral phases were studied in the initial tests at PNNL: meta-schoepite, uranophane, meta-studtite, and sodium boltwoodite. These phases are the primary secondary phases expected to form based on interactions of spent nuclear fuel (SNF) with the local environment (Finch 1992). These phases were synthesized in the presence of neptunium(V). The resulting solids were characterized by $\mathrm{x}$-ray diffraction (XRD), gamma energy analysis (GEA), scanning electron microscopy (SEM), transmission electron microscopy (TEM), and electron energy loss spectroscopy (EELS). The EELS data and discussion of potential incorporation in uranyl phases is described in a recent report by Buck (Buck 2003). Solutions were analyzed by GEA and kinetic phosphorescence analysis (KPA). Using these methods, the fate of the neptunium was determined in these synthetic experiments. 


\subsection{Experimental Methods}

Synthesis methods were developed for the formation of the uranium solids. The following is a detailed description of the methods.

\subsection{Synthesis of Meta-Schoepite}

1. Three solutions of sodium hydroxide at $2.0 \mathrm{M}, 1.0 \mathrm{M}$, and $0.25 \mathrm{M}$ were prepared. Sodium hydroxide pellets were added to deionized water (DIW) to prepare these solutions.

2. The appropriate amount of uranyl acetate was measured into a centrifuge vial. The exact weight of the uranyl acetate was recorded in the laboratory record book (LRB). Dilute acid ( $\approx \mathrm{pH} 2$ with nitric acid) was added to the centrifuge vial. The capped vial was agitated until the solid was dissolved. The solution was yellow, indicating U(VI) in solution.

3. The appropriate amount of neptunium(V) was added to the vial to make a solution that was $0.5,1.0$, or $2.0 \mathrm{~mol}$ percent neptunium, compared to the amount of uranium present. The neptunium was in $0.1 \mathrm{M} \mathrm{HNO}_{3}$ and was confirmed to be $\mathrm{Np}(\mathrm{V})$ by UV-Vis and liquid scintillation counting (LSC). The vial was well mixed before proceeding to ensure a homogenous mixture.

4. A calibrated $\mathrm{pH}$ electrode was placed into the solution in the vial. The $\mathrm{pH}$ was typically below $\mathrm{pH} 2$, depending on how much acid was added with the neptunium. The starting $\mathrm{pH}$ was recorded in the LRB.

5. Sodium hydroxide was added to the vial to raise the $\mathrm{pH}$ to approximately 5.5. One of the samples was accidentally raised to a $\mathrm{pH}$ of 10.4. The sodium hydroxide solutions were added drop wise, with adequate mixing of the solution between additions to ensure that the $\mathrm{pH}$ reading was representative of the entire solution. Solids appeared to precipitate in the vial as the $\mathrm{pH}$ approached 5.5. The solution at 10.4 was colorless with large amounts of solids in the bottom of the vial. The final $\mathrm{pH}$ and time were recorded in the LRB.

6. The vials were left overnight or over the weekend before proceeding. This was to allow time for more solids to precipitate from solution.

7. The next work day, the vials had solids in the bottom, and the solution was slightly yellow. The $\mathrm{pH}$ of all of the solutions was measured with the $\mathrm{pH}$ electrode after mixing the liquid for homogeneity. Precipitation of the meta-schoepite solid resulted in lowering the $\mathrm{pH}$ approximately $1 \mathrm{pH}$ unit to 4.5 to 4.6.

8. Each vial was centrifuged at maximum for 10 minutes to pelletize the solids at the bottom of the vial. The solutions were decanted from the solids into a scintillation vial. Uranium and neptunium concentrations were measured in this solution by KPA and GEA, respectively, following filtration through a $0.45-\mu \mathrm{m}$ filter.

9. Thirty $\mathrm{mL}$ of DIW at $\mathrm{pH} 7$ at room temperature was added to each vial. The solutions were agitated to suspend the solids in the solution for 5 minutes. 
10. Steps 8 and 9 were repeated twice more.

11. Each vial was centrifuged once more and decanted into a labeled centrifuge vial. The solids were allowed to dry in air at room temperature.

12. The solids were transferred to a glass scintillation vial for storage. The solids were then used for further characterization.

\subsection{Synthesis of Meta-Studtite}

1. Direct synthesis of meta-studtite

1.1. Steps 1 through 4 of the meta-schoepite synthesis were followed.

1.2. Fifteen $\mathrm{mL}$ of $30 \%$ hydrogen peroxide was added to each solution. This was done slowly and with great care. Gas was generated during this process, and some frothing occurred.

1.3. Sodium hydroxide was added to each vial to raise the $\mathrm{pH}$ to the desired $\mathrm{pH}$ of 5.5. The sodium hydroxide solutions were added drop wise with adequate mixing of the solution between additions to ensure that the $\mathrm{pH}$ reading was representative of the entire solution.

1.4. Steps 6 through 12 of the meta-schoepite synthesis were followed.

2. Indirect synthesis of meta-studtite (via meta-schoepite)

2.1. Steps 1 through 7 of the meta-schoepite synthesis were followed.

2.2. Step 1.2 of the direct meta-studtite synthesis was next.

2.3. The samples were allowed to sit overnight.

2.4. The $\mathrm{pH}$ was measured and recorded in the LRB.

2.5. Steps 8 through 12 of the meta-schoepite synthesis were followed.

\subsection{Synthesis of Uranophane}

1. Step 1 of the meta-schoepite synthesis was followed.

2. The appropriate amounts of uranyl acetate, sodium meta-silicate, and calcium acetate were measured into polyethylene tubes for reaction and then transferred to a Teflon ${ }^{\circledR}$ beaker of the Parr bomb to achieve a higher degree of crystallinity. The mass was recorded in the LRB.

3. Steps 3 through 5 of the meta-schoepite synthesis were followed, except the $\mathrm{pH}$ was raised to 10 .

4. The Parr bombs were sealed and placed in a heating oven at $130^{\circ} \mathrm{C}$ for one week.

5. Steps 4,8 and 9 of the meta-schoepite synthesis were followed with the exception that boiling DIW was used instead of room-temperature DIW. 


\subsection{Synthesis of Sodium Boltwoodite}

1. Steps 1 and 2 of the meta-schoepite synthesis were followed.

2. Steps 3 through 5 of the meta-schoepite synthesis were followed, except the $\mathrm{pH}$ was raised to 10 within the Teflon beaker of a Parr bomb.

3. Steps 4 and 5 of the uranophane synthesis were followed.

$\mathrm{Al}_{2} \mathrm{O}_{3}$ was added to each sample as an internal standard for XRD analysis. GEA analysis used an HPGe detector with multi-line energy and efficiency calibration. 


\subsection{Results and Discussion}

This section presents the results of testing meta-schoepite, meta-studtite, uranophane, and sodium boltwoodite and discusses the overall trends in neptunium incorporation.

\subsection{Meta-Schoepite Results}

Two different sets of meta-schoepite samples were synthesized. The first set contained eight samples of meta-schoepite with various amounts of neptunium present. Two of these samples were used for further tests by converting them to meta-studtite with the addition of peroxide. The second set varied the amount of $\mathrm{Np}$ in the synthesis and the $\mathrm{pH}$ range. The data from the first set of tests are presented in Table 3.1 and Table 3.2. Two representative XRD patterns of the meta-schoepite samples are shown in Figure 3.1. The data for the second set is presented in Table 3.3.

Several important trends can be seen in these data. At low pH (5.5 or lower), there is very little neptunium associated with the solid. For two samples, the amount of neptunium associated with the solid was below the detection limit of the method. The amount of neptunium in solution in contact with the meta-schoepite is high (approximately the amount added), and the solubility is not controlled by the solid phase. The mol percent of neptunium does not seem to affect the solution concentration, which is further indication that all the neptunium is in solution rather than associated with the solid.

Table 3.1. First Set of Radiochemical Data from Initial Meta-Schoepite Tests at Various Neptunium Concentrations

\begin{tabular}{|c|c|c|c|c|}
\hline "Meta-Schoepite & 4-18-03A & 4-18-03B & 4-18-03C & 4-18-03D \\
\hline pH & 4.6 & 10.4 & 4.6 & 4.5 \\
\hline Initial Mol \% Np & 2 & 1 & 0.5 & 0 \\
\hline [U] sol'n & $0.785 \mathrm{mM}$ & $3.68 \mathrm{E}-4 \mathrm{mM}$ & $0.826 \mathrm{mM}$ & $1.058 \mathrm{mM}$ \\
\hline [Np] solid ${ }^{(\mathrm{a})}$ & $48 \mathrm{ppm}$ & $3400 \mathrm{ppm}$ & $<3.6 \mathrm{ppm}$ & \\
\hline [Np] sol'n ${ }^{(b)}$ & $2.045 \mathrm{E}-4 \mathrm{M}$ & $2.0 \mathrm{E}-7 \mathrm{M}$ & $5.8 \mathrm{E}-5 \mathrm{M}$ & \\
\hline \% Np in sol'n & 68 & 0.1 & 77 & \\
\hline
\end{tabular}


Table 3.2. Radiochemical Data from Meta-Schoepite Tests for Transformation to Studtite

\begin{tabular}{|c|c|c|c|c|}
\hline Meta-Schoepite & 4-30-03C & 4-30-03D & 4-30-03E & 4-30-03F \\
\hline pH & 5.5 & 5.5 & 5.5 & 5.5 \\
\hline Initial Mol \% Np & 2 & 2 & 0 & 0 \\
\hline [U] sol'n & Not measured & To Studtite & To Studtite & Not measured \\
\hline [Np] solid ${ }^{(a)}$ & $<10 \mathrm{ppm}$ & & & \\
\hline [Np] sol'n ${ }^{(b)}$ & $1.47 \mathrm{E}-4 \mathrm{M}^{(\mathrm{a})}$ & & & \\
\hline
\end{tabular}

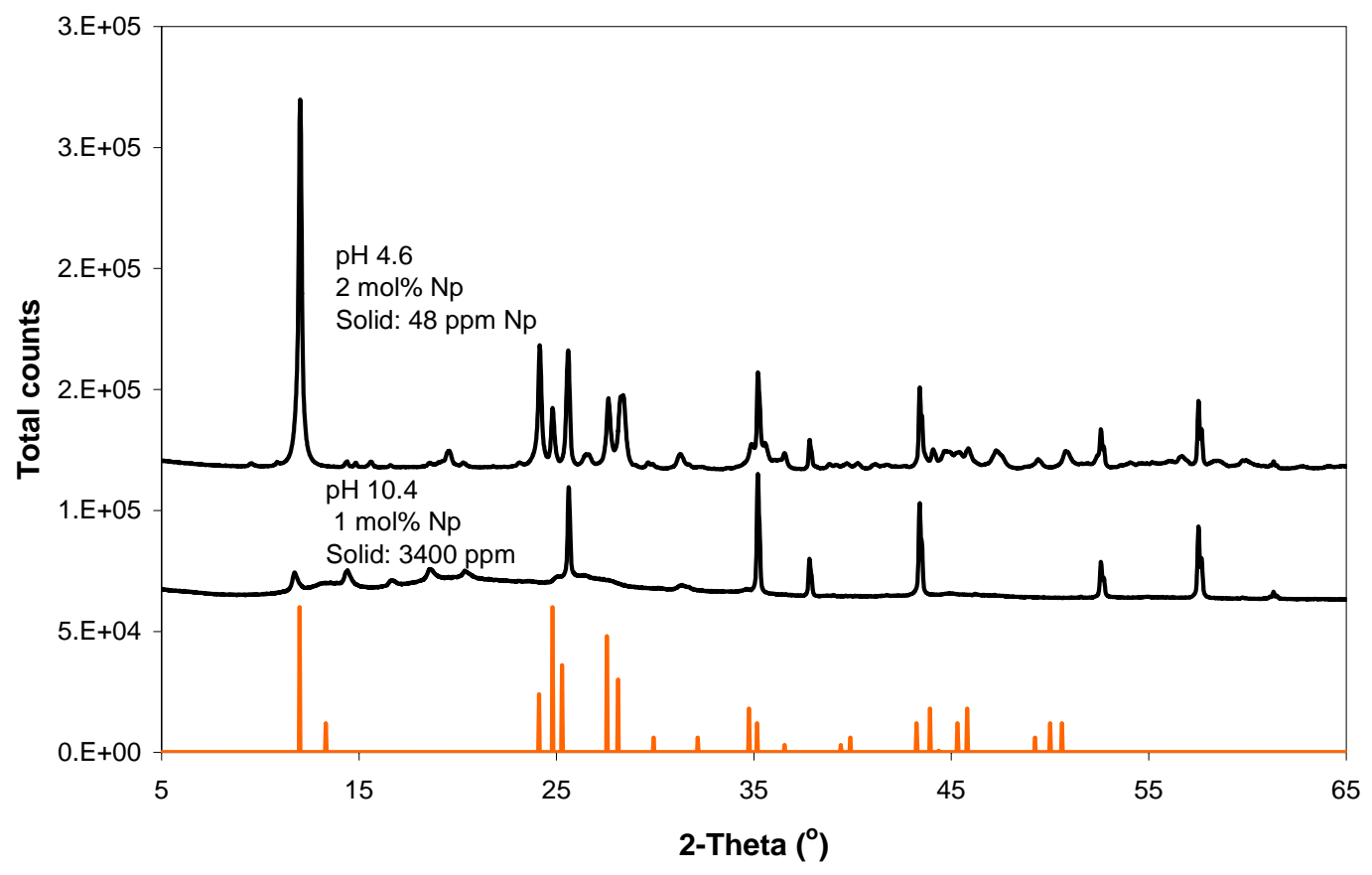

Figure 3.1. XRD Patterns of Two Samples from Meta-Schoepite Synthesis (4-18-03A and 4-18-03B)

Table 3.3. Second Set Test Matrix, Meta-schoepite

\begin{tabular}{|c|c|c|c|c|c|c|c||}
\hline \multirow{2}{*}{ mL U } & M1 & M2 & M3 & M4 & M5 & M6 & M7 \\
\cline { 2 - 8 } & 30 & 30 & 30 & 30 & 30 & 30 & 30 \\
\hline Initial mol \% Np & 2 & 1 & 0.5 & 0 & 1 & 1 & 1 \\
\hline mol Np added & $6.00 \mathrm{E}-06$ & $3.00 \mathrm{E}-06$ & $1.50 \mathrm{E}-06$ & $0.00 \mathrm{E}+00$ & $3.00 \mathrm{E}-06$ & $3.00 \mathrm{E}-06$ & $3.00 \mathrm{E}-06$ \\
\hline$\mu$ L Np added & 723.05 & 361.52 & 180.76 & 0 & 361.52 & 361.52 & 361.52 \\
\hline Final pH & 5.5 & 5.5 & 5.5 & 5.5 & 4.5 & 6.5 & 8.5 \\
\hline
\end{tabular}


One of the meta-schoepite samples (4-18-03B) was synthesized at $\mathrm{pH} 10.4$. This sample indicated that most of the neptunium was associated with the solid phase, with less than $0.1 \%$ still in solution. However, XRD indicates that the structure is somewhat different from meta-schoepite, and the phase was not unambiguously identified, but it is likely a sodium uranyl oxyhydroxide phase. There are three main possibilities for the placement of the neptunium in this sample.

1. The neptunium precipitated as a separate hydroxide phase and was centrifuged out with the uranium.

2. The neptunium is sorbed to the surface of the meta-schoepite (or sodium uranyl oxyhydroxide phase).

3. The neptunium is incorporated/co-precipitated into/with the structure of the meta-schoepite (or sodium uranyl oxyhydroxide phase).

\subsubsection{SEM and EDS Data for Sample 4-18-03B}

Figure 3.1 indicates that this sample is much less crystalline (lower peak intensities and broad peak withed) than the other meta-schoepite samples. The XRD reflections indicate the presence of metaschoepite. The decrease in crystalinity is consistent with previous experiments with uranophane that is doped with other ions besides calcium (e.g., europium, barium, cadmium) and also shows a decrease in crystallinity in the XRD pattern.

Figure 3.2 includes six SEM images of the solid phase from 4-18-03B. These images are representative of the sample. All images indicate the same general morphology. No large independent crystals were found.

Figure 3.3 is the energy dispersive spectroscopy (EDS) spectrum of one of the particles. 137 EDS spectra were obtained of many different particles in an attempt to identify a neptunium-only solid phase. All of the EDS spectra were identical to Figure 3.3, indicating that neptunium did not precipitate as a large $(>1 \mu \mathrm{m})$ particle.

The second set of meta-schoepite synthetic experiments involved an additional aspect that differs from the first set. All fractions of the synthesis were counted to obtain a mass balance for ${ }^{237} \mathrm{~Np}$. This allows for a better indication of the neptunium partitioning. In addition, the $\mathrm{pH}$ range was varied from 4.5 to 8.5 in an attempt to probe the $\mathrm{pH}$ dependence of neptunium partitioning. 

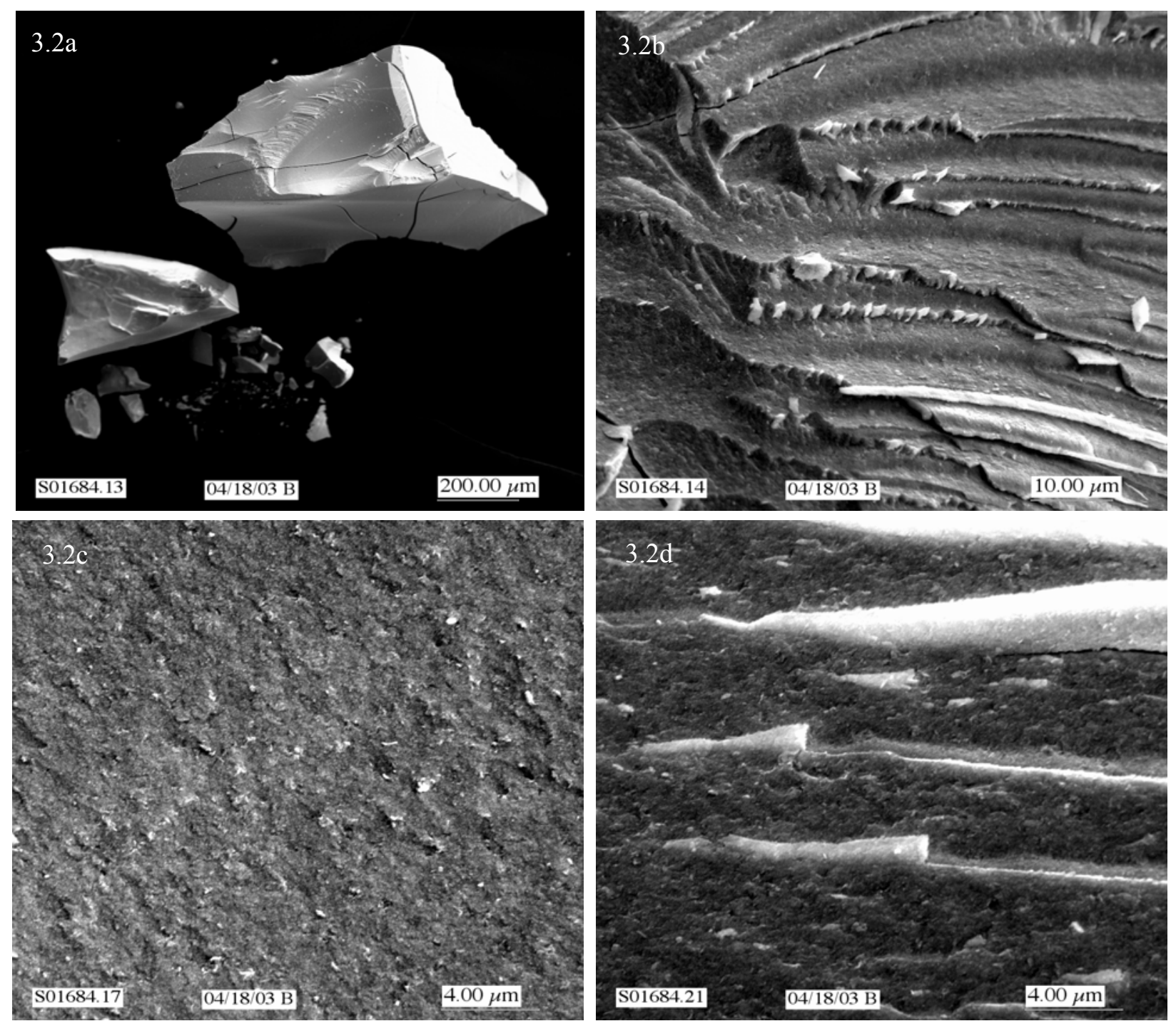

Figure 3.2. SEM Images of 4-18-03B (1 mol \% Np, pH 10.4) 


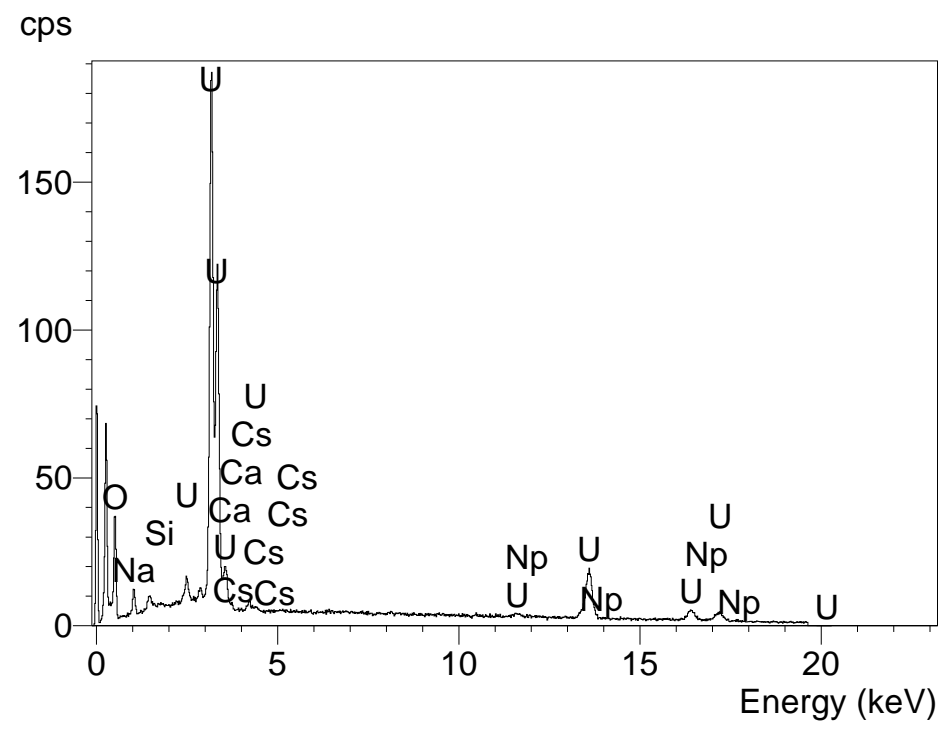

Figure 3.3. EDS Spectrum of 4-18-03B (1 mol \% Np, pH 10.4)

\subsubsection{XRD Data for Samples M1 through M4}

The XRD patterns were carefully examined to look for changes in peak position, intensity, and width as the amount of neptunium and $\mathrm{pH}$ was varied. Figure 3.4 and Figure 3.5 show the 2-mol percent (M1) XRD pattern. In direct comparison, Figure 3.6 and Figure 3.7 is the control sample (M4) that does not contain neptunium. The changes in the spectra are minor and indicate that the structures of the minerals are similar if not identical.

The calculated lattice parameters for the various samples are listed in Table 3.4. These parameters were obtained by fitting the XRD pattern to the meta-schoepite standard. There is no discernable trend in the parameters with neptunium concentration. Sample M1 gives slightly different lattice parameters; however, this is unlikely due to neptunium because there is very little neptunium associated with the solid. It is possible that a minor amount of neptunium is associated with the solid that is causing this shift in lattice parameters; however, there are no other corroborating data for this association. 


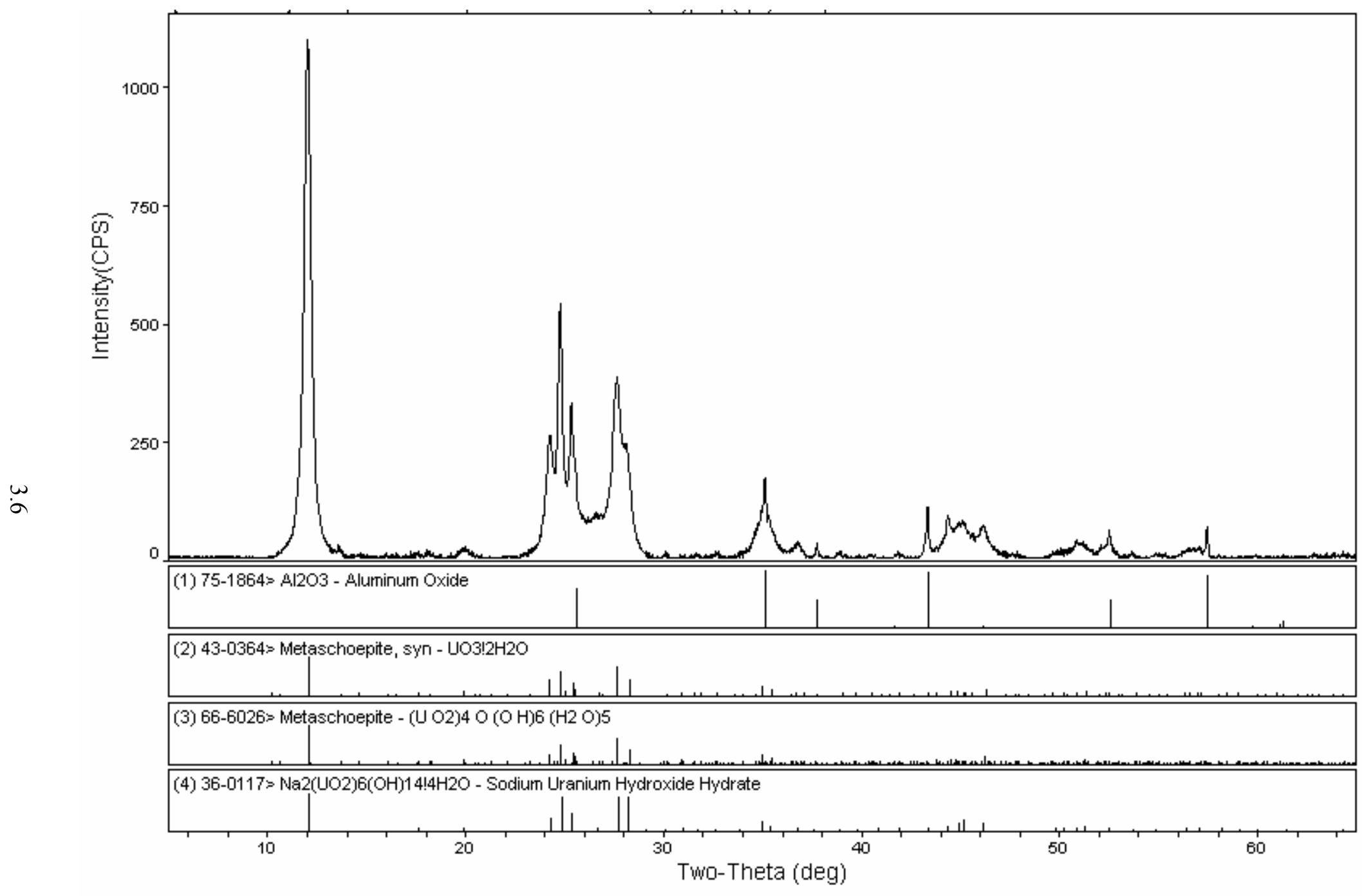

Figure 3.4. XRD Pattern of M1 (2\% neptunium, $\mathrm{pH} 5.5)$ 


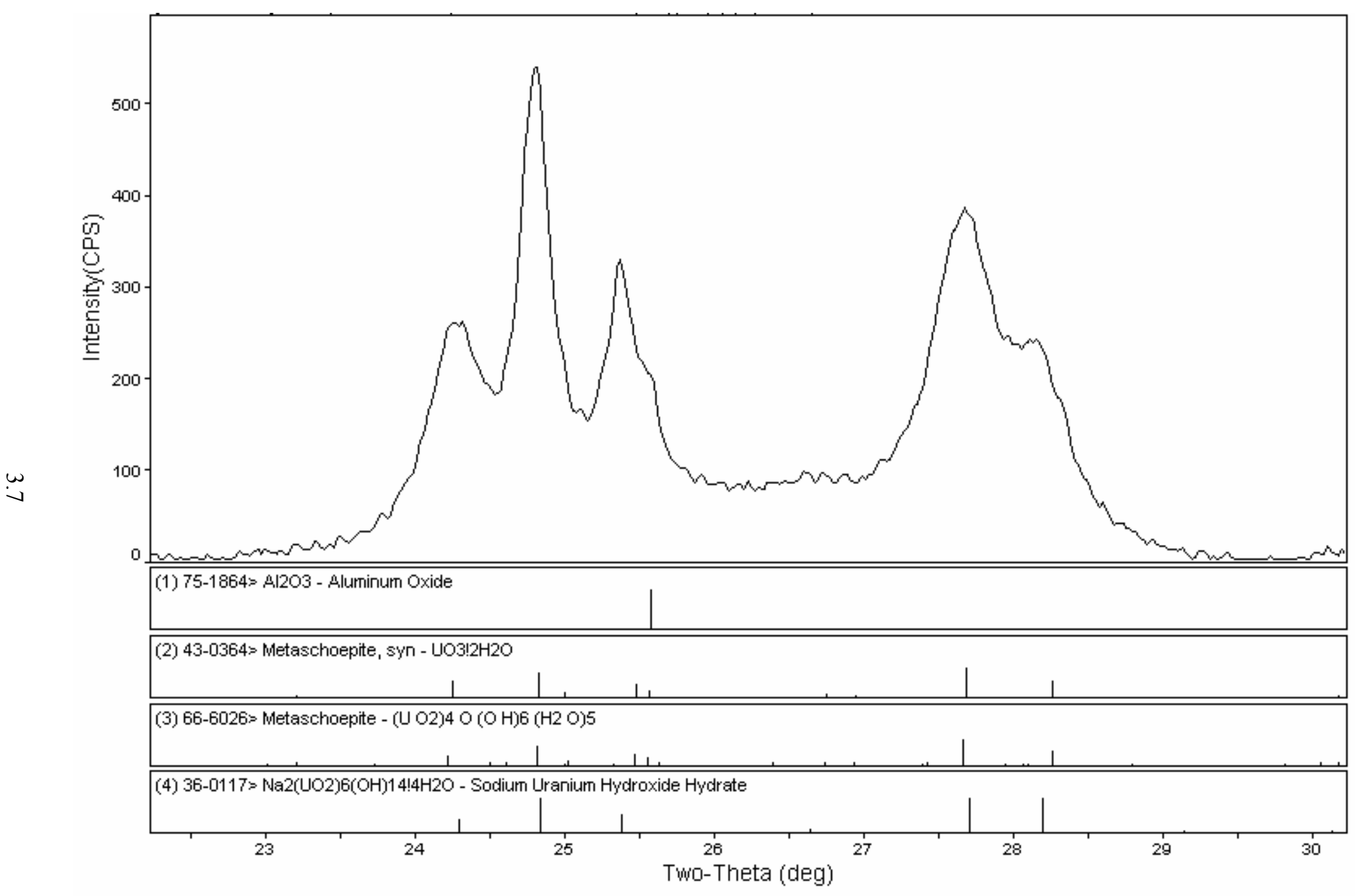

Figure 3.5. XRD Pattern of M1 (2\% neptunium, $\mathrm{pH} 5.5)$ 


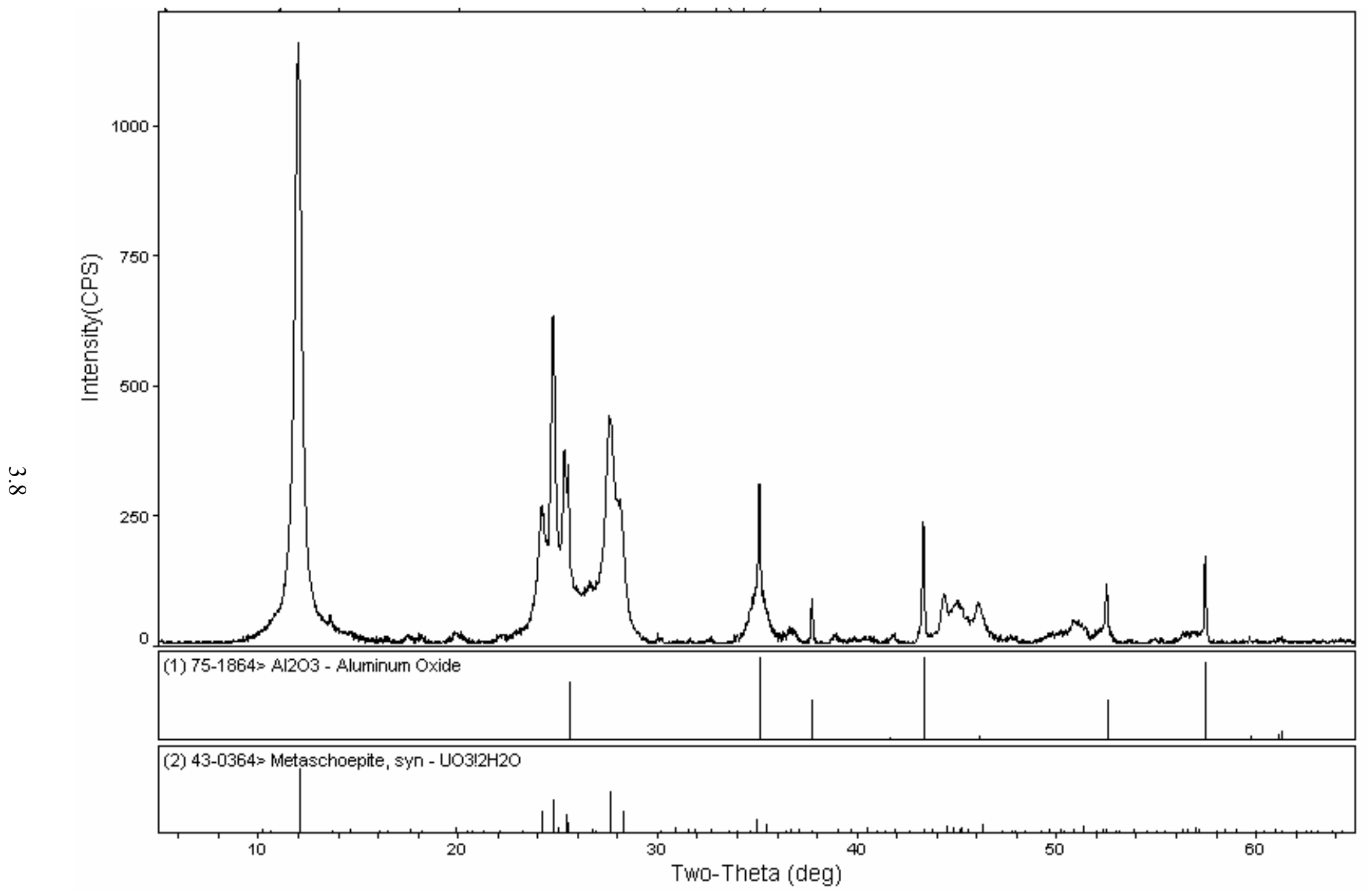

Figure 3.6. XRD Patterns of M4 (no neptunium, $\mathrm{pH}$ 5.5) 


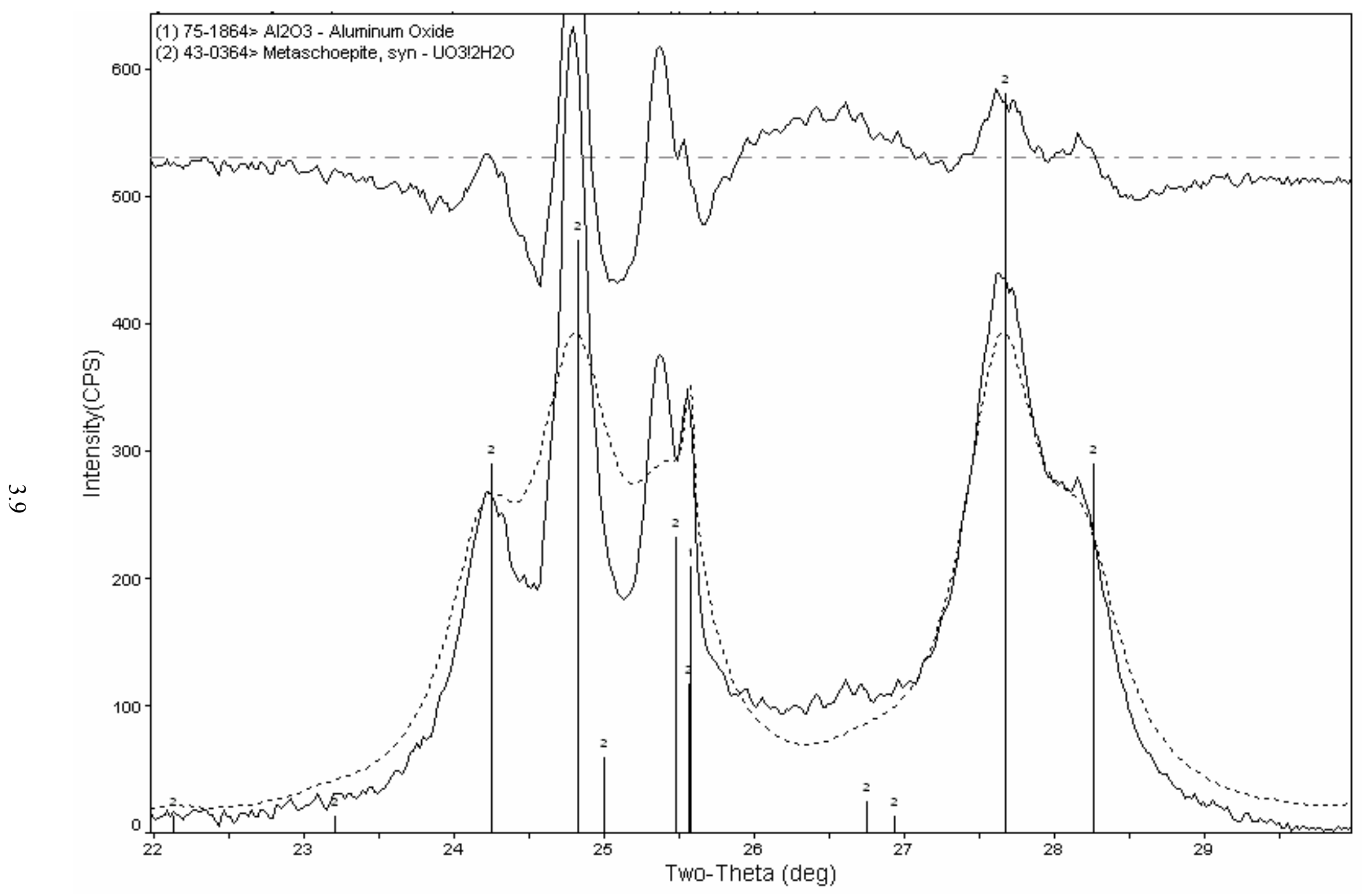

Figure 3.7. XRD Patterns of M4 (no neptunium, pH 5.5) 
Table 3.4. Lattice Parameters from XRD

\begin{tabular}{|c|c|c|c|c|}
\hline & mol \% Np & a & b & c \\
\hline M1 & 2 & 13.78 & 17.03 & 16.39 \\
\hline M2 & 1 & 14.20 & 16.69 & 14.66 \\
\hline M3 & 0.5 & 14.00 & 16.70 & 14.69 \\
\hline M4 & 0 & 13.99 & 16.71 & 14.69 \\
\hline ICDD card 43-364 & 0 & 13.977 & 16.696 & 14.672 \\
\hline
\end{tabular}

\subsubsection{SEM and EDS Data for Samples M1 Through M4 (Meta-schoepite, pH 5.5)}

The SEM images shown in Figure 3.8 through Figure 3.11 differ only in the amount of neptunium initially added to the solution. The morphology of the solids in the images does not differ dramatically. The crystallites are slightly smaller in the samples (M1-M3) that had neptunium in solution, but this difference is small. The EDS spectra of the various areas in the SEM images are all identical (Figure 3.12 and Figure 3.13). This would be expected if most of the neptunium is not associated with the solid, as shown in Section 3.1.1.3.
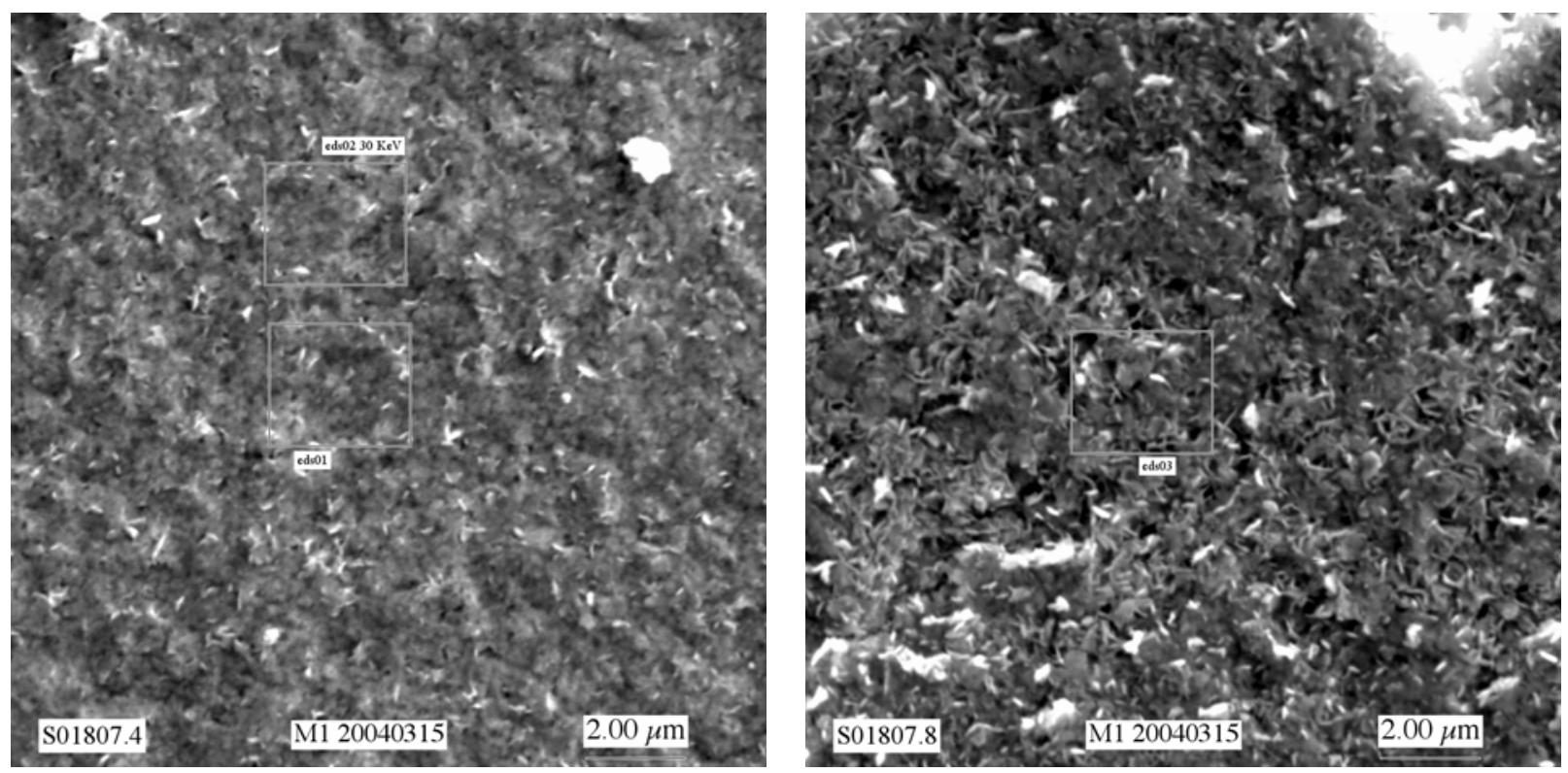

Figure 3.8. SEM Images of Sample M1 (2\% Np, pH 5.5) 

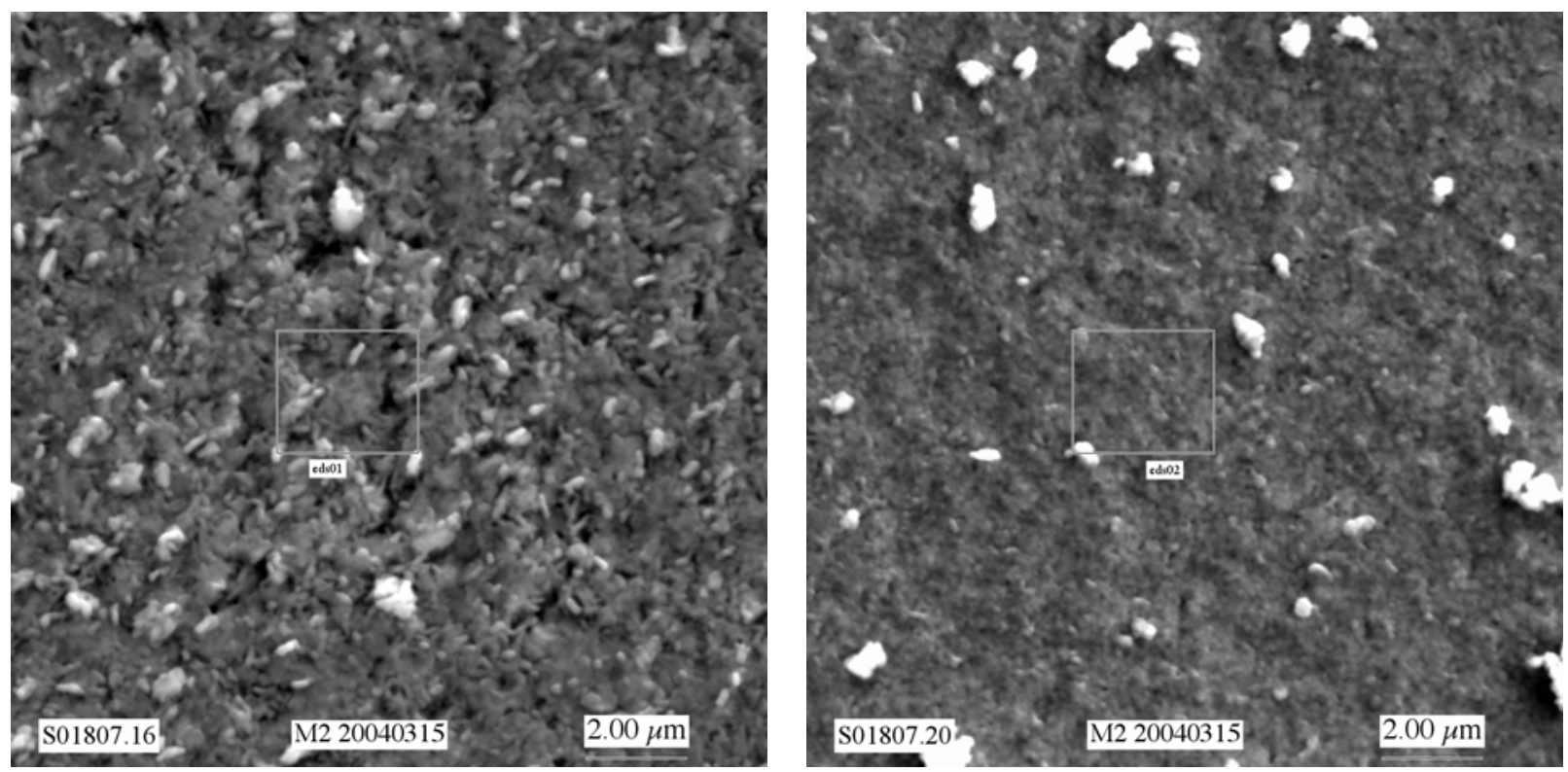

Figure 3.9. SEM Images of Sample M2 (1\% Np, pH 5.5)
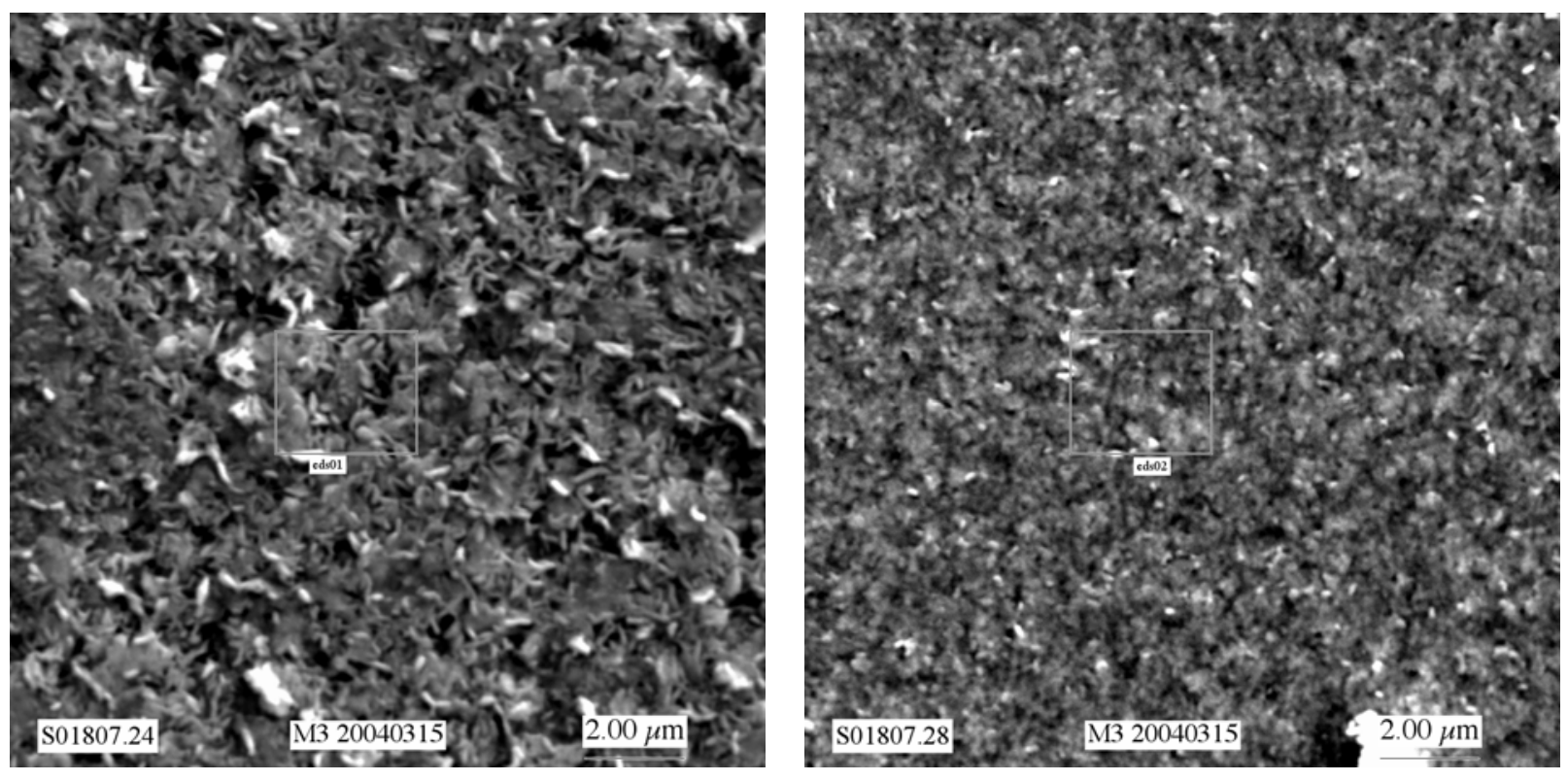

Figure 3.10. SEM Images of Sample M3 $(0.5 \% \mathrm{~Np}, \mathrm{pH} 5.5)$ 

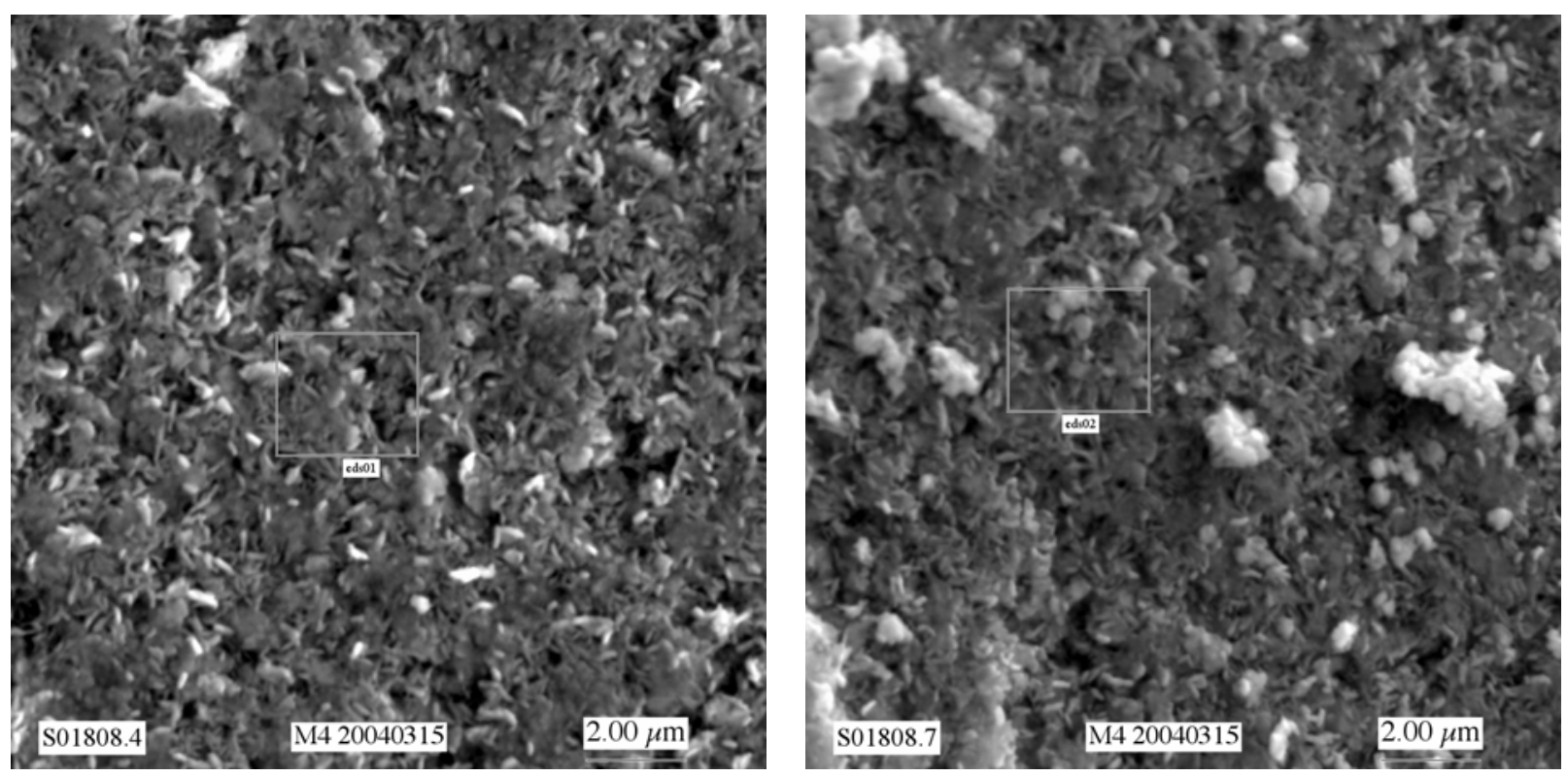

Figure 3.11. SEM Images of Sample M4 ( $0 \% \mathrm{~Np}, \mathrm{pH} 5.5)$ 

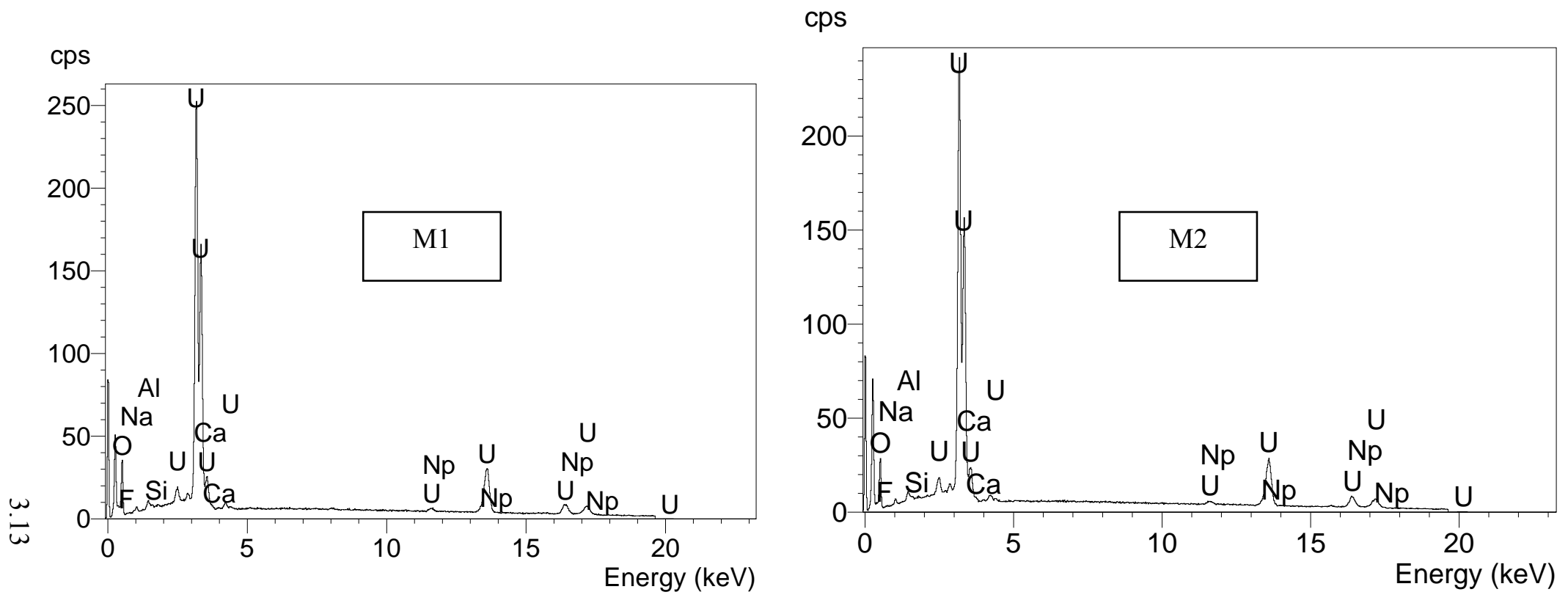

Figure 3.12. EDS Spectra of Samples M1 (2\% Np, pH 5.5) and M2 (1\% Np, pH 5.5) 

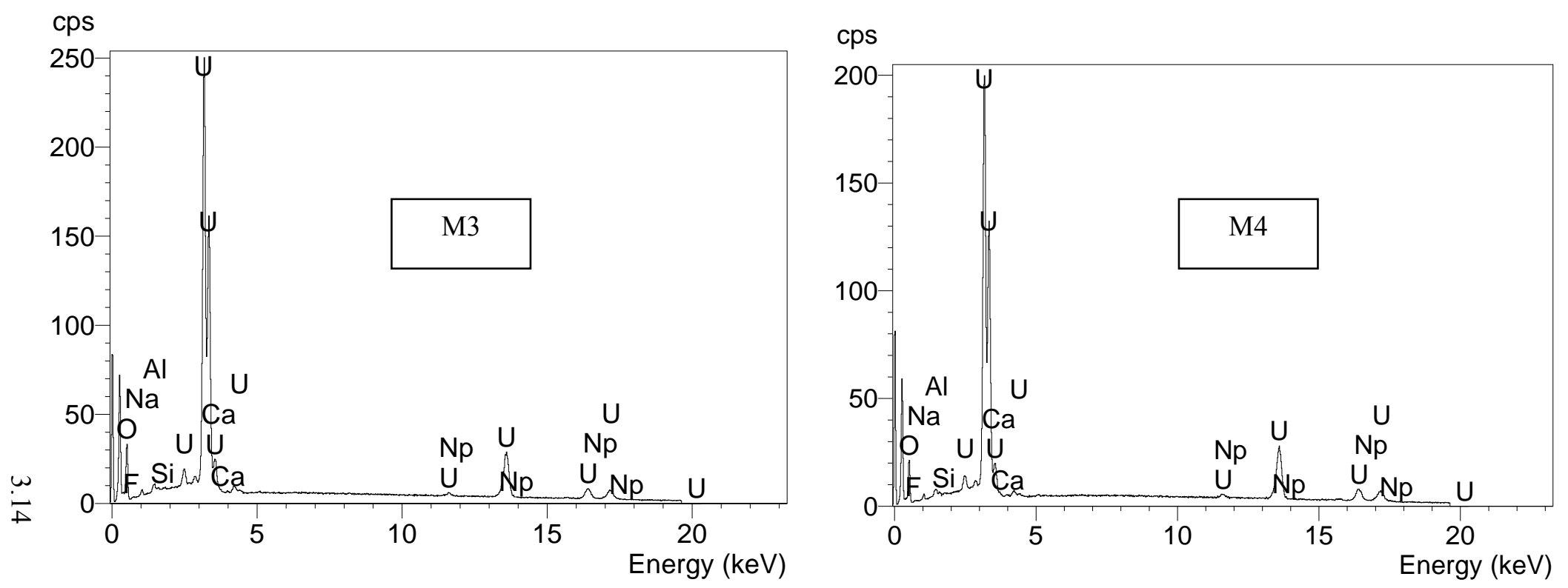

Figure 3.13. EDS Spectra of Samples M3 (0.5\% Np, pH 5.5) and M4 ( $0 \% \mathrm{~Np}, \mathrm{pH} 5.5)$ 


\subsubsection{Radiochemical Data for Samples M1 through M4 (Meta-schoepite at pH 5.5)}

The neptunium GEA data on the second set at $\mathrm{pH} 5.5$ is consistent with the first set as shown in Table 3.5. Meta-schoepite synthesis at pH 5.5 in the presence of neptunium has the majority of the neptunium in solution. The solid was washed three times with water, removing the rest of the neptunium. These data indicate that in the acidic $\mathrm{pH}$ range, the neptunium will not associate with the meta-schoepite in the short term.

Table 3.5. Np Data for Samples M1 through M4

\begin{tabular}{||c|c|c|c||}
\hline \hline Sample ID & Initial Mol \% Np(V) & \% Np(V) in sol'n & Final Np(V) M \\
\hline M1 & 2.0 & 91.20 & $1.82 \mathrm{E}-04$ \\
\hline M2 & 1.0 & 96.52 & $9.65 \mathrm{E}-05$ \\
\hline M3 & 0.5 & 93.87 & $4.69 \mathrm{E}-05$ \\
\hline M4 & 0 & N/A & N/A \\
\hline
\end{tabular}

\subsubsection{Meta-Schoepite pH Series Data (samples M2 and M5 through M7)}

\subsubsection{XRD Data for $\mathrm{pH}$ Series (M2 and M5 through M7)}

The XRD patterns for MS samples synthesized across the $\mathrm{pH}$ range of 4.5 to 8.5 show a slight change (Figure 3.14 through Figure 3.16). In the acidic range, the XRD pattern fits synthetic meta-schoepite very well; however, as the $\mathrm{pH}$ raises, the pattern shifts slightly and fits sodium uranium hydroxide hydrate just as well. These two patterns are quite similar and difficult to distinguish by XRD. As the $\mathrm{pH}$ rises, it is likely that the pattern may shift because of the increased amount of sodium in the system. The sodium was added as sodium hydroxide.

The lattice parameters obtained from fitting the XRD spectra do not give a clear indication of neptunium association with the solid phase (Table 3.6). There is a minor shift in lattice parameters with increasing $\mathrm{pH}$; however, there is also a slight change in phase of the uranium solids as well, and the trend in the lattice parameter may just be an artifact of changing phases rather than neptunium associated with the crystal structure. More information is needed to verify structural association. 


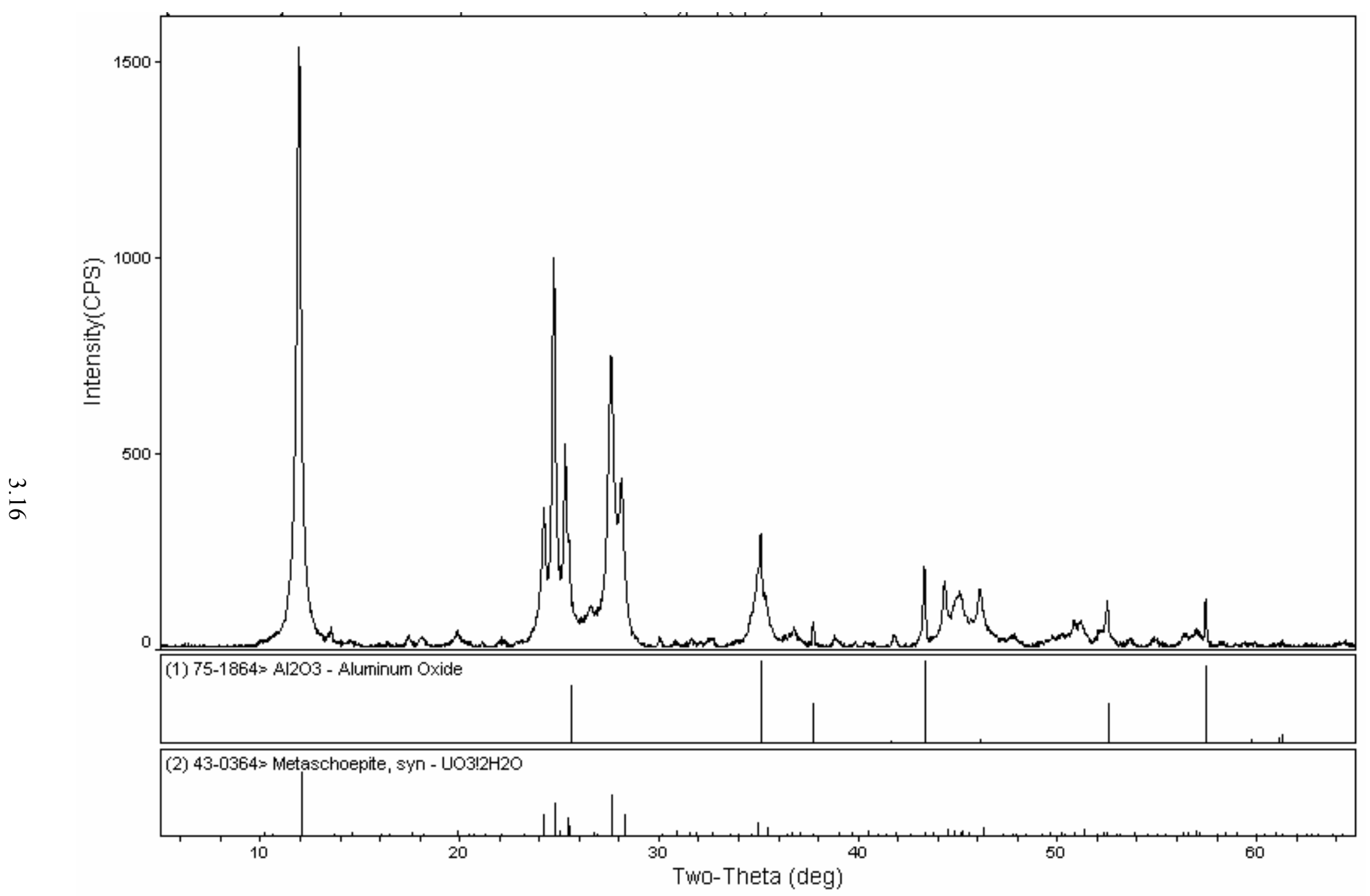

Figure 3.14. XRD Pattern of M5 (1\% Np, pH 4.5) 


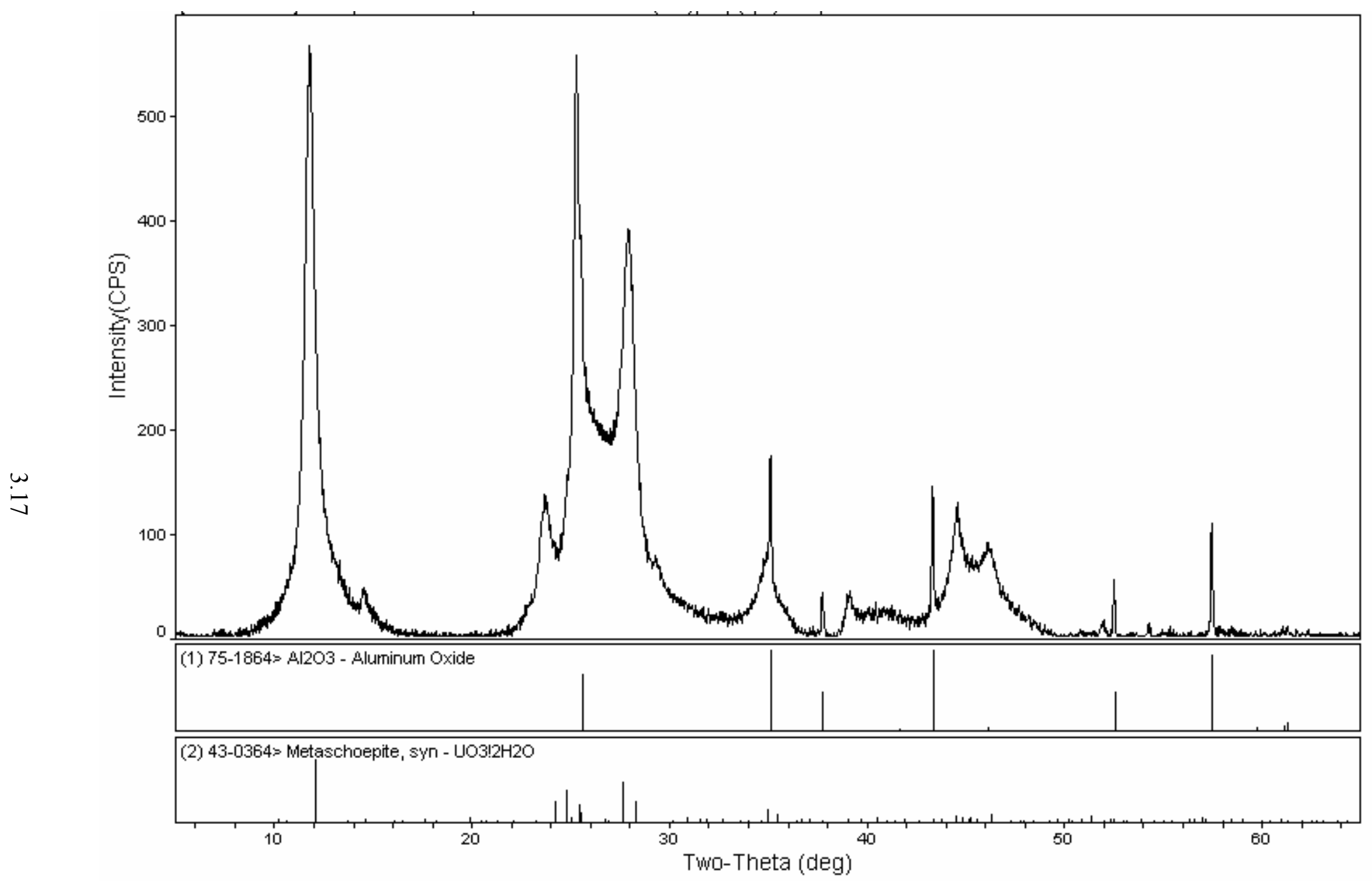

Figure 3.15. XRD Pattern of M6 (1\% Np, pH 6.5) 


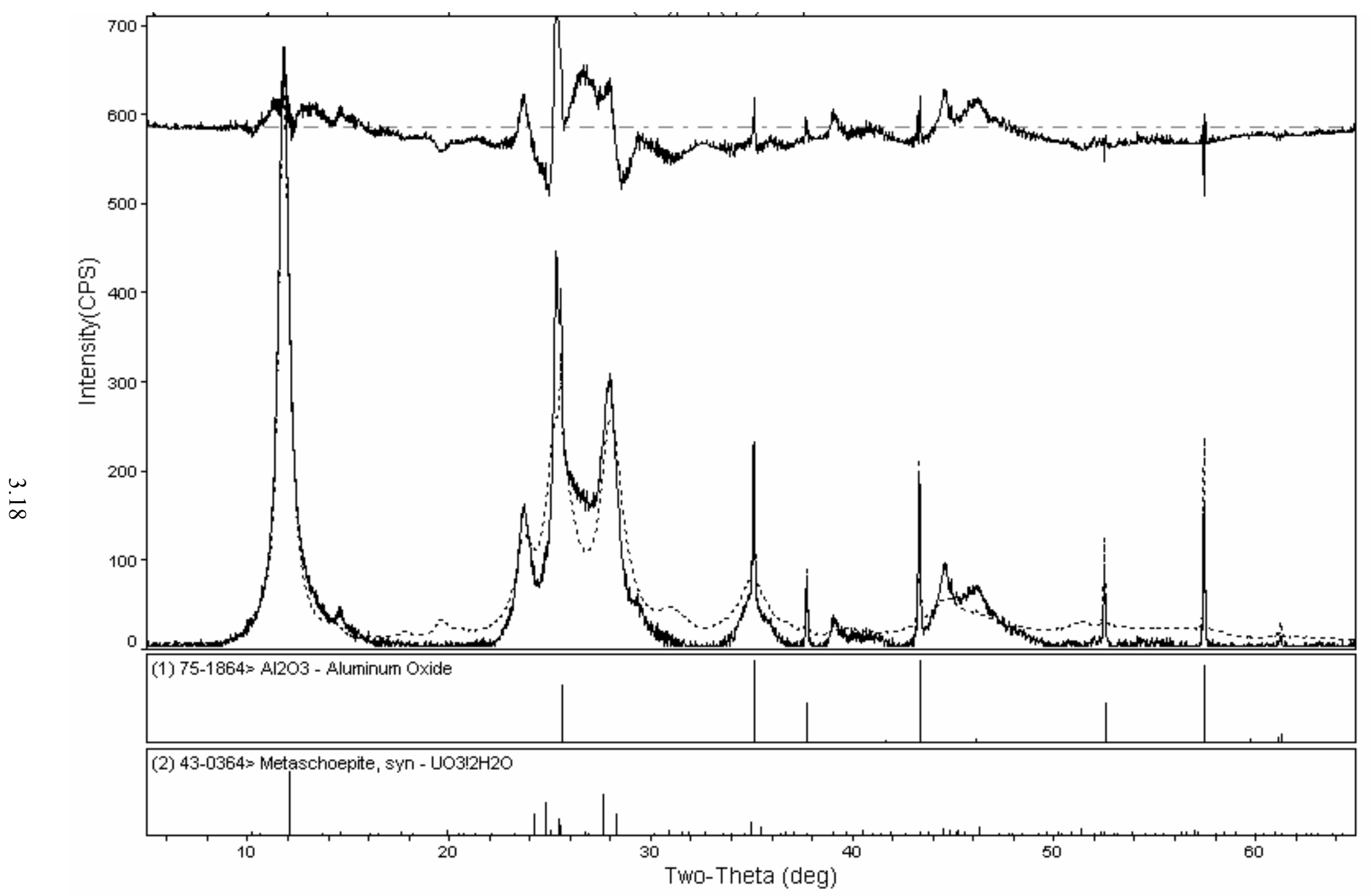

Figure 3.16. XRD Pattern of M7 (1\% Np, pH 8.5) 
Table 3.6. Lattice Parameters for $\mathrm{pH}$ Series

\begin{tabular}{|c|c|c|c|c|c||}
\hline Sample \#'s & mol \% Np & $\mathbf{p H}$ & $\mathbf{a}$ & b & c \\
\hline M2 & 1 & 5.5 & $14.02 \pm 0.01$ & $16.69 \pm 0.01$ & $14.66 \pm 0.01$ \\
\hline M5 & 1 & 4.5 & $14.02 \pm 0.01$ & $16.69 \pm 0.01$ & $14.66 \pm 0.01$ \\
\hline M6 & 1 & 6.5 & $13.73 \pm 0.01$ & $16.57 \pm 0.01$ & $15.04 \pm 0.01$ \\
\hline M7 & 1 & 8.5 & $13.61 \pm 0.02$ & $16.50 \pm 0.02$ & $15.00 \pm 0.02$ \\
\hline ICDD card 43-364 & 0 & & 13.977 & 16.696 & 14.672 \\
\hline
\end{tabular}

\subsubsection{SEM and EDS Data for Samples M5 through M7}

The SEM micrographs in Figure 3.17 through Figure 3.19 of the $\mathrm{pH}$ series indicate a decrease in crystallinity with increasing $\mathrm{pH}$. The samples prepared under acidic conditions show better crystallites than the higher $\mathrm{pH}$ samples. This may be due to a change in phase influenced by the $\mathrm{pH}$ rather than an effect because of $\mathrm{Np}$ association. The EDS spectra are all identical for every sample (Figure 3.20 and Figure 3.21). No neptunium was found in the EDS spectra for all samples which agree with previous results.
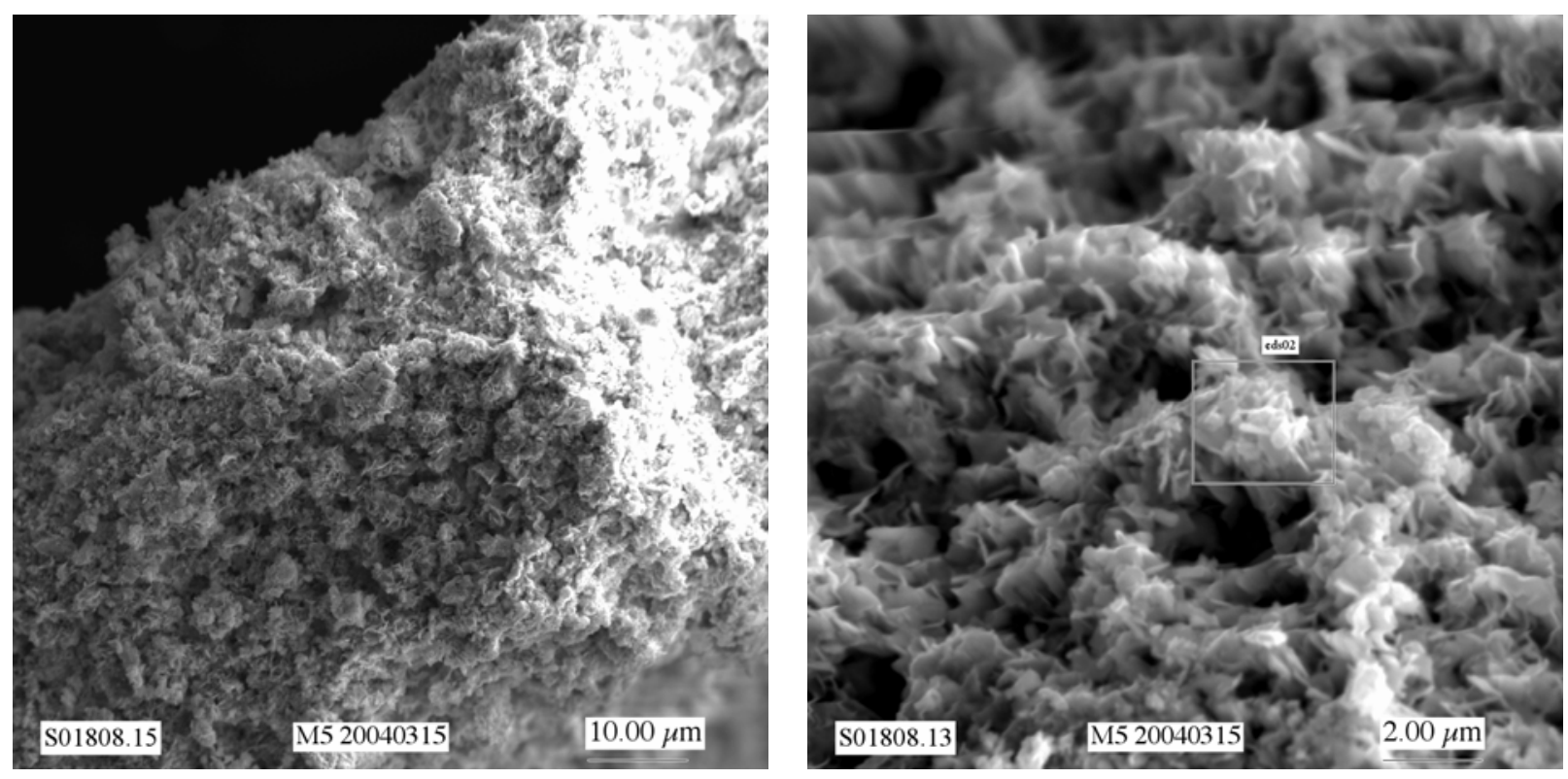

Figure 3.17. SEM Micrographs of Sample M5 (meta-schoepite, $1 \% \mathrm{~Np}, \mathrm{pH} 4.5$ ) 

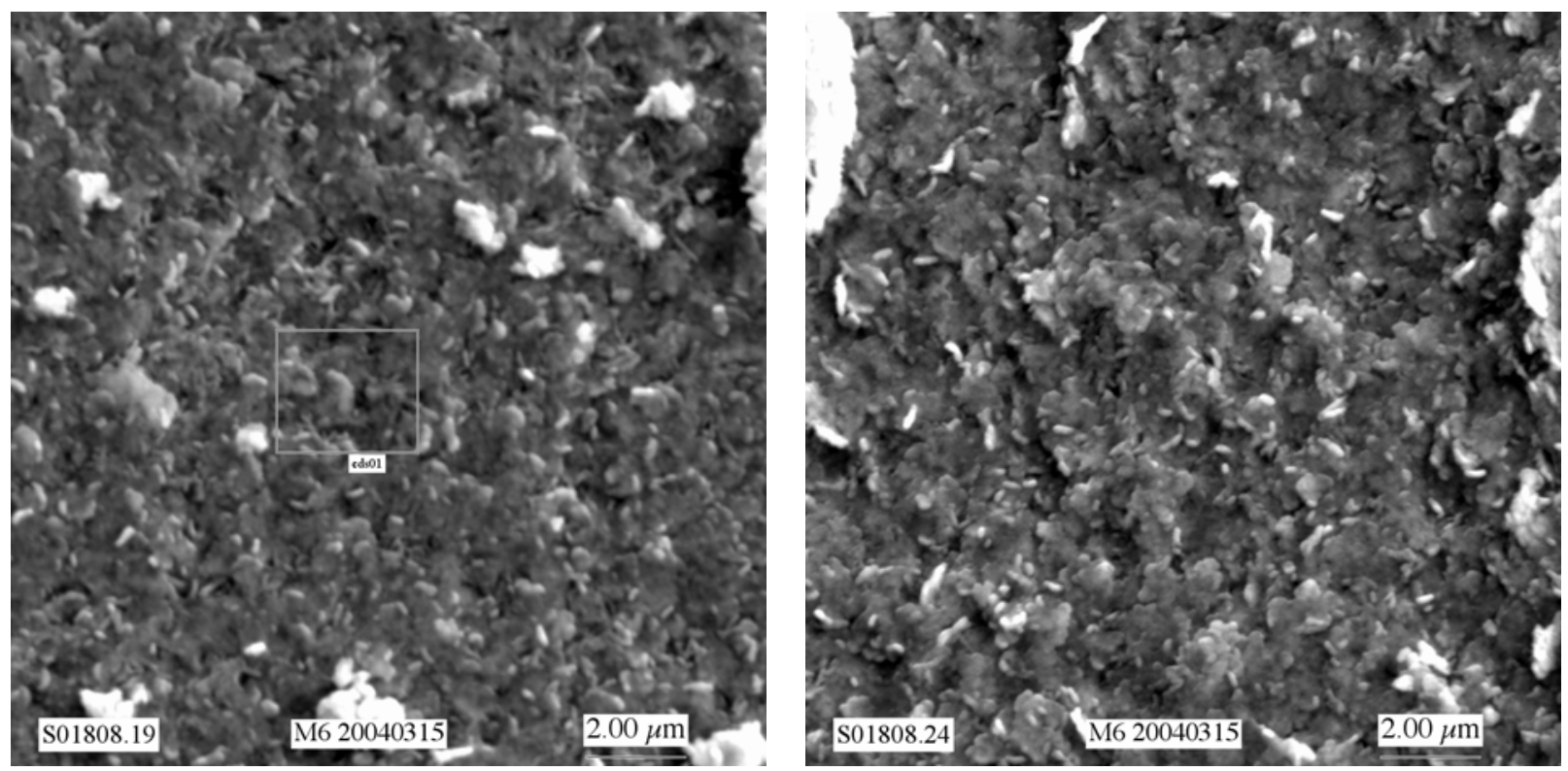

Figure 3.18. SEM Micrographs of Sample M6 (meta-schoepite, $1 \% \mathrm{~Np}, \mathrm{pH}$ 6.5)
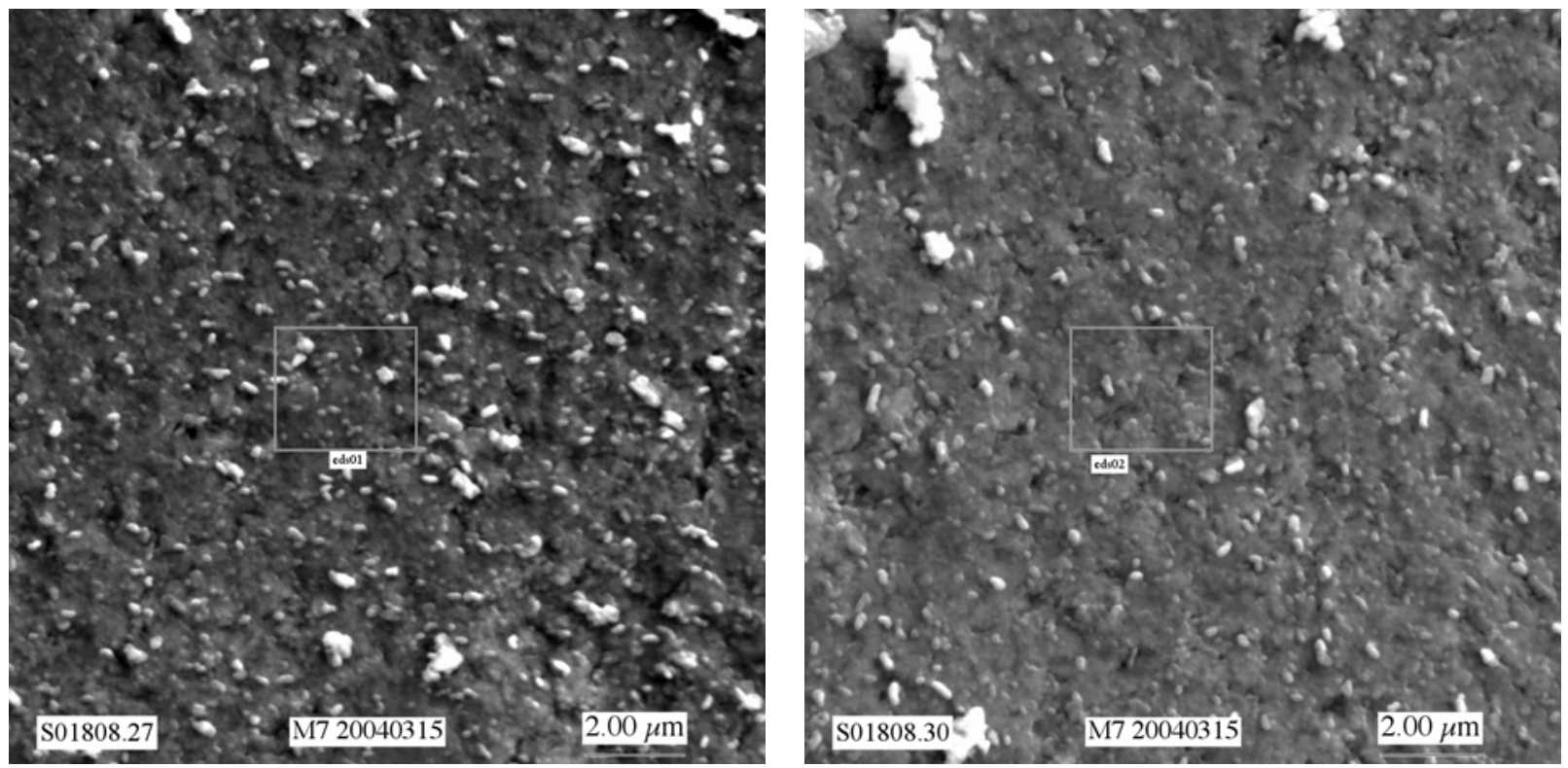

Figure 3.19. SEM Micrographs of Sample M7 (meta-schoepite, $1 \% \mathrm{~Np}, \mathrm{pH}$ 8.5) 

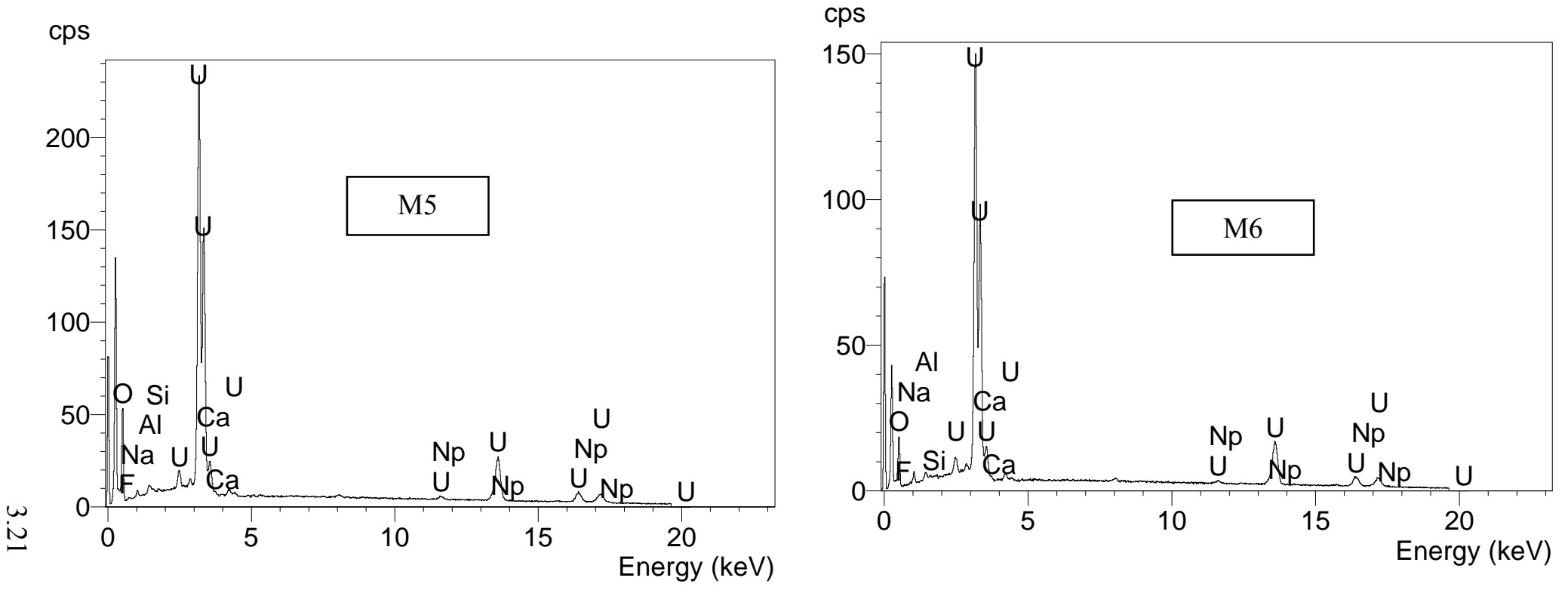

Figure 3.20. EDS Spectra of Samples M5 (pH 4.5) and M6 (pH 6.5) 


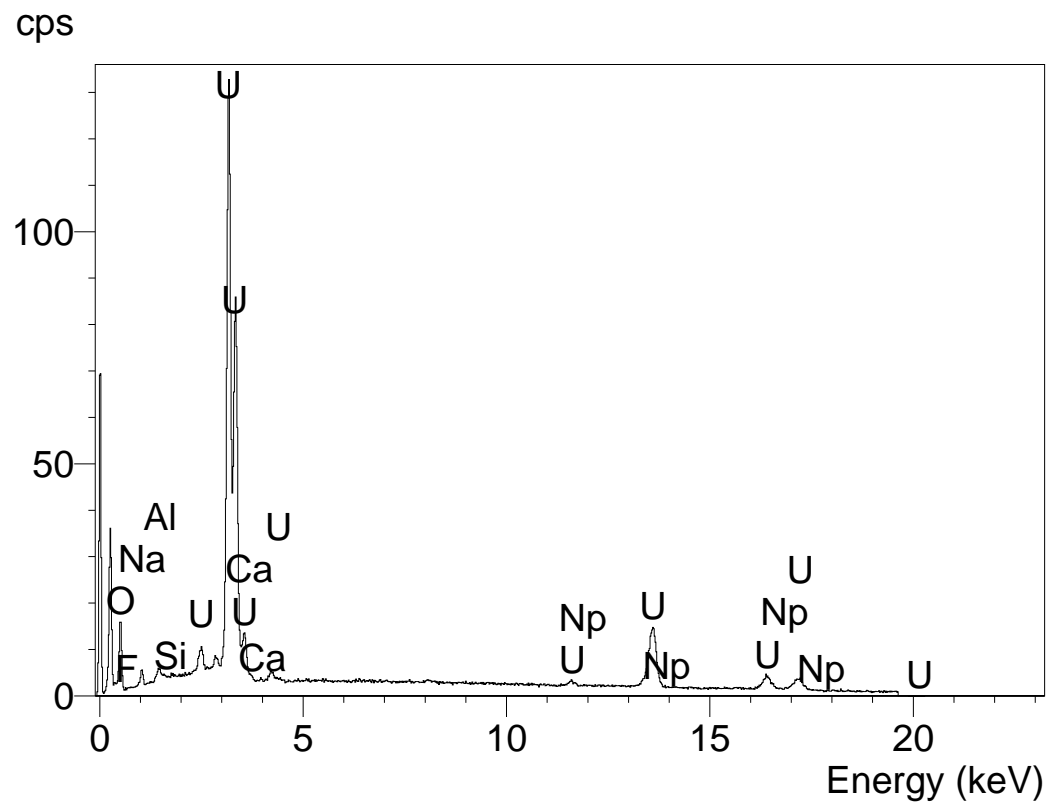

Figure 3.21. EDS Spectra of Sample M7 (pH 8.5)

\subsubsection{Radiochemical Data for Samples 4-18-03B, M2 and M5 through M7}

The radiochemical data for the $\mathrm{pH}$ series indicate an important trend for neptunium behavior. As the $\mathrm{pH}$ of the synthesis is raised, the amount of neptunium in solution declines such that it is undetectable at $\mathrm{pH} 10.4$ as expected for the hydrolysis of neptunium(V). At $\mathrm{pH} 8.5$, about $6 \%$ of the neptunium is associated with the solid (see Figure 3.22 and Figure 3.23), whereas almost $0 \%$ and $100 \%$ is associated with the solid at $\mathrm{pH}$ of 4.5 and 10.4, respectively. Whereas the hydrolysis is expected for neptunium(V), the measured concentration of neptunium in solutions is an order of magnitude lower $\left(\approx 10^{-7} \mathrm{M}\right)$ than that expected for a pure neptunium hydrolysis phase. This trend would indicate that $\mathrm{pH}$ may play an important role in neptunium association with the meta-schoepite solids. The exact chemical form of the neptunium in the solid cannot be determined by these data. 


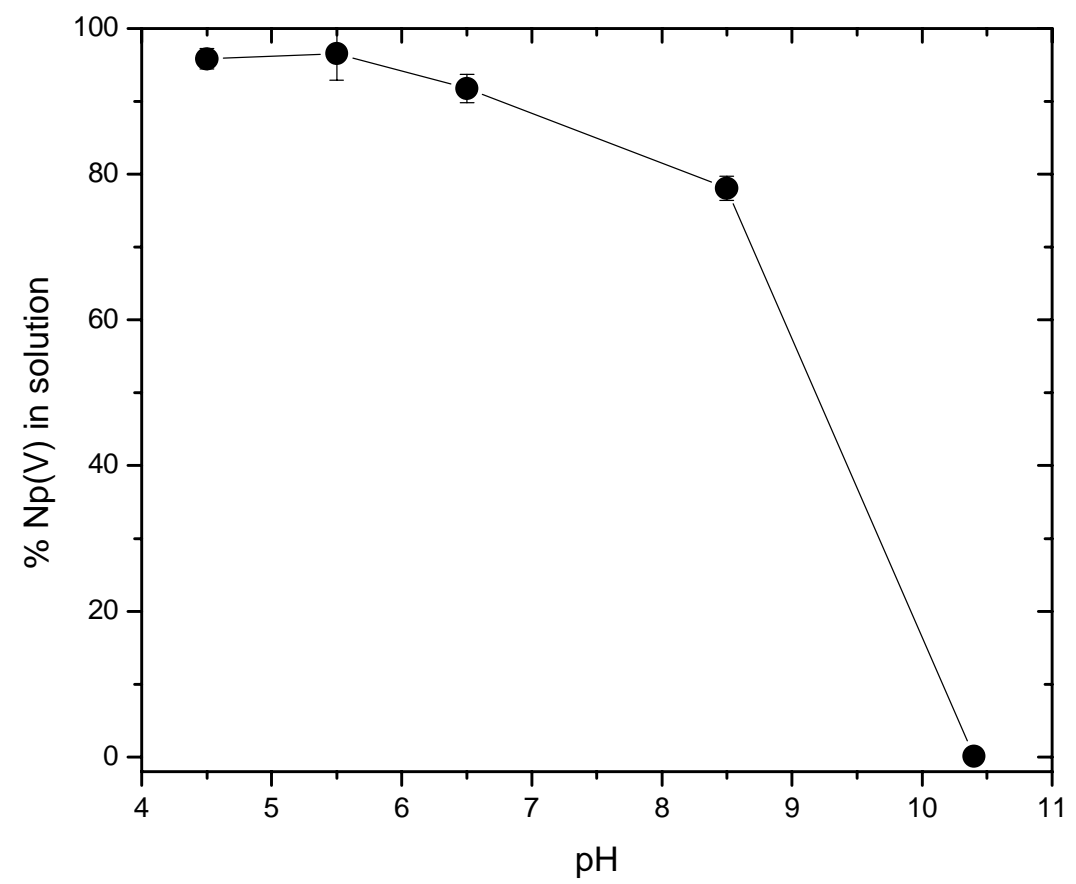

Figure 3.22. Neptunium Solution Concentration in Meta-Schoepite pH Series

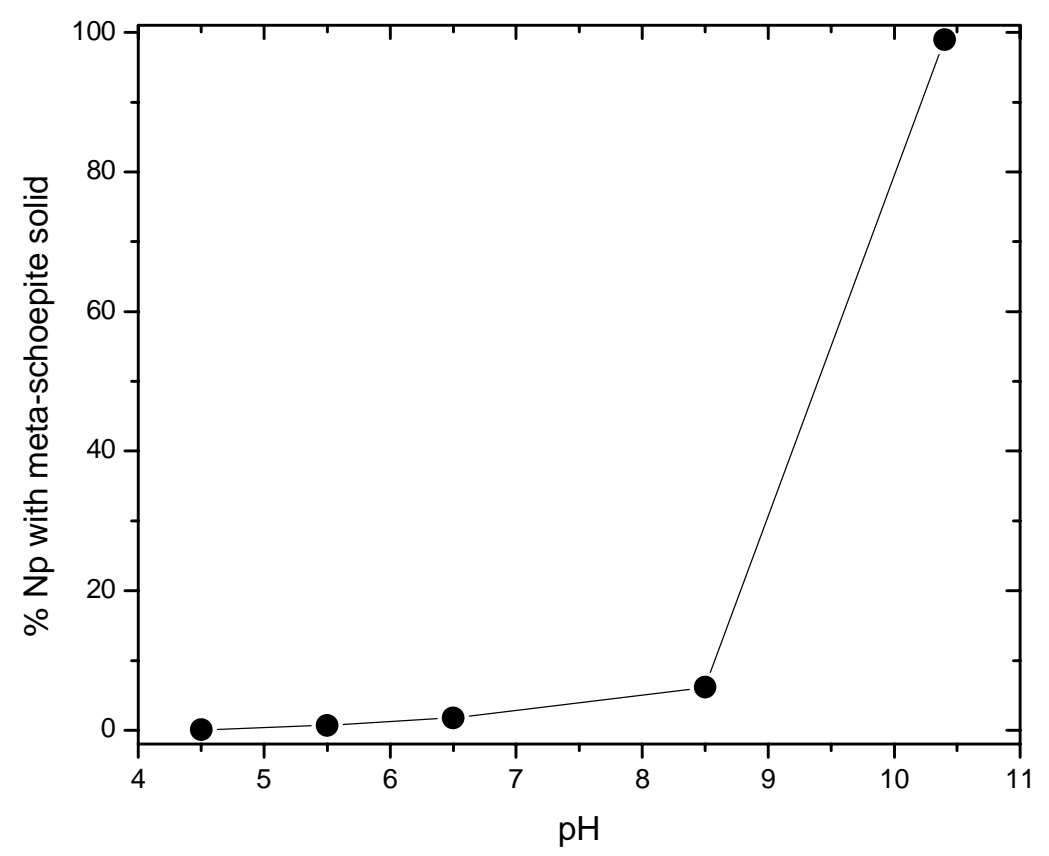

Figure 3.23. Neptunium Solid Concentration in Meta-Schoepite pH Series 


\subsubsection{Summary of Meta-Schoepite Results}

All of the data on Sample 4-18-03B ( $\mathrm{pH} 10.4)$ would seem to indicate that the neptunium is associated with the uranium. The $\mathrm{pH}$ trend from the second set of meta-schoepite data indicates that higher $\mathrm{pH}(>8.5)$ is necessary for neptunium to be associated with the solid. The reason for this higher $\mathrm{pH}$ sample to have the neptunium associated with the solid could be the result of one of several factors:

1. The higher $\mathrm{pH}$ of the sample resulting in a slightly different phase

2. Neptunium hydrolysis product forms limiting solubility

3. The higher ionic strength of the sample, resulting in charge-balancing to allow Np incorporation/coprecipitation.

For neptunium to be substituted for uranium in the sheet structure of meta-schoepite, a chargebalancing mechanism must be present to balance the overall charge. The inner layer of meta-schoepite is typically occupied by water. In a higher ionic strength environment, it may be possible to insert an ion into this layer to balance the charge. Potentially at $\mathrm{pH} 10.4$, there may have been enough sodium ions present to enter this inner layer and balance the charge, allowing neptunium to enter the sheet in place of uranium.

Beyond co-precipitation of the hydrolysis products of uranium and neptunium, the mechanism of neptunium incorporation as a function of $\mathrm{pH}$ is inconclusive. Further testing of the ionic strength and $\mathrm{pH}$ dependence of neptunium incorporation into meta-schoepite is needed.

\subsection{Meta-Studtite Results}

Two samples of meta-studtite were synthesized from meta-schoepite solids, one with $2 \%$ neptunium and one without (Table 3.7). The meta-schoepite solids were synthesized at low $\mathrm{pH}$; thus, the neptunium would be expected to remain in solution and not be associated with the solid phase, as discussed in Section 3.1. The synthesis of meta-studtite was simply the addition of peroxide to the solution.

Table 3.7. Radiochemical Data from Meta-Studtite Tests at Various Neptunium Concentrations

\begin{tabular}{|l|c|c||}
\hline \multicolumn{1}{|c|}{ Studtite } & 4-30-03D & 4-30-03E \\
\hline pH & 5.5 & 5.5 \\
\hline InitialMol \% Np & 2 & 0 \\
\hline [U] sol'n & Not Measured & Not Measured \\
\hline [Np] solid & $6500 \mathrm{ppm}$ & NA \\
\hline [Np] sol'n & $<3.7 \mathrm{E}-8 \mathrm{M}$ & NA \\
\hline
\end{tabular}


The meta-schoepite sample (4-30-03D) that should have had no neptunium associated with it acquired most of the neptunium from solution when peroxide was added to convert to meta-studtite as indicated in Table 3.7. The solution concentration of neptunium dropped almost four orders of magnitude when metastudtite was present as the uranium solid phase as compared to meta-schoepite. This may be because the neptunium was oxidized by the peroxide and is, therefore, more readily associated or it may be that the structure of meta-studtite more readily allows association than that of meta-schoepite.

Figure 3.24 and Figure 3.25 indicate that there is little change in the XRD reflections despite the one sample having $2 \mathrm{~mol}$ percent neptunium associated with the solid.

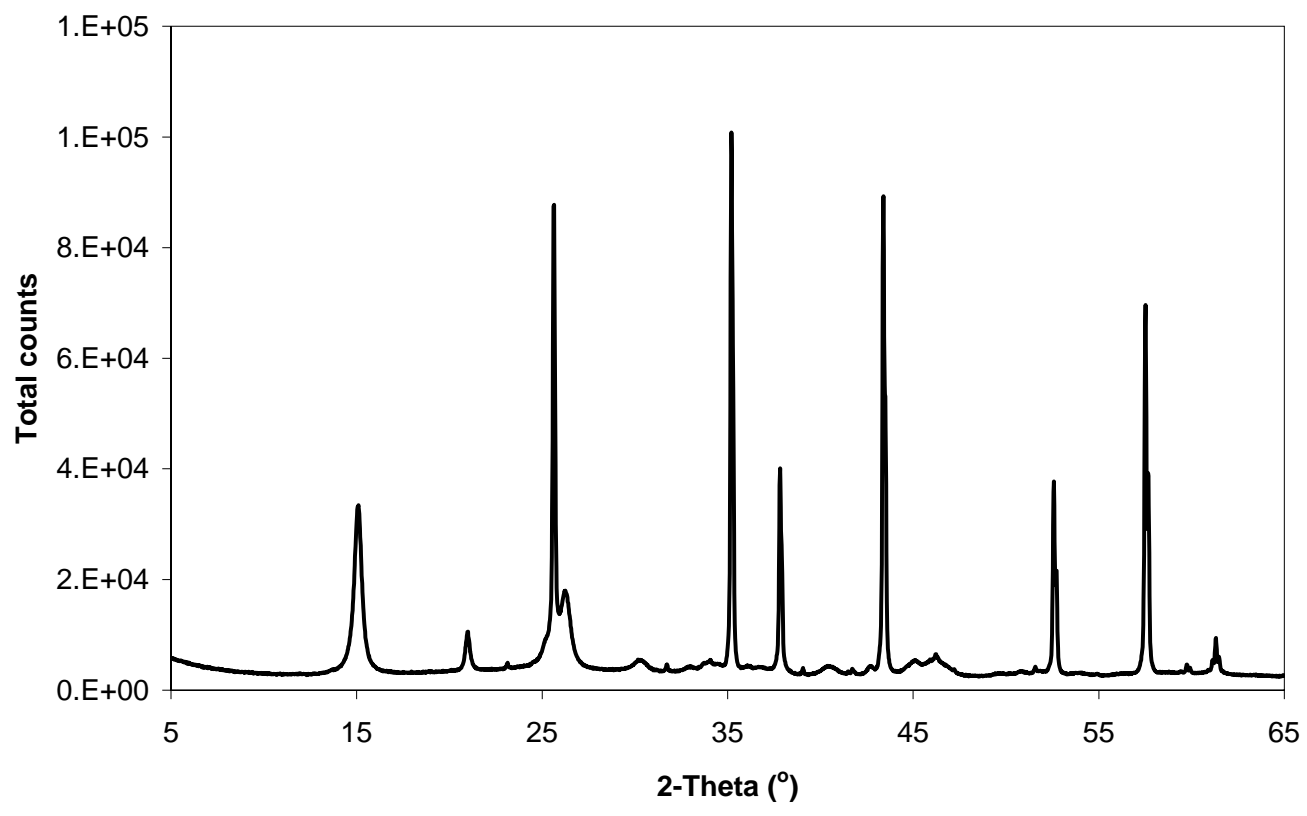

Figure 3.24. XRD Pattern of Studtite Sample (4-30-03D) 


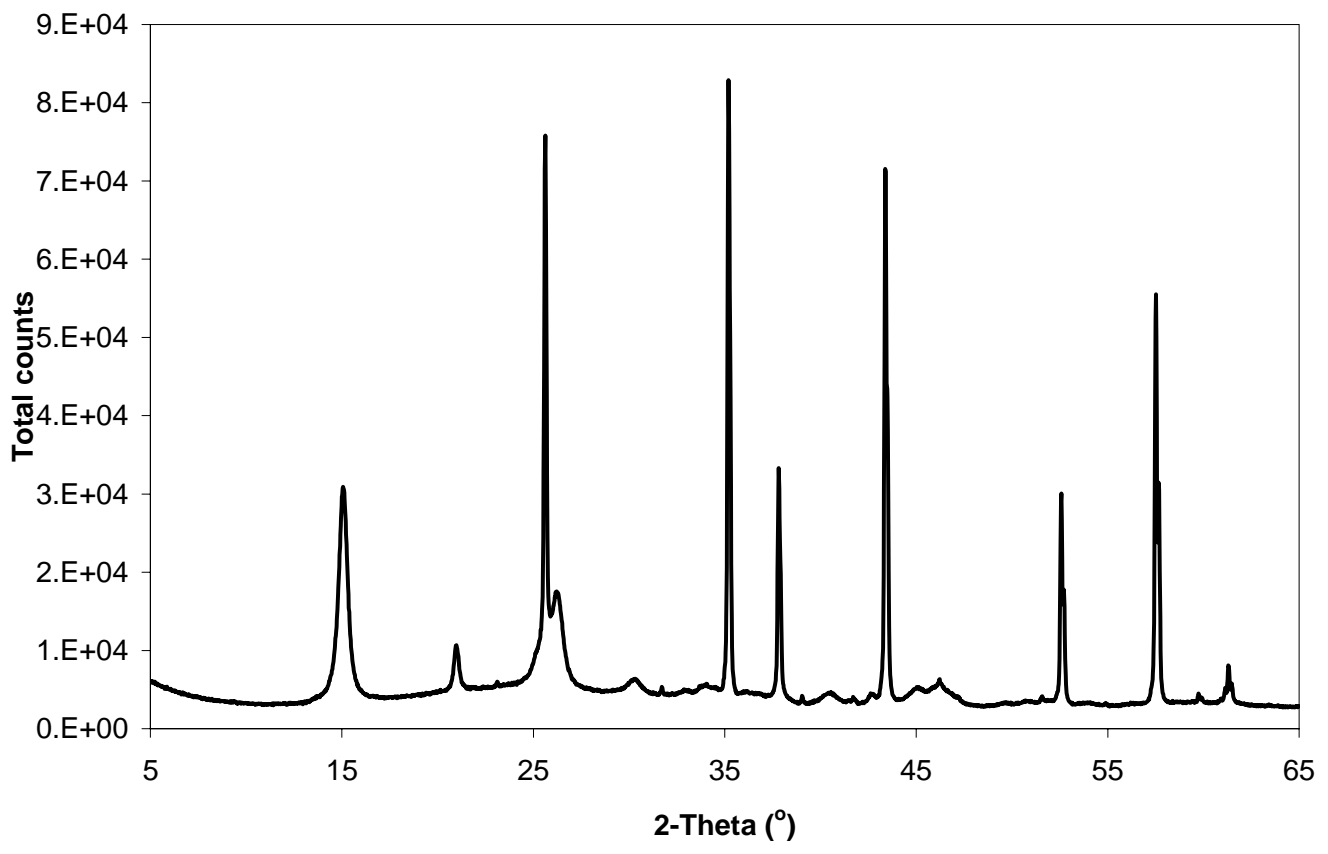

Figure 3.25. XRD Pattern of Studtite Sample (4-30-03E)

Figure 3.26 indicates a slight difference in morphology between the studtite samples. The samples with neptunium associated with them ( $6 \mathrm{a}$ and $6 \mathrm{~b}$ of Figure 3.26$)$ have a much smaller crystal size. The individual crystallites are only slightly different between the two samples. The representative EDS spectra (one of four) in Figure 3.27 and Figure 3.28 indicate no difference between the two samples. No neptunium-rich areas were detected by EDS.

Neptunium sequestration with studtite likely occurs due to the oxidation of neptunium(V) to neptunium(VI), which is identical to uranium(VI) in shape and charge. No charge-balancing mechanisms are necessary for neptunium associate with studtite. These data, in combination with previous published results (McNamara et al. 2003), indicate that the neptunium is readily associated with meta-studtite. Although not conclusive this is evidence that the neptunium may be incorporated into the structure of meta-studtite.

Recent results by Douglas et. al. (Douglas 2004) on the dissolution of neptunium doped meta-studtite indicated that under the dissolution conditions $\left(\mathrm{pH} 6,0.01 \mathrm{M} \mathrm{NaNO}_{3}\right)$ used, neptunium and uranium do not release congruently, with neptunium being released rapidly. Douglas suggests several possibilities for these results, including the lack of a strong oxidizing environment allowing the reduction of $\mathrm{Np}(\mathrm{VI})$ to $\mathrm{Np}(\mathrm{V})$, the lack of incorporation of neptunium into the studtite structure and the change in dissolution chemistry. Further studies are necessary to successfully evaluate the mechanism in the studtite system. 

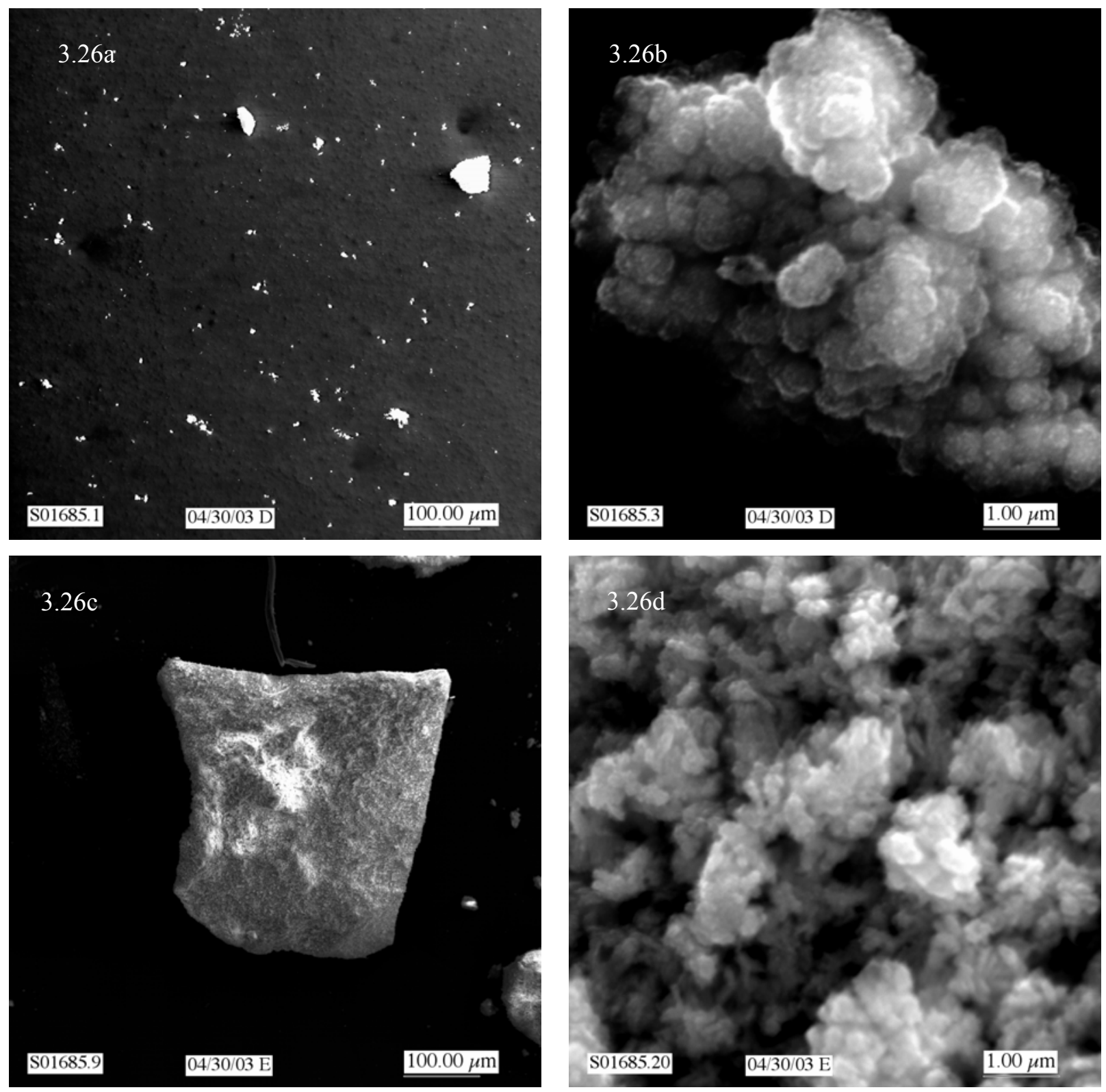

Figure 3.26. SEM Images of the Two Studtite Samples.

(Parts 3.26a and 3.26b contain $\sim 2 \% \mathrm{~Np}$; 3.26c and 3.26d have no Np) 


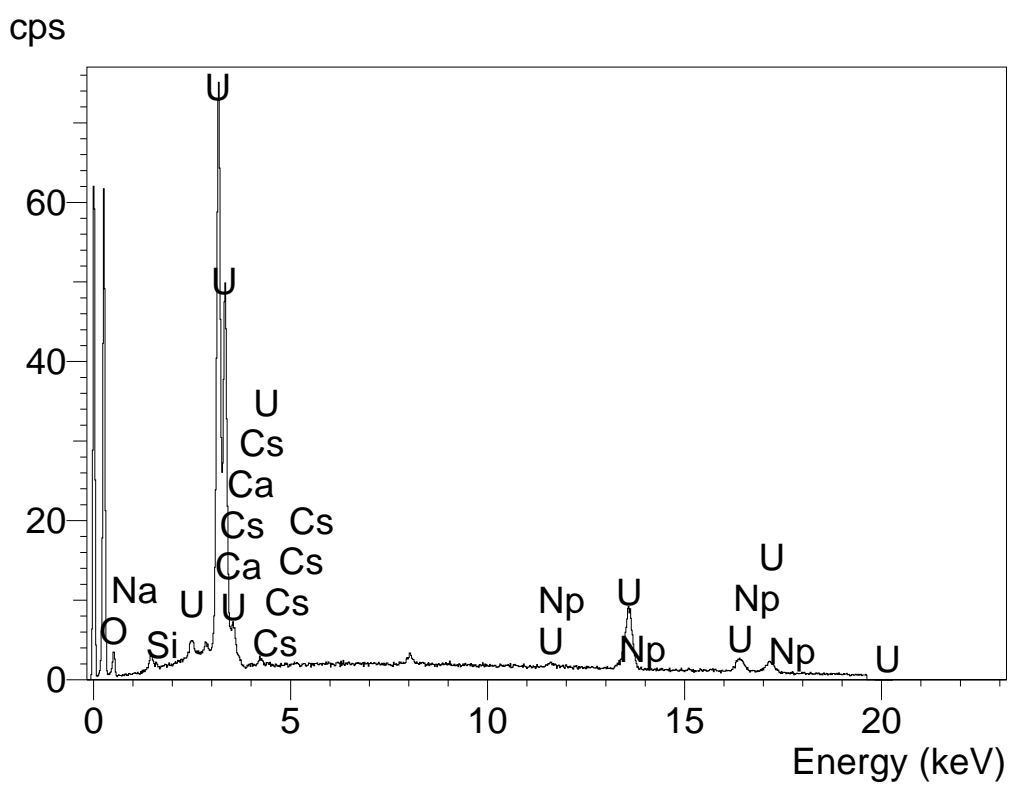

Figure 3.27. EDS Spectrum of Neptunium Associated Studtite Sample (4-30-03D)

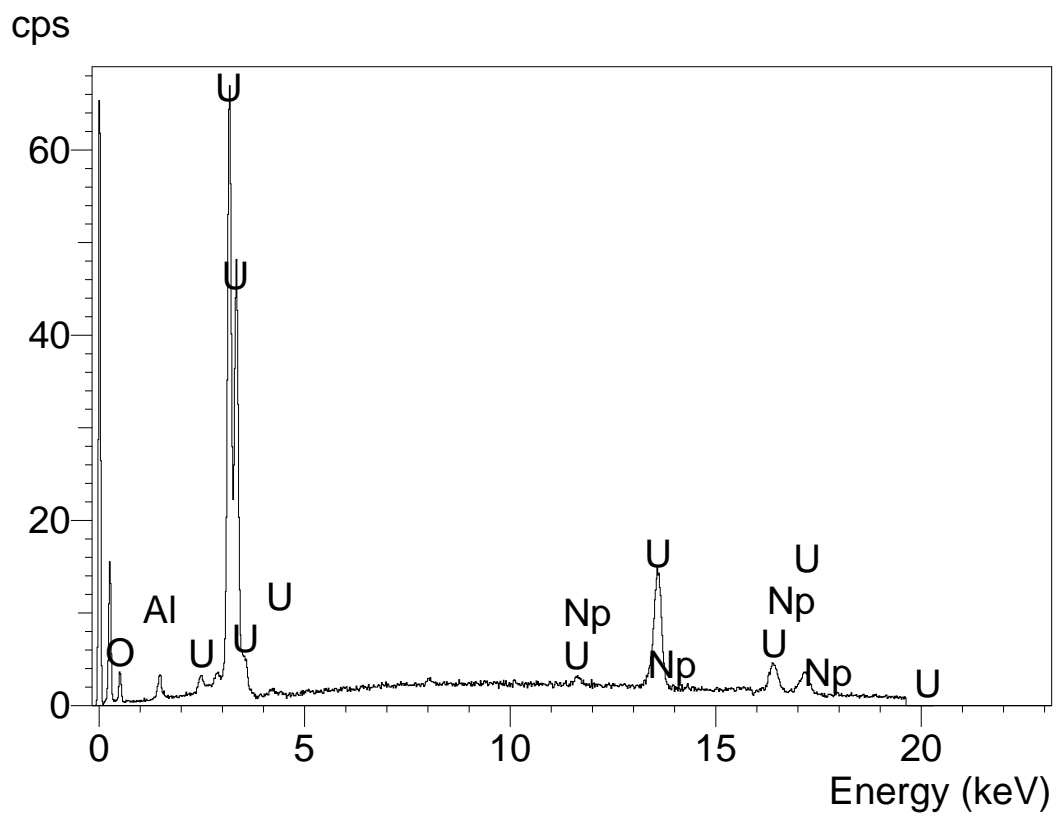

Figure 3.28. EDS Spectrum of Studtite Sample (4-30-03E) 


\subsection{Uranophane Results}

Two separate sets of uranophane samples were synthesized. The first set consisted of six samples of uranophane synthesized with and without neptunium. The second set was a duplication of the E, F, G, and $\mathrm{H}$ samples of the first set in an attempt to synthesize a pure uranophane solid phase. This synthesis requires the use of Parr pressure vessels at elevated temperatures. Producing a pure uranophane phase is difficult and is often accompanied by production of other uranium mineral phases.

\subsubsection{Characterization of the First Uranophane Synthesis Set}

Initial XRD results for the 3-20-03 samples (Figure 3.29) indicate that there is at least one other phase present in addition to uranophane. This phase was identified as sodium boltwoodite, which has a similar sheet structure as uranophane, with the inner layer cations differing. Samples prepared later (4-30-03) had a higher percentage of uranophane as indicated by Figure 3.30. The "extra" peaks in the spectra are from the $\mathrm{Al}_{2} \mathrm{O}_{3}$ added as an internal standard.

Radiochemical data presented in Table 3.8 indicate that neptunium is associated with these solid phases. All samples that were synthesized in the presence of neptunium had the majority of neptunium associated with the solid phase with only a minor fraction remaining in solution. The samples that had a mixture of uranophane and sodium boltwoodite indicate that the amount of neptunium that is associated with the solid is proportional to the amount of starting-solution neptunium.

Table 3.8. Radiochemical Data from Uranophane Tests at Various Neptunium Concentrations

\begin{tabular}{||l|c|c|c|c|c|c||}
\hline Uranophane & 4-30-03A & 4-30-03B & 3-20-03E & 3-20-03F & 3-20-03G & 3-20-03H \\
\hline pH & 10.04 & 10.02 & 9.7 & 10.0 & 9.9 & 9.7 \\
\hline Initial Mol \% Np & 2 & 0 & 2 & 1 & 0.5 & 0 \\
\hline [U] sol'n & Not Measured & Not Measured & $1.15 \mathrm{E}-7 \mathrm{M}$ & $3.92 \mathrm{E}-8 \mathrm{M}$ & $6.95 \mathrm{E}-8 \mathrm{M}$ & $9.79 \mathrm{E}-8 \mathrm{M}$ \\
\hline [Np] solid & $780 \mathrm{ppm}$ & & $6300 \mathrm{ppm}$ & $3000 \mathrm{ppm}$ & $1700 \mathrm{ppm}$ & \\
\hline [Np] sol'n & $1.71 \mathrm{E}-7 \mathrm{M}$ & & & & & \\
\hline \% Np in sol'n & 0.10 & & 0.075 & 0.13 & 0.26 & \\
\hline
\end{tabular}

Each synthesis is slightly different due to uncontrollable factors. Often the surface area of each synthesized solid is quite different, causing the uranium and neptunium in the system to behave differently in the wash steps. Given enough time for the solids to become more crystalline, then the various samples would behave in a more similar manor. It is this reason that samples 4-18-03A and 3-2003E have different amounts of neptunium associated with the solid. 


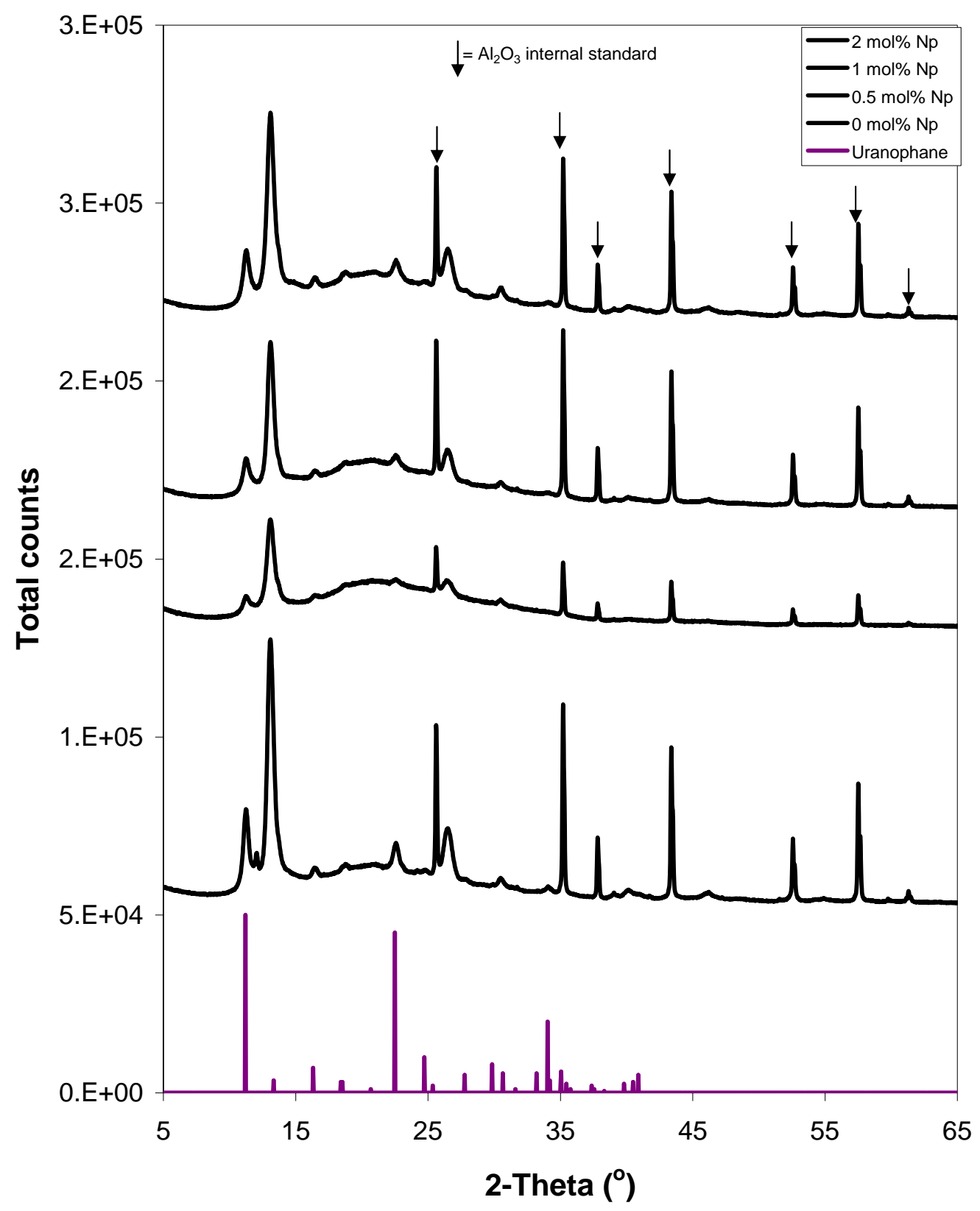

Figure 3.29. XRD Pattern of Samples 3-20-03E through 3-20-03H 


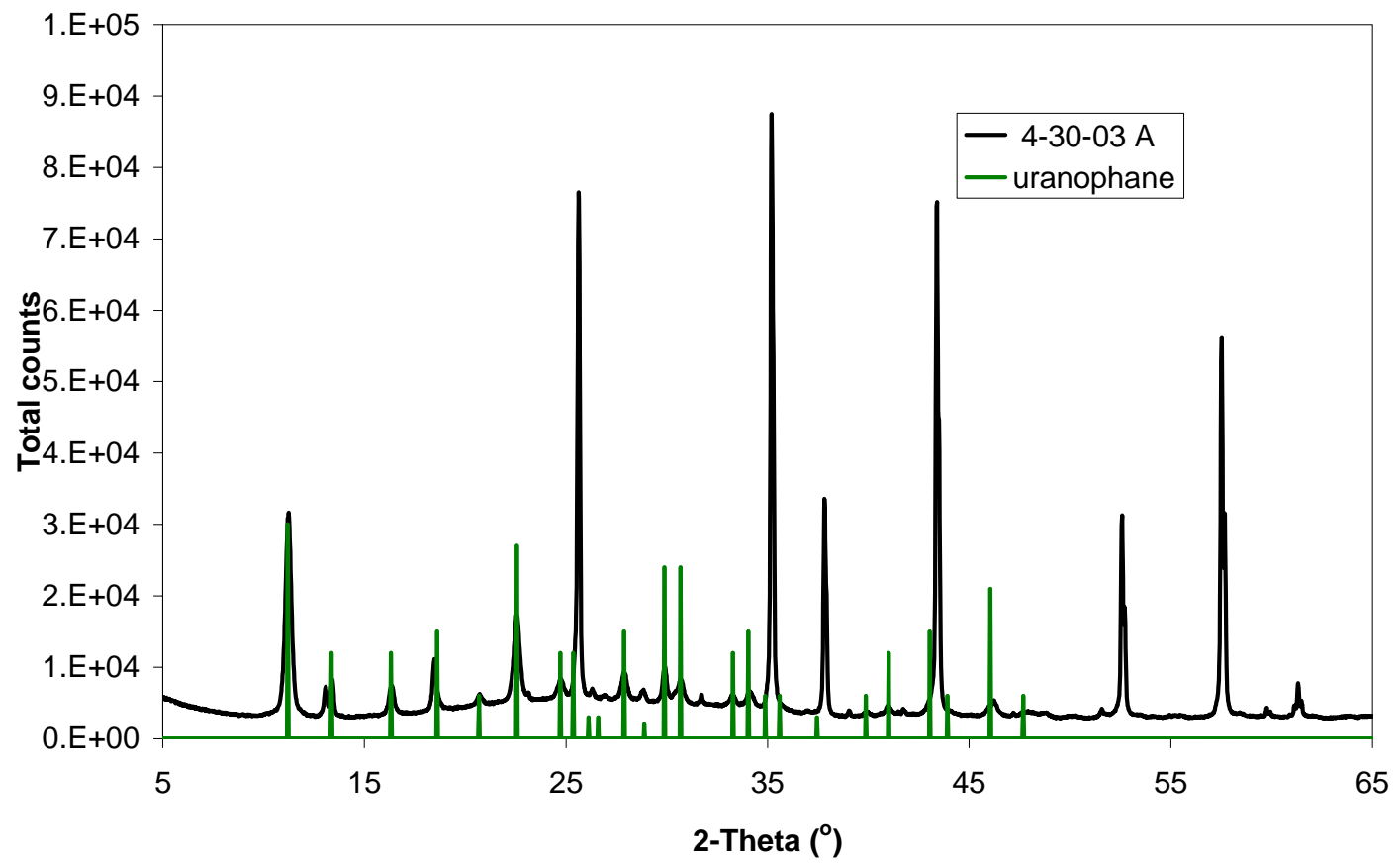

Figure 3.30. XRD Pattern of 4-30-03A. (780 ppm Np in the Sample)

The SEM figures (Figure 3.31 through Figure 3.33) show two important differences between samples that do and do not have neptunium. The samples with neptunium have smaller crystallites. This general trend is similar to the meta-schoepite samples. Uranophane typically has long needle-like crystals; however, if neptunium is present, the needles are shorter. The representative EDS spectra shown in Figure 3.34 and Figure 3.35 indicate that no pure neptunium phase was present. 

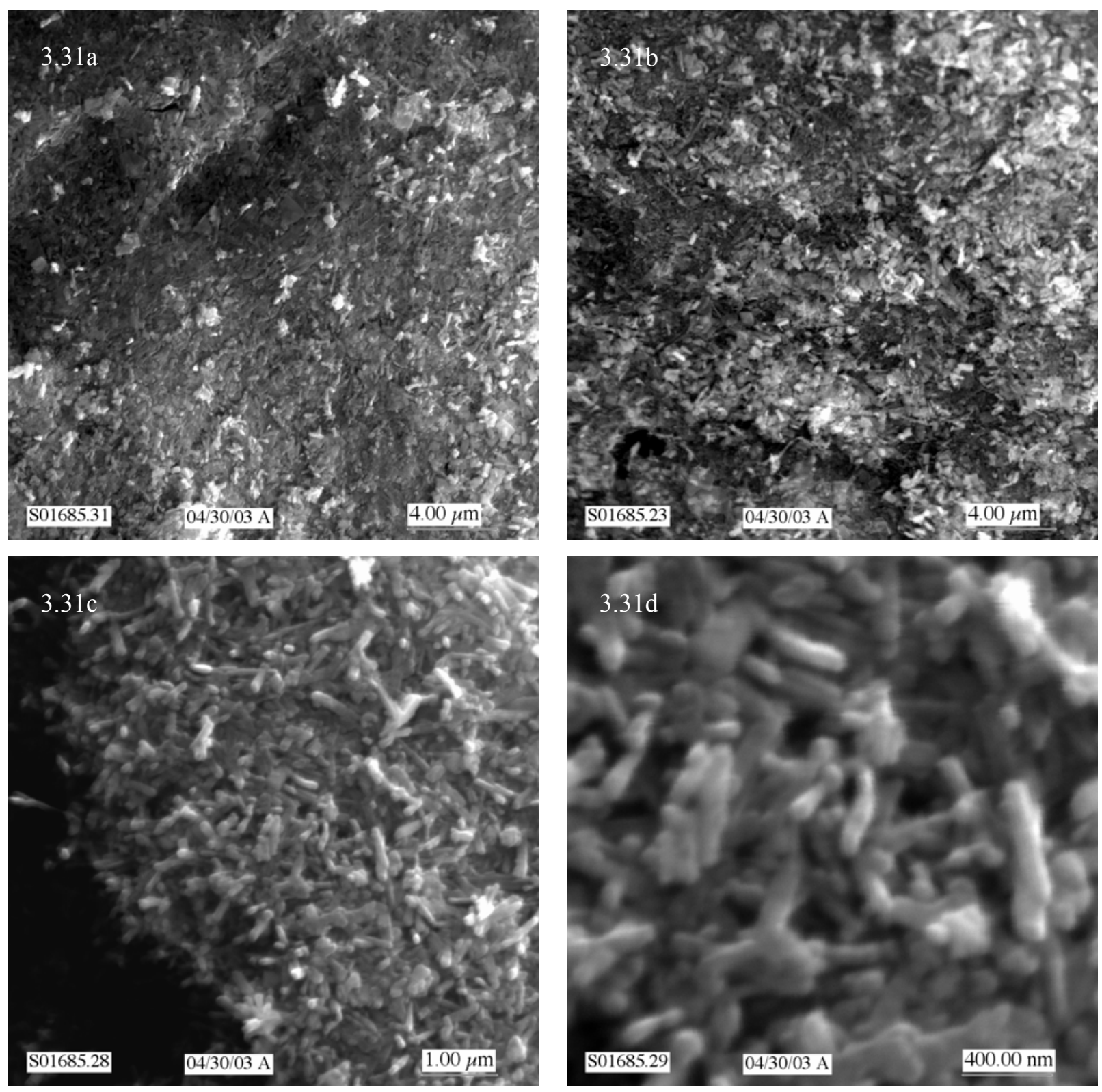

Figure 3.31. SEM Images of Uranophane Sample 4-30-03A (2 mol\% Np) 

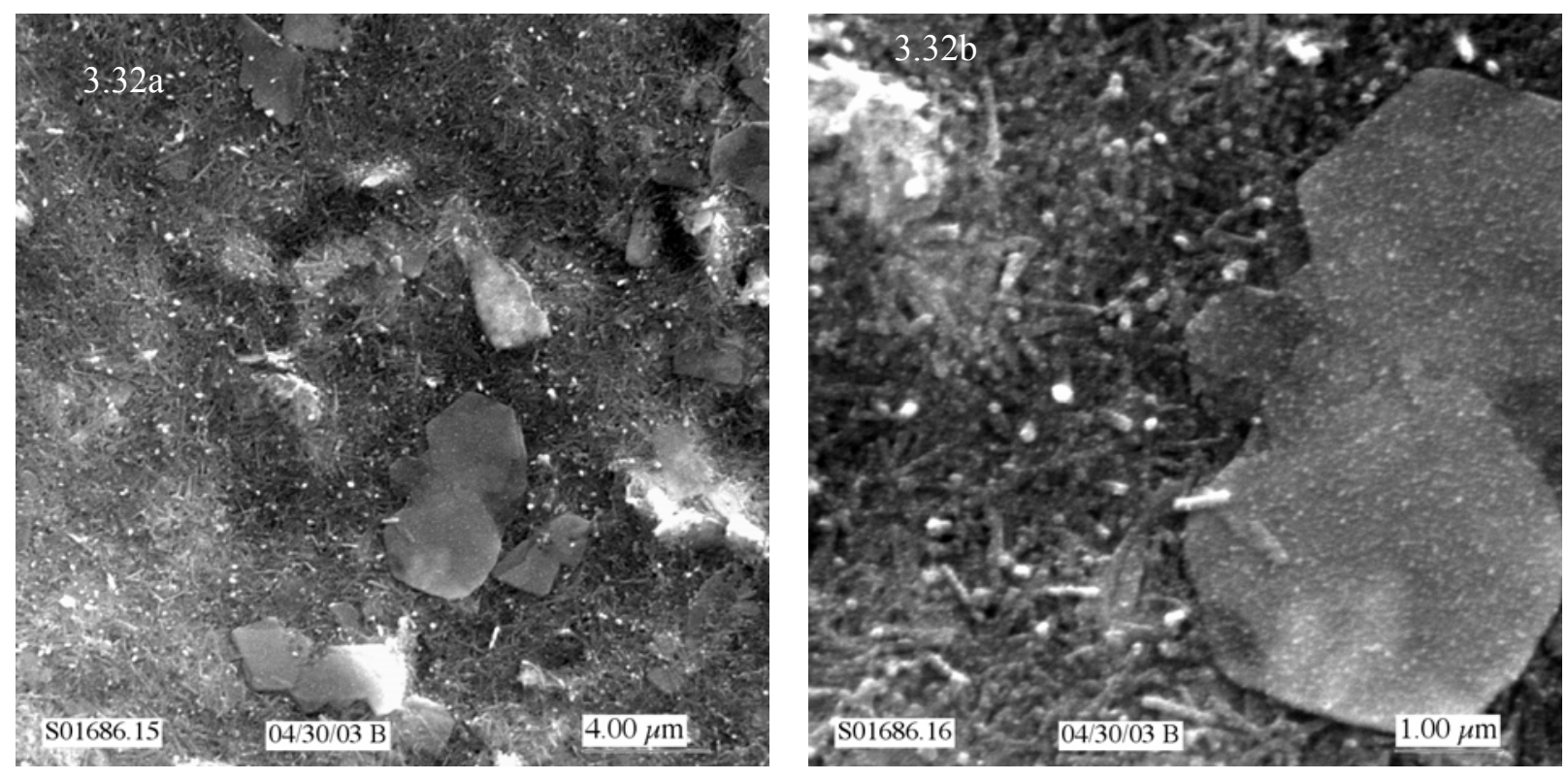

Figure 3.32. SEM Images of Uranophane Sample 4-30-03B (0\% Np) 

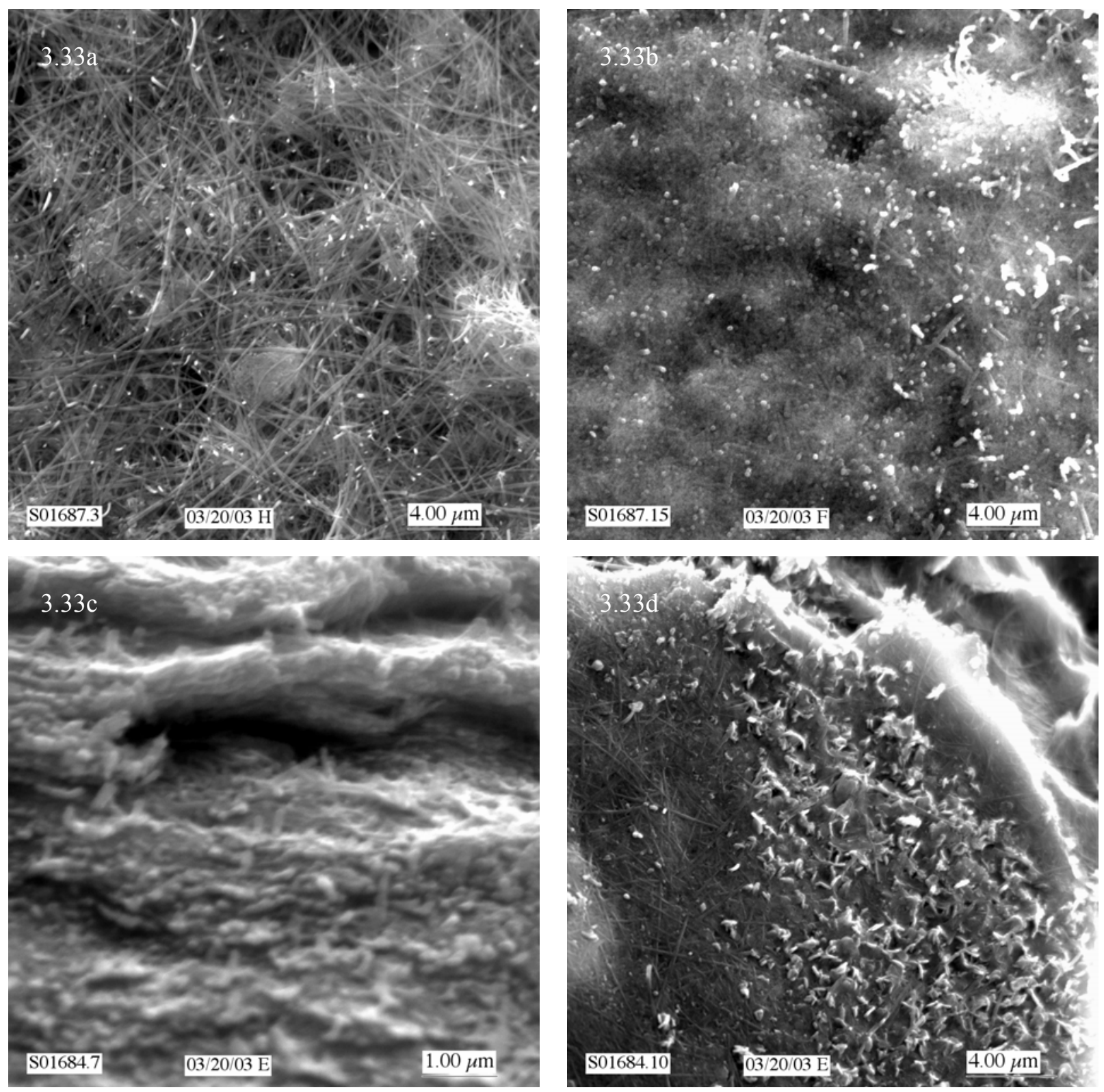

Figure 3.33. SEM Images of Samples 3-20-03E ( 2 mol \% Np, 13c and 13d), 3-20-03F $(1 \mathrm{~mol} \% \mathrm{~Np}, 13 \mathrm{~b}), 3$ and $3-20-03 \mathrm{H}(0 \mathrm{~mol} \% \mathrm{~Np}, 13 \mathrm{a})$ 

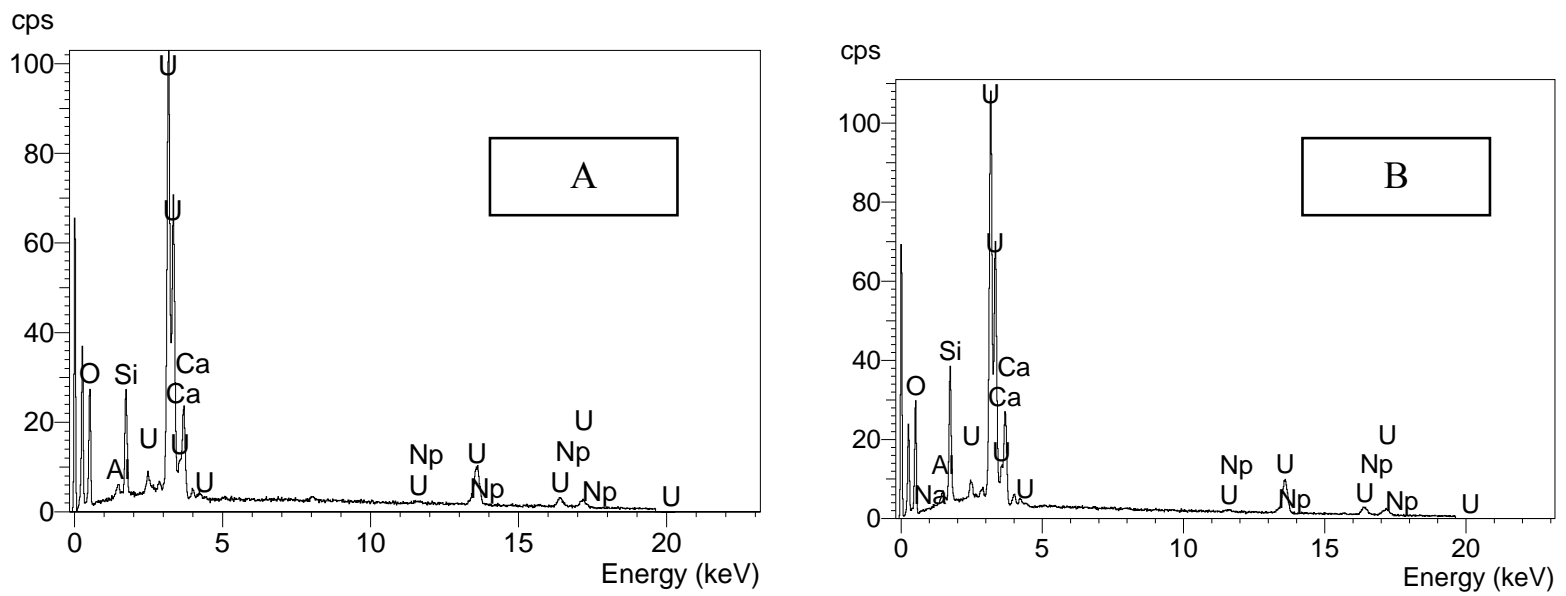

Figure 3.34. EDS Spectra of Samples 4-30-03A and B
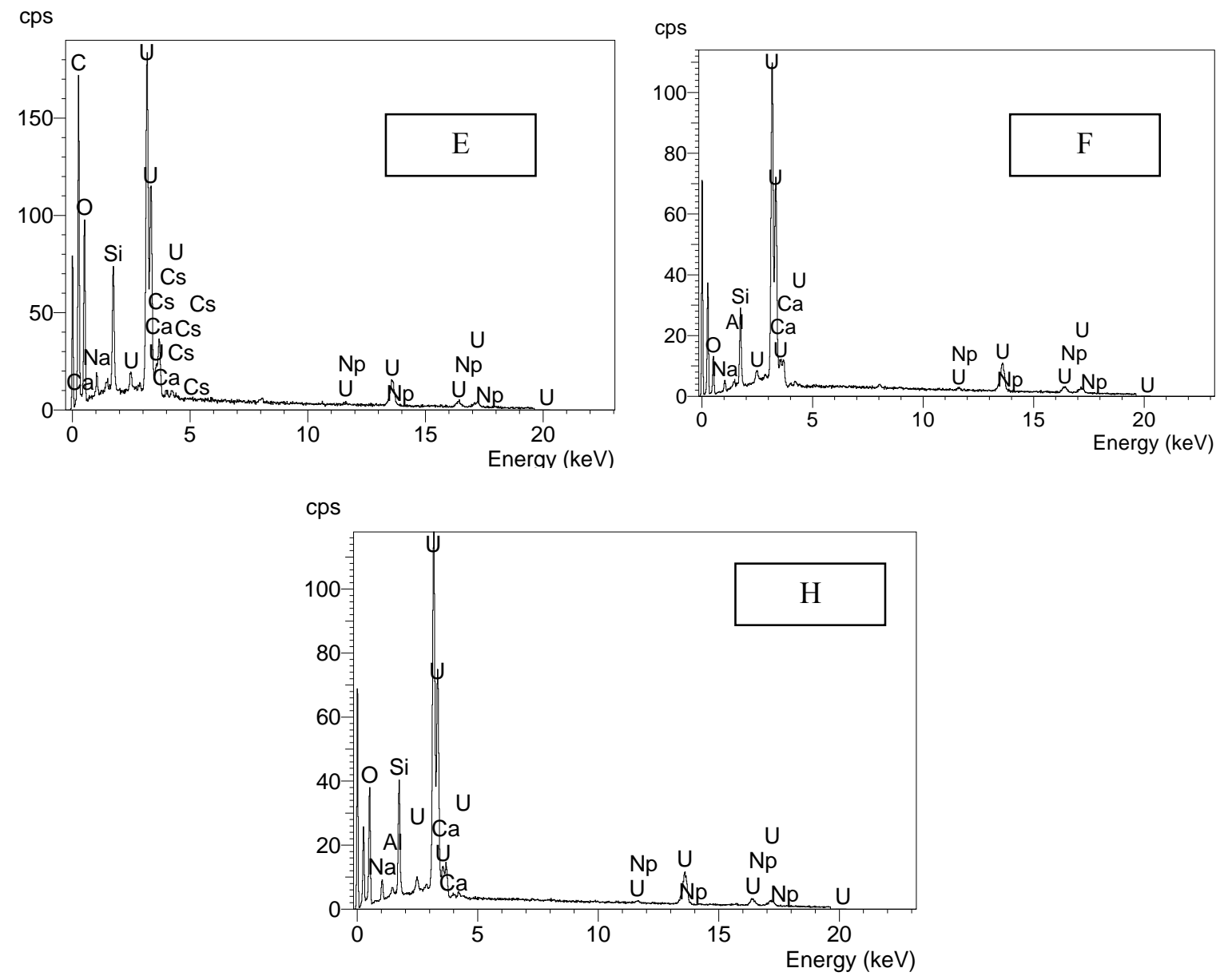

Figure 3.35. EDS Spectra of the 3-20-03 Samples E, F, and H respectively 
Two uranophane samples were analyzed by EELS. Sample 3-20-03E containing $6300 \mathrm{ppm}$ neptunium and sample 3-20-03G containing 1700 ppm neptunium were prepared because of the difference in neptunium content. Analysis of this data as well as a description of how it relates to the repository is described in a recent report by Buck (Buck 2004).

\subsubsection{Characterization of the Second Uranophane Synthesis Set}

The second uranophane synthesis (Table 3.9) was done for two reasons, first, to try to obtain a pure uranophane solid phase, and second, to obtain mass balance in neptunium by measuring all of the solid washes.

Table 3.9. Neptunium Concentrations and Labeling for Second Set

\begin{tabular}{|c|c|c|c|c|}
\hline \hline & U1 & U2 & U3 & U4 \\
\hline Initial mol \% Np & 2 & 1 & 0.5 & 0 \\
\hline $\mathbf{p H}$ & 10 & 10 & 10 & 10 \\
\hline
\end{tabular}

\subsubsection{XRD Data and Lattice Parameters on Samples U1 to U3}

The XRD patterns for the entire uranophane synthesis for the second set indicate that pure uranophane solids were present without detecting any other solid phases (see Figure 3.36 through Figure 3.39). If any other solid phases were present, they are below 5\% of the total bulk sample. There does not appear to be an obvious trend in the lattice parameters with neptunium concentration (Table 3.10). 


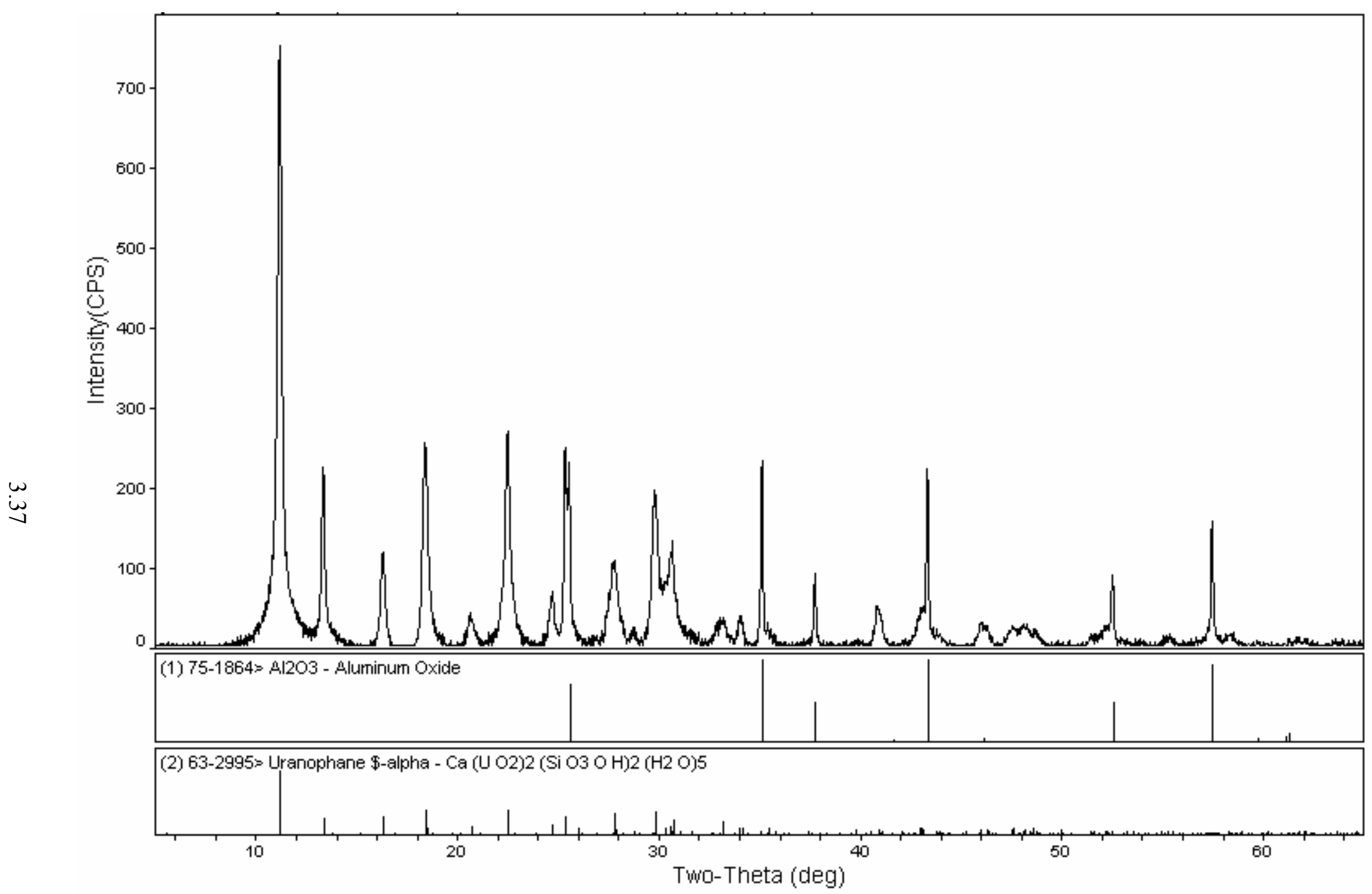

Figure 3.36. XRD Pattern of U1 (uranophane, $2 \mathrm{~mol} \% \mathrm{~Np}$ ) 


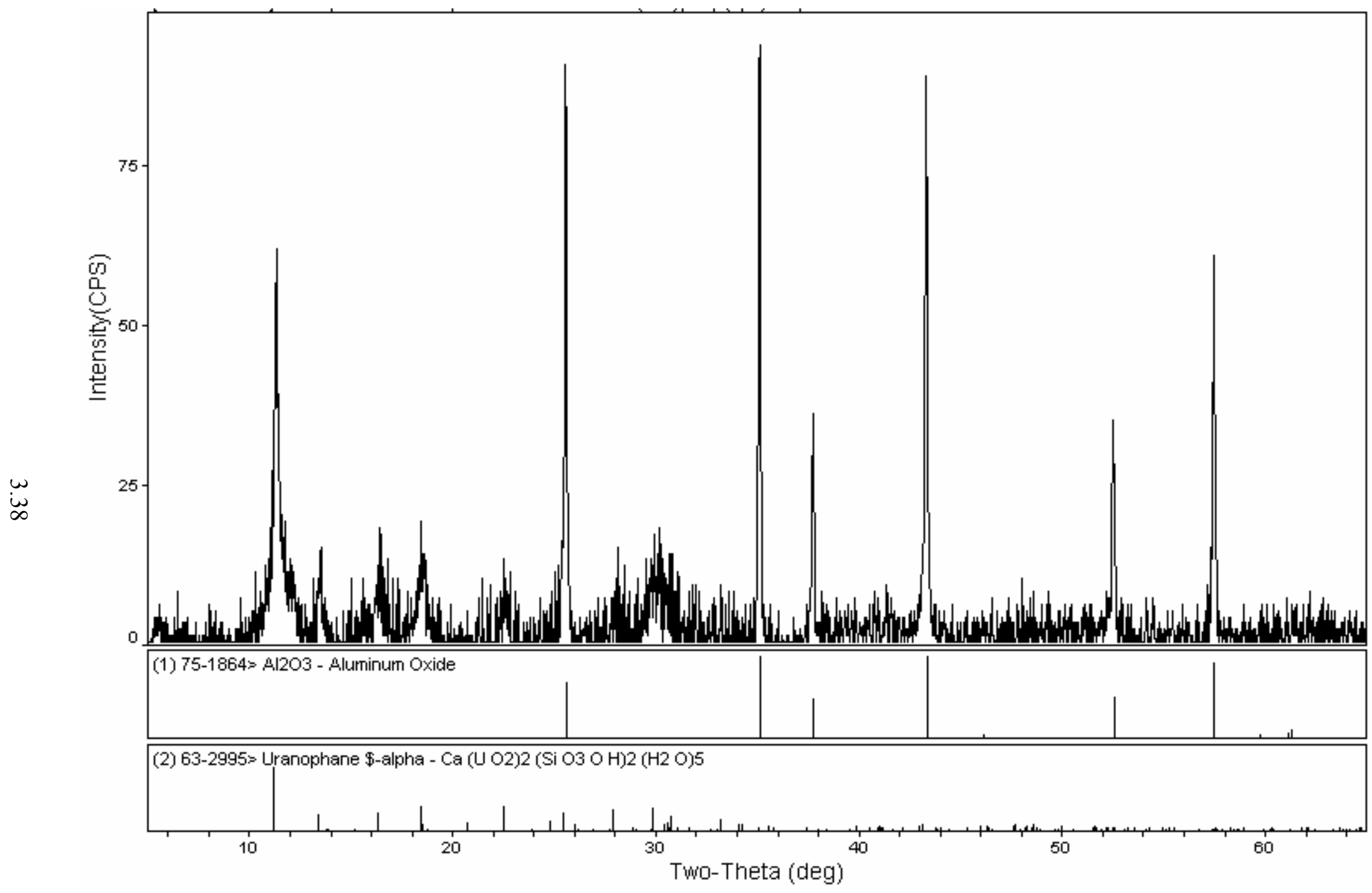

Figure 3.37. XRD Pattern of U2 (uranophane, $1 \mathrm{~mol} \% \mathrm{~Np}$ ) 


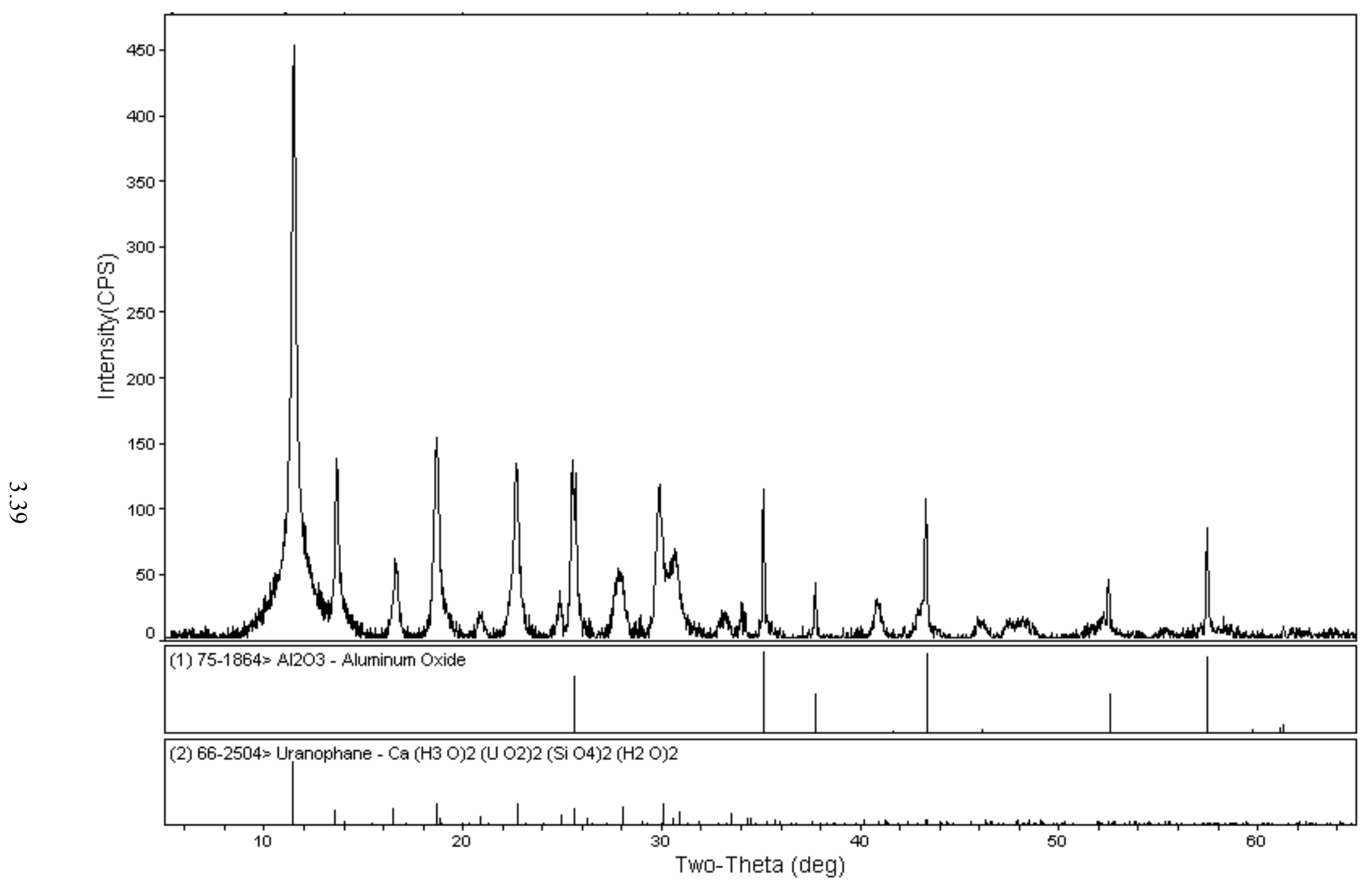

Figure 3.38. XRD Pattern of U3 (uranophane, $0.5 \mathrm{~mol} \% \mathrm{~Np}$ ) 


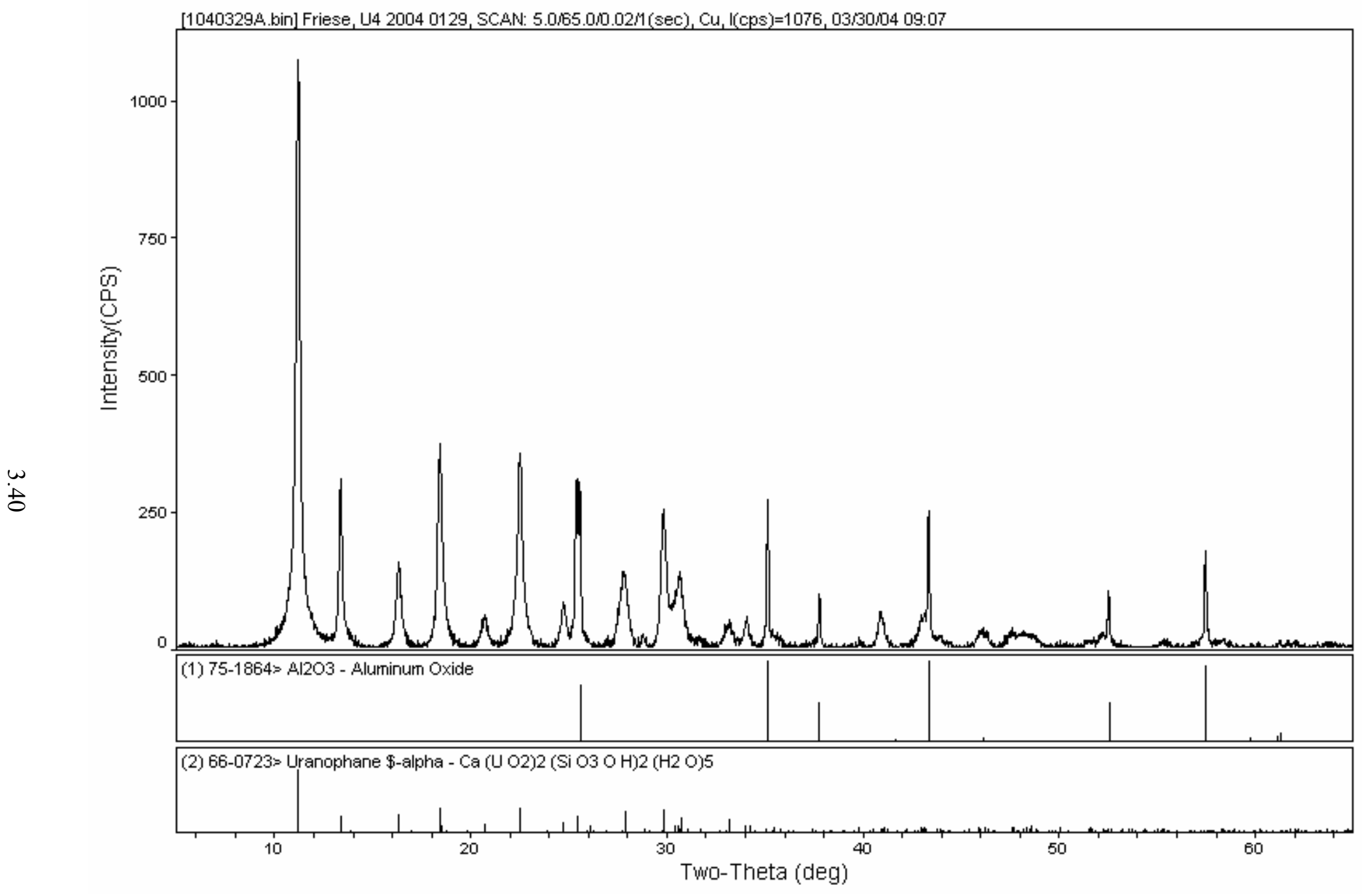

Figure 3.39. XRD Pattern of U4 (uranophane, 0 mol \% Np) 
Table 3.10. Lattice Parameters for Samples U1 Through U4

\begin{tabular}{|c|c|c|c|c|c|}
\hline & mol \% Np & a & b & c & Volume \\
\hline U1 & 2 & $15.92 \pm 0.01$ & $7.00 \pm 0.01$ & $6.67 \pm 0.01$ & 743.57 \\
\hline U2 & 1 & $16.65 \pm 0.01$ & $6.94 \pm 0.01$ & $6.74 \pm 0.01$ & 778.49 \\
\hline U3 & 0.5 & $15.92 \pm 0.01$ & $6.99 \pm 0.01$ & $6.67 \pm 0.01$ & 741.74 \\
\hline U4 & 0 & $15.92 \pm 0.01$ & $7.00 \pm 0.01$ & $6.67 \pm 0.01$ & 743.37 \\
\hline ICDD card 66-2504 & 0 & 15.858 & 6.985 & 6.641 & 735.61 \\
\hline
\end{tabular}

\subsubsection{SEM Micrographs and EDS Spectra for Samples U1 through U4}

The SEM images of the uranophane samples do not show dramatic difference from sample to sample (see Figure 3.40 through Figure 3.43). It is important to notice that the large needle-like crystallites typical of uranophane are not found in the SEM micrographs. This is consistent with previous uranophane samples containing neptunium. Greater crystallinity can form if the samples were allowed to react for longer than one week. Crystal growth in a repository setting will likely be slower and form much more crystalline material over geologic time. The EDS spectra for all samples were identical, without any detection of neptunium (see Figure 3.44).
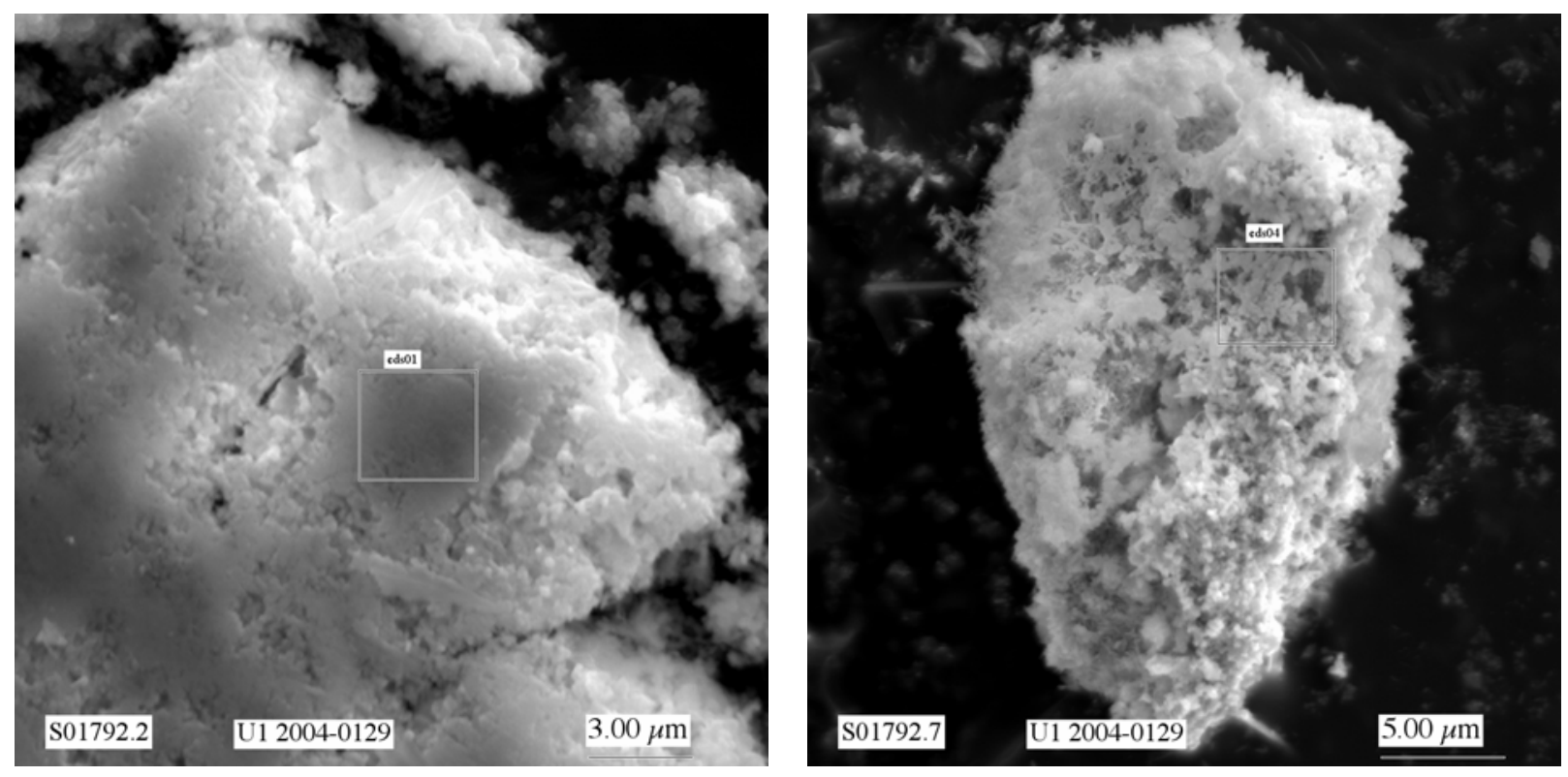

Figure 3.40. SEM Images of Sample U1 (uranophane, 2 mol\% Np) 

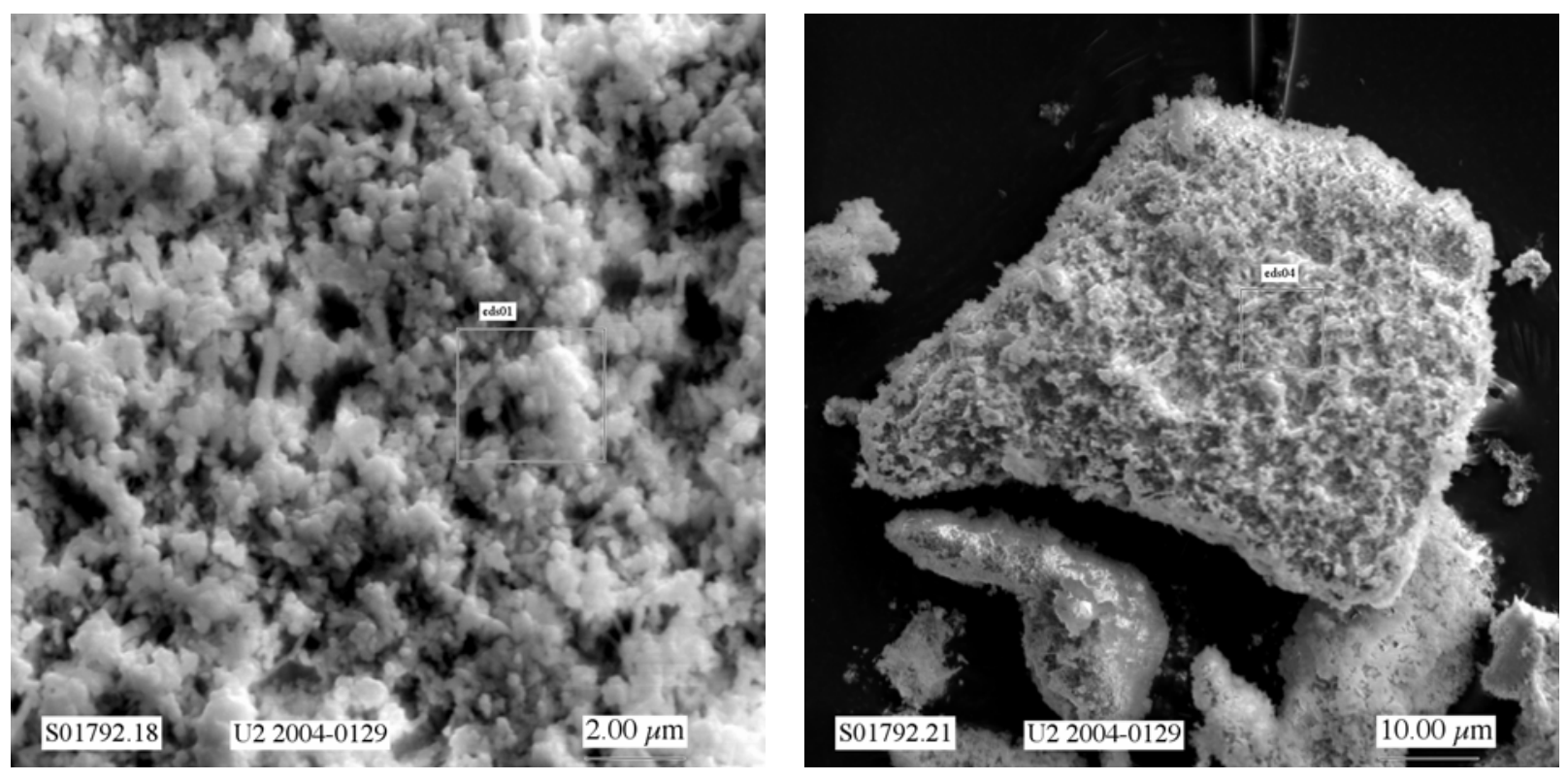

Figure 3.41. SEM Images of Sample U2 (uranophane, $1 \mathrm{~mol} \% \mathrm{~Np}$ )
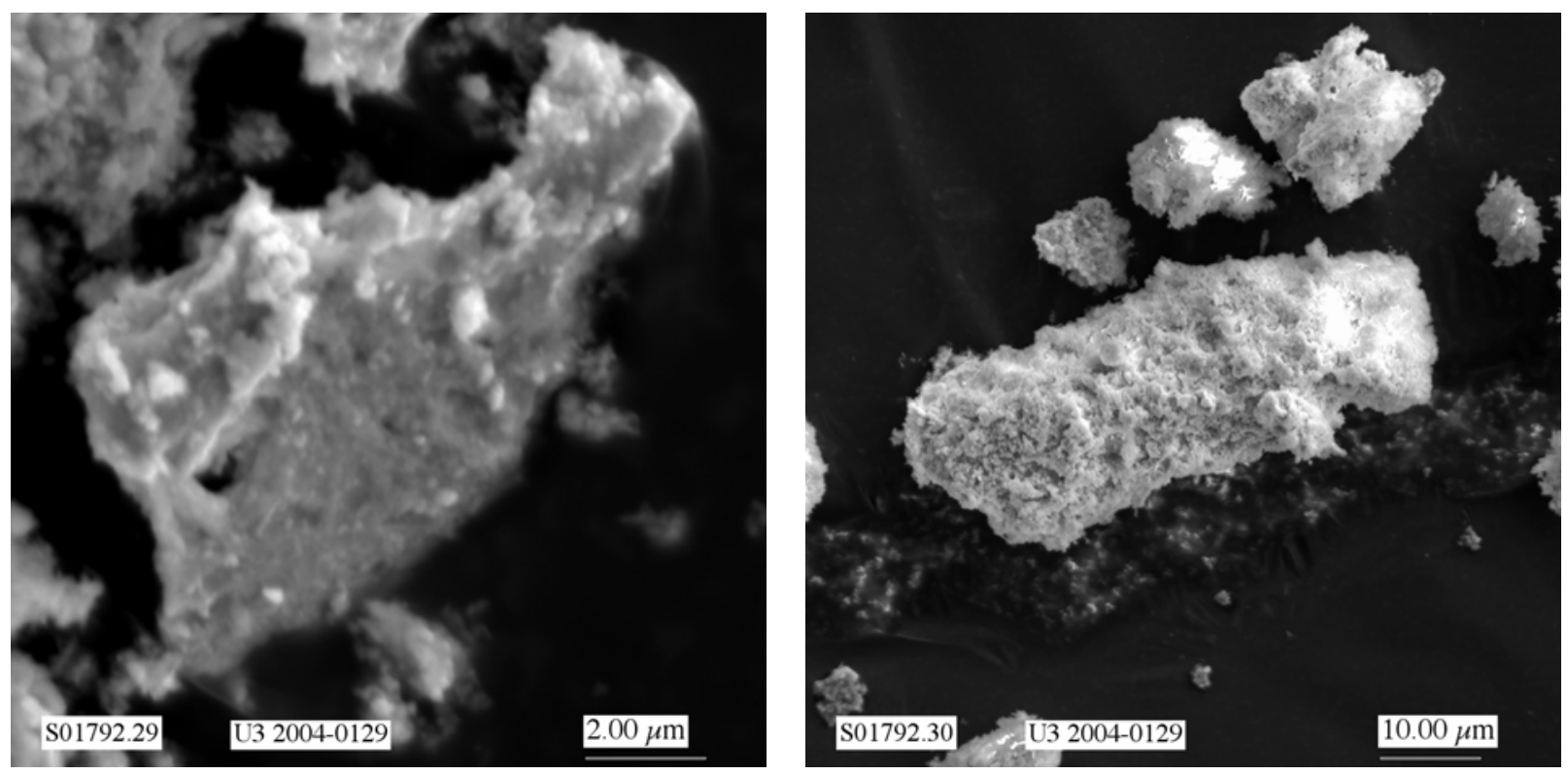

Figure 3.42. SEM Images of Sample U3 (uranophane, $0.5 \mathrm{~mol} \% \mathrm{~Np}$ ) 


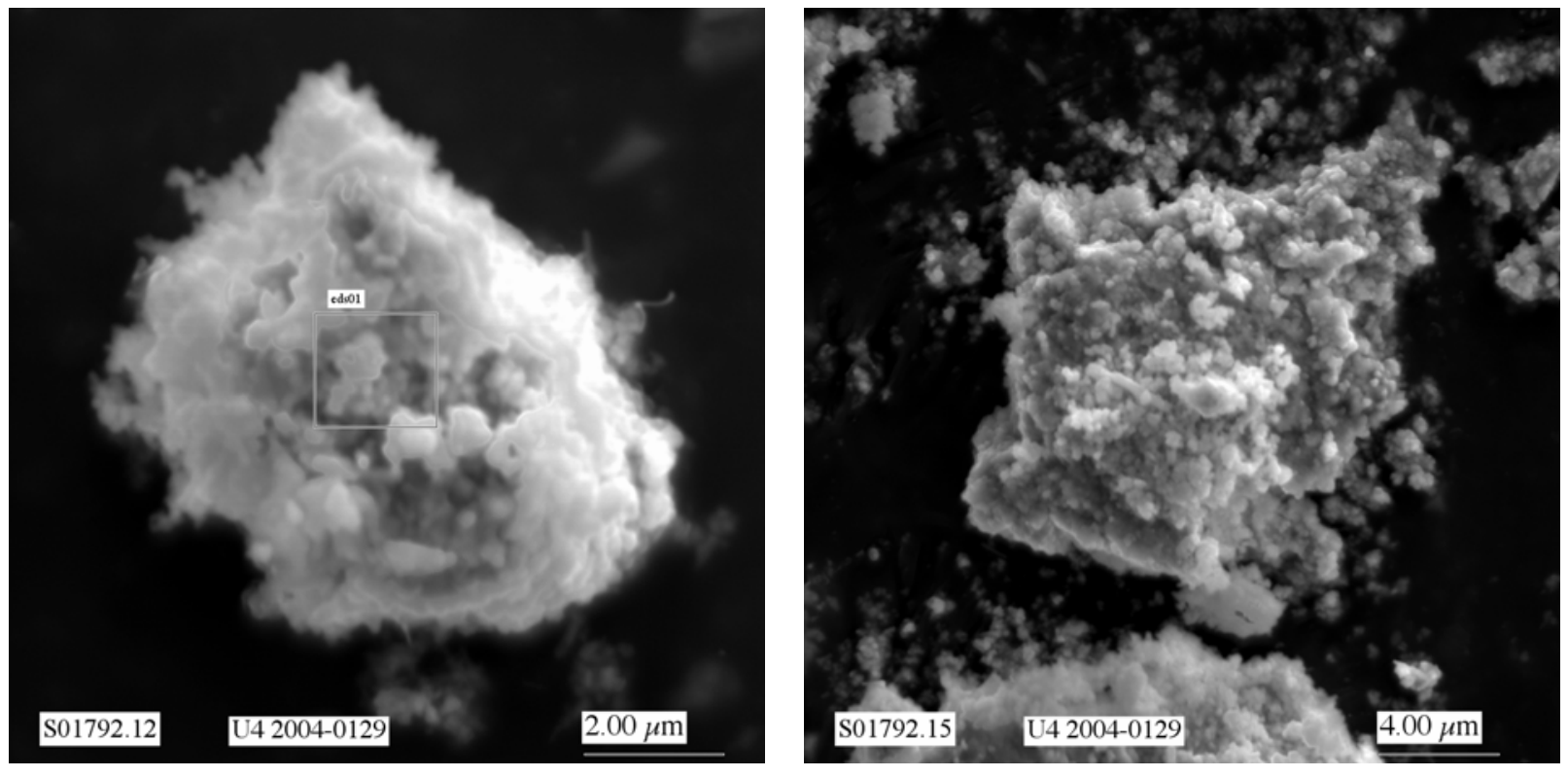

Figure 3.43. SEM Images of Sample U4 (uranophane, 0 mol\% $\mathrm{Np}$ ) 


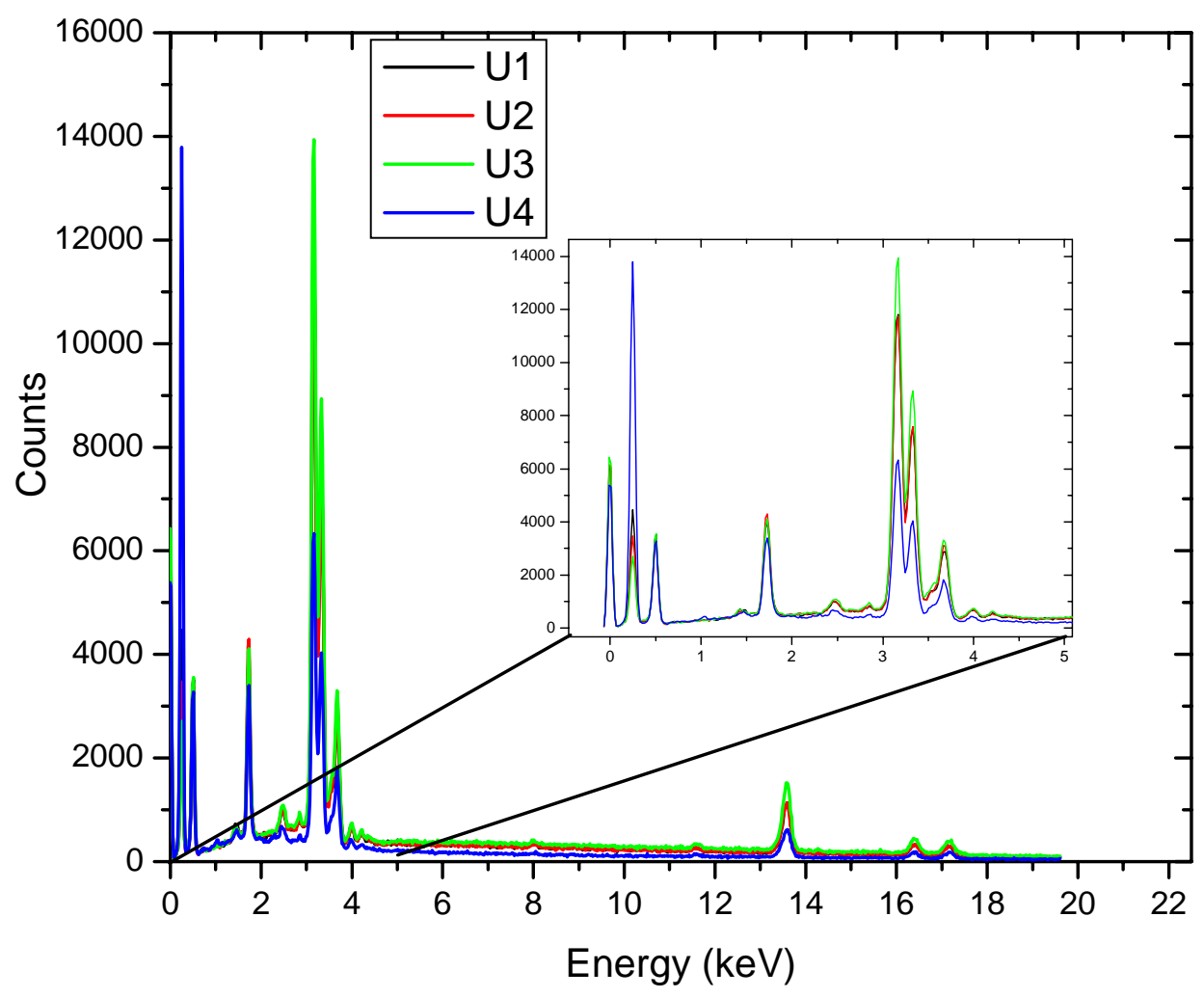

Figure 3.44. EDS Spectra of Samples U1 Through U4 (uranophane)

\subsubsection{Radiochemical Analysis}

The supernatant of each synthesis was sampled. Each solid wash and the uranium minerals were also sampled. Each of these samples was measured by GEA for total ${ }^{237} \mathrm{~Np}$. The analysis of the partitioning of the neptunium between the solutions, rinses, and solids indicate that most of the neptunium was associated with the solid phase. The data indicate that less than $0.3 \%$ of the total neptunium in the system was in solution (see Figure 3.45). Approximately $10 \%$ of the neptunium is removed from the solid when washed with DIW. The total uranium in the washes was not measured. Most of the neptunium was associated with the solid, which is consistent with the first uranophane synthesis set. 


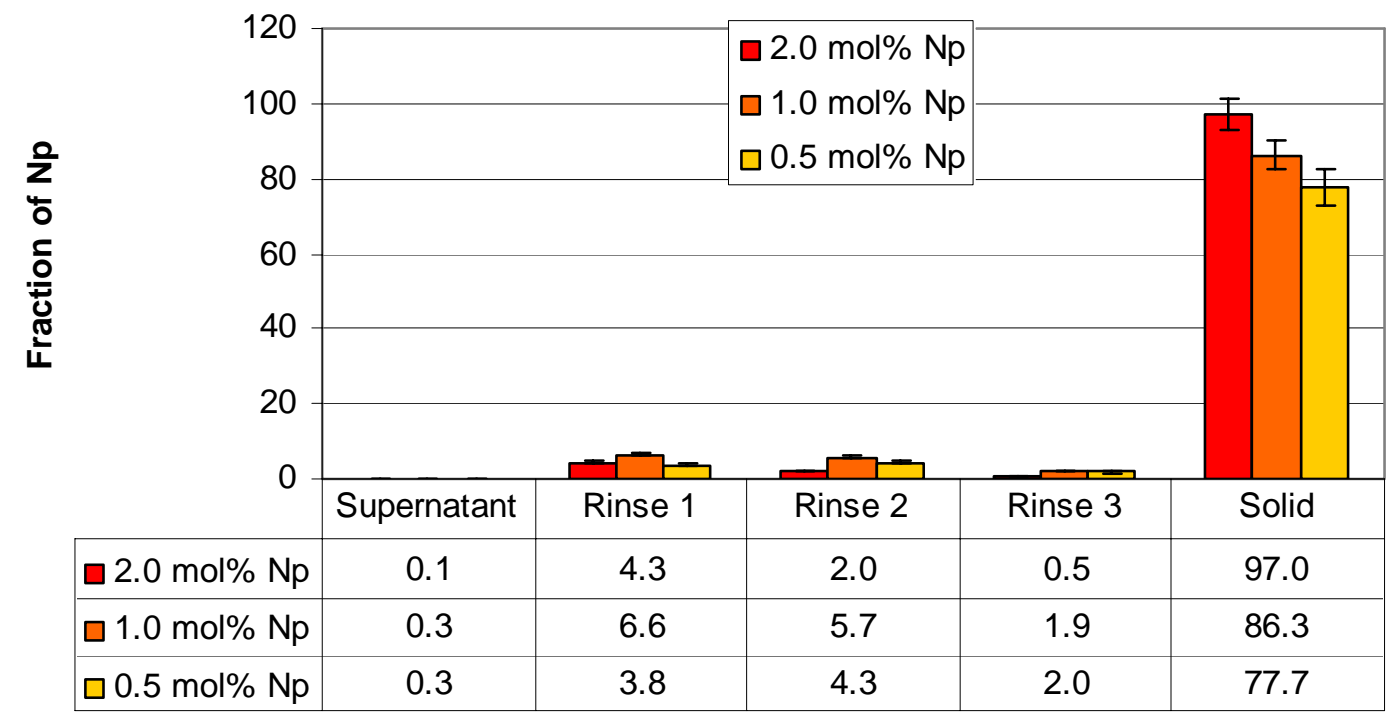

Figure 3.45. Radiochemical Analysis of Second Uranophane Synthesis Set Showing \%Np

\subsection{Sodium Boltwoodite Results}

Four samples of sodium boltwoodite were synthesized. These samples were originally intended to be uranophane samples; however, the XRD patterns indicated sodium boltwoodite rather than uranophane. It is common for sodium boltwoodite to be present with uranophane because of their similar structures. Uranophane and sodium boltwoodite have the same silicate sheet structure and only differ in the inner layer. Boltwoodite has sodium in the inner layer rather than calcium, and the $\mathrm{pH}$ adjustment in the synthesis adds sodium into the system. It is very difficult to obtain a pure solid system. Many repetitions are necessary to get the desired product.

The XRD patterns for these samples (Figure 3.46) indicate that no uranophane was synthesized. The patterns matched sodium boltwoodite. Sodium boltwoodite has the same uranyl-silicate sheet structure as uranophane, but has sodium in the inner layer rather than calcium. Despite the unexpected synthesis, we decided to continue the radiochemical data on theses samples in addition to the other samples.

The radiochemical data (Table 3.11) indicate that neptunium is also associated with this phase. There is still a significant amount of neptunium in solution that is not associated with the solid. The XRD patterns indicate that the sample without neptunium (3-20-03D) is more crystalline than the other samples. This trend appears in all the solids that contain neptunium, regardless of the uranium mineral that is formed. No SEM or EDS data were collected on these samples. 


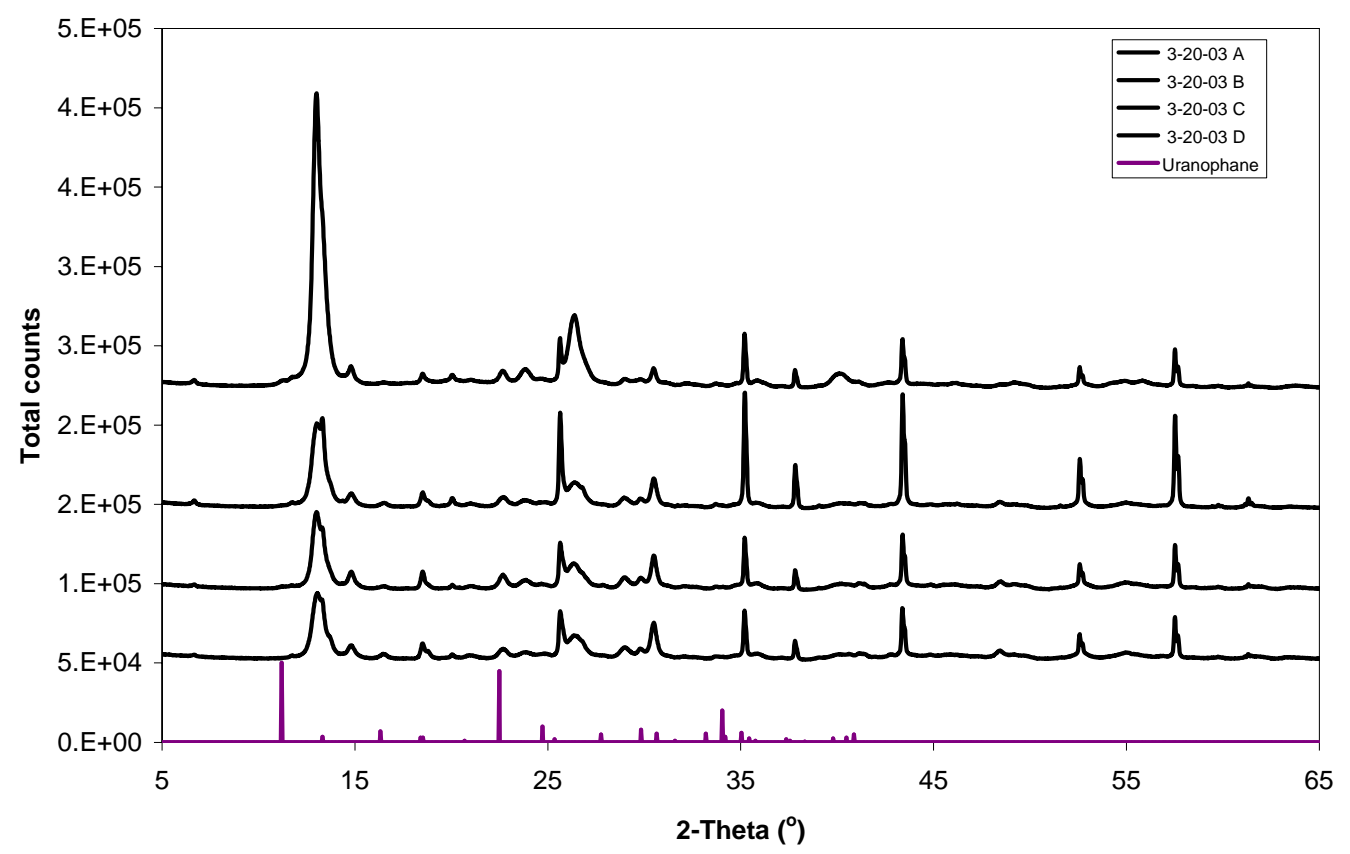

Figure 3.46. XRD Patterns of Sodium Boltwoodite Samples

Table 3.11. Radiochemical Data from Sodium Boltwoodite Tests at Various Neptunium Concentrations

\begin{tabular}{||l|c|c|c|c||}
\hline Sodium Boltwodite & 3-20-03A & 3-20-03B & 3-20-03C & 3-20-03D \\
\hline pH & 5.6 & 5.1 & 5.6 & 5.0 \\
\hline Initial Mol \% Np & 2 & 1 & 0.5 & 0 \\
\hline [U] sol'n & $6.11 \mathrm{E}-6 \mathrm{M}$ & $6.27 \mathrm{E}-5 \mathrm{M}$ & $6.08 \mathrm{E}-6 \mathrm{M}$ & $6.32 \mathrm{E}-5 \mathrm{M}$ \\
\hline [Np] solid & $2700 \mathrm{ppm}$ & $840 \mathrm{ppm}$ & $880 \mathrm{ppm}$ & NA \\
\hline [Np] sol'n & $7.8 \mathrm{E}-5 \mathrm{M}$ & $5.3 \mathrm{E}-5 \mathrm{M}$ & $1.7 \mathrm{E}-5 \mathrm{M}$ & NA \\
\hline \% Np in sol'n & 42 & 55 & 38 & NA \\
\hline
\end{tabular}




\subsection{Overall Trends in Neptunium Association with Uranium Minerals}

There are several trends observed in these scoping tests. It appears that the charge on the sheet structure is important as suggested by others (Burns and Hughes 2003). If the sheet is neutral (as for the schoepite minerals), the inner layer usually only contains water. For neptunium incorporation into the sheet, the inner layer must also incorporate other cations to maintain charge balance unless the neptunium is oxidized to the hexavalent oxidation state. A mineral with a neutral sheet structure is less likely to uptake neptunium $(\mathrm{V})$. This may be overcome by adding other cations in high enough concentrations to force them into the inner layer and replace water as predicted by others (Burns and Hughes 2003; Burns et al. 1996; Burns et al. 1997). Studtite is a unique system due to the oxidizing conditions required to form it and these likely force neptunium to the hexavalent oxidation state.

Minerals that have charged sheets and cations in the inner layer can uptake neptunium to a much greater extent. The charge-balancing mechanism is already in place for these systems, with only the number of inner-layer cations needing to be altered for appropriate charge balance. Uranophane and sodium boltwoodite both had neptunium associated with them to a significant extent. This was also supported by the decrease in crystallinity. The nature of this interaction cannot be unambiguously determined with these data. The neptunium may be incorporated into the solid by replacing the uranium atoms, or it may be sorbed to the surface. From the repository standpoint, the question of incorporation or sorption is unnecessary because they are treated the same in the models. From a scientific standpoint, it is an interesting mechanistic issue.

A second interesting trend is that uranium solids that have neptunium associated with them have a lower crystallinity than pure uranium solids. This is probably because the neptunium interrupts the crystal growth of the minerals. This crystal growth might be due to an interruption by either substituting neptunium for uranium or sorbed neptunium blocking the growth of the crystal structure. The kinetics of this substitution and/or sorbtion is unknown.

Conditions currently modeled in the Yucca Mountain repository include a $\mathrm{pH}$ range from 3 to 12 , ionic strength from $0 \mathrm{M}$ to $8 \mathrm{M}$, and temperatures from $300^{\circ} \mathrm{C}$ at emplacement to $60^{\circ} \mathrm{C}$ at 10,000 years (CRWMS M\&O 2000a). Under these potential conditions, and with the addition of degraded wastepackage material, predicting neptunium behavior is difficult, however, if one chooses likely conditions, one can understand the behavior of various uranium minerals, and in combination with this data, the behavior of neptunium.

Chemistry conditions at short time periods are modeled to be high temperature, high radiation field, and only condensed water once temperatures decrease below the boiling point. Because groundwater constituents (e.g., silicate, calcium) are missing, only two uranium minerals would be expected to form: the uranyl hydroxides (schoepite type minerals) and studtite. For studtite to precipitate, peroxide concentrations must be high $\left(\approx 10^{-5} \mathrm{M}\right)$. Studtite likely will not form in the first 10,000 years because of the high temperatures thermally breaking down peroxide. Schoepite minerals at low $\mathrm{pH}$ will not sorb/incorporate neptunium; however, at neutral to alkaline systems at low ionic strength, neptunium is not in solution and is associated with the uranium minerals. The nature of this association is unknown, 
but indicates that something besides $\mathrm{Np}_{2} \mathrm{O}_{5}$ is controlling the neptunium-solution concentration. Experiments at high ionic strength over a large $\mathrm{pH}$ range are necessary to attempt to understand the mechanism of interaction between neptunium and schoepite-type minerals.

Before the influx of groundwater and the decrease in temperature, the peroxide concentration should be low; however, the environment near the fuel will still be highly oxidizing because of the radiation field. This oxidizing environment will likely drive all the neptunium to the hexavalent oxidation state, which should readily associate to a greater extent with schoepite-type minerals because charge-balancing mechanisms are no longer necessary. Neptunium(VI) should behave similarly in schoepite and studtite, which is known to uptake neptunium over the entire $\mathrm{pH}$ range. This hypothesis has never been formally tested.

SNF fuel tests using drip tests (CRWMS M\&O 2000b) and static water tests (Wilson 1987a; Wilson 1987b; Wilson and Bruton 1989; Wilson 1990) created conditions similar to the expected conditions. The drip tests were at elevated temperatures $\left(90^{\circ} \mathrm{C}\right)$, precluding the buildup of peroxide. Interpretation of the solids analysis is ambiguous because approximately $1 \%$ of the entire fuel matrix reacted over a 10 -year period (CRWMS M\&O 2000c). The static water-bath tests did not do an extensive solids analysis and were conducted at room temperature, which allowed the build up of peroxide. The results from the drip tests and the static water tests are compiled, summarized, and analyzed in a recent report (Friese et al. 2003).

Far field chemistry conditions and in package chemistry will be similar at times beyond the regulatory period when the fuel temperatures are low, uranium and neptunium minerals in contact with ground water and ambient temperatures. At geologic times, the uranyl silicates such as uranophane and sodium boltwoodite are expected to form (Burns and Finch 1999). Initial data on neptunium behavior with these minerals indicate that neptunium(V) (no neptunium(VI) is expected because the oxidizing environment is gone) will associate with these minerals to lower the dissolved concentration of aqueous neptunium. Extreme conditions (high or low $\mathrm{pH}$, temperatures, etc.) are not expected at extended times (100,000 years or greater), thus it is likely that neptunium(V) will be associated with the uranyl minerals unless there are kinetic and/or thermodynamic issues that preclude neptunium(V) interaction with the charged sheet structure minerals. 


\subsection{Conclusions}

The uranium minerals meta-schoepite, studtite, uranophane, and sodium boltwoodite were synthesized in the presences of neptunium(V). One meta-schoepite sample prepared under high $\mathrm{pH}$ conditions had neptunium associated with it at high $\mathrm{pH}$ likely due to hydrolysis; neptunium was found in solution for all meta-schoepite samples prepared under low $\mathrm{pH}$ conditions. The mechanism of this association with $\mathrm{pH}$ is unknown and is the subject of further testing.

Studtite, uranophane, and sodium boltwoodite all had neptunium associated with the solids. Further analysis of the solids indicated that the presence of neptunium may have affected the morphology of the mineral phase. Studtite and uranophane samples lower the solution neptunium concentration by three to four orders of magnitude lower than the current $\mathrm{Np}_{2} \mathrm{O}_{5}$ model. Under all experimental conditions, these minerals all had neptunium associated with them, indicating that if they form under repository conditions, neptunium will likely be associated with the charged sheet uranium mineral phases and potentially with neutral sheet structures under highly oxidizing conditions from a radiation field.

Under a multitude of conditions tested, the neptunium chemistry exists for the potential association with uranium minerals. Further testing is needed to develop a mechanistic understanding of the chemistry. The structural similarity of the uranium(VI), neptunium(V), and neptunium(VI) cations indicate that the two elements should behave chemically similar. The association between uranium minerals and neptunium has been theoretically predicted, and the initial data presented in this report indicate that the predictions are correct. The extent and exact mechanisms are still unclear; however, further work studying this area will lead illuminate certain aspects of actinide chemistry relevant to the repository.

\section{Quality Assurance}

The Pacific Northwest National Laboratory (PNNL) project that performed these studies was required by the U.S. Department of Energy (DOE) Office of Repository Development and Bechtel SAIC Company, LLC (BSC), to develop and implement a Quality Assurance (QA) Program that addressed the requirements of DOE/RW-0333P, Office of Civilian Radioactive Waste Management (OCRWM) Quality Assurance Requirements and Description (QARD), as applicable to the PNNL scope of work. In response to this requirement, the Nuclear Quality Assurance Requirements and Description (NQARD) QA Program was imposed upon the experimental studies described in this document.

The PNNL NQARD QA Program provided an effective management system for conducting and verifying quality-affecting activities in a planned, controlled, and traceable manner. The adequacy, effectiveness, and implementation of the NQARD QA Program have been verified by multiple DOE clients. The NQARD QA Program was audited and approved by the OCRWM Office of Quality Assurance in August 1998 as it related to PNNL work that supports OCRWM's Yucca Mountain Project. The OCRWM Office of Quality Assurance lists PNNL and the NQARD QA Program on their Qualified Supplier 
Listing. As a qualified supplier, OCRWM and BSC attest that the PNNL NQARD QA Program is adequate and is being effectively implemented. The PNNL NQARD QA Program has also been audited by BSC on a triennial basis in 2001 and 2004 to confirm that the PNNL QA Program continue its effective implementation.

Based on the acceptance of the PNNL NQARD QA Program by the OCRWM Office of Quality Assurance in August 1998, and the subsequent evaluations and approval of this QA program by OCRWM and BSC in 2001 and 2004, data obtained following this program are considered qualified and acceptable for use.

The data in this report were generated following the PNNL NQARD QA Program. However, these initial tests were performed to develop and confirm the procedures to be used and guide development of the test plan. Although the results presented in this report were obtained prior to finalization of the test plan, the methods used are identical to those in these subsequent documents.

All QA records generated as a result of implementing the NQARD QA Program for the studies described in this technical report are maintained as permanent records within the PNNL and DOE records management systems. 


\subsection{References}

Abrefah J, SC Marschman, and ED Jenson. 1998. Examination of the Surface Coatings Removed from K-East Basin Fuel Elements. PNNL-11806, Pacific Northwest National Laboratory, Richland, WA.

Allen AO. 1961. The radiation chemistry of water and aqueous solutions. Van Nostrand, Princeton, NJ.

Amme M. 2002. "Contrary effects of the water radiolysis product $\mathrm{H}_{2} \mathrm{O}_{2}$ upon the dissolution of nuclear fuel in natural ground water and deionized water.” Radiochim Acta 90:399-406.

Buck EC, McNamara BK, Douglas M, Hanson BD, 2004 "Possible Incorporation of Neptunium in Uranyl(VI) Alteration Phases" PNNL-14277, Pacific Northwest National Laboratory, Richland, WA

Burns PC, and KC Hughes. 2003. "Studtite, $\left[\left(\mathrm{UO}_{2}\right)\left(\mathrm{O}_{2}\right)\left(\mathrm{H}_{2} \mathrm{O}\right)_{2}\right]\left(\mathrm{H}_{2} \mathrm{O}\right)_{2}$ : The first structure of a peroxide mineral." American Mineralogist 88:1165-1168.

Burns PC, RC Ewing, and ML Miller. 1997. "Incorporation mechanisms of actinide elements into the structures of $\mathrm{U}^{6+}$ phases formed during the oxidation of spent nuclear fuel." Journal of Nuclear Materials 245:1-9.

Burns PC, and RJ Finch. 1999. "Uranium: Mineralogy, Geochemistry and the Environment." Mineralogical Society of America, Reviews in Mineralogy, Vol 38, ISSN 0275-0279.

Burns PC, Deely KM, Skanthakumar S. 2004. "Neptunium incorporation into uranyl compounds that form as alteration products of spent nuclear fuel: Implications for geologic repository performance." Radiochimica Acta 92, 151-159 \)

Chen F, RC Ewing, and SB Clark. 1999. "The Gibbs free energies and enthalpies of formation of U6+ phases: An empirical method of prediction." American Mineralogist 84:650-664.

Christensen H, S Sunder, and DW Shoesmith. 1994. "Oxidation of nuclear fuel $\left(\mathrm{UO}_{2}\right)$ by the products of water radiolysis: development of a kinetic model." Journal of Alloys and Compounds 213:93-99.

CRWMS M\&O. 2000a. In-Package Chemistry Abstraction. ANL-EBS-MD-000037 REV00, Civilian Radioactive Waste Management System Management and Operations, Las Vegas, Nevada.

CRWMS M\&O. 2000b. CSNF Waste Form Degradation: Summary Abstraction. ANL-EBS-MD000015, Civilian Radioactive Waste Management System Management and Operations, Las Vegas, NV.

CRWMS M\&O. 2000c. Commercial Spent Nuclear Fuel Degradation in Unsaturated Drip Tests. WP WP-99432.T., Civilian Radioactive Waste Management System Management and Operations, Las Vegas, NV. 
CRWMS M\&O 2003 Dissolved Concentration Limits of Radionuclide Elementsl. ANL-WIS-MD-000010 REV02, Civilian Radioactive Waste Management System Management and Operations, Las Vegas, NV.

Douglas M, Clark SB, Friese JI, Arey BW, Buck EC, Hanson BD, "Uranium(VI) Solid Phases Formed in the Presence of Neptunium(V)" Environmental Science and Technology (submitted 2004)

Draganic, I., and Draganic, Z. 1971. The radiation chemistry of water. Academic Press, New York/London.

Environmental Management Science Program (EMSP) Interim Report. 2003. Direct Investigations of the immobilization of Radionuclides in the Alteration Phases of Spent Nuclear Fuel, Project Number 73691, Available at: http://emsp.em.doe.gov/

Finch RJ, JA Fortner, EC Buck, and SF Wolf. 2002. "Neptunium incorporation into uranium(VI) compounds formed during aqueous corrosion of neptunium-bearing uranium oxides." Materials Research Society Symposium Proceedings 713:647-654.

Finch RJ. 2002. "Precipitation of crystalline $\mathrm{NpO}_{2}$ during oxidation corrosion of neptunium-bearing uranium oxides.” Materials Research Society Symposium Proceedings 713:639-646.

Finch RJ, Ewing RC. 1992. "The Corrosion of Uraninite Under Oxidizing Conditions.” Journal of Nuclear Materials. 190: 133-156 1992

Friese JI, EC Buck, BK McNamara, BD Hanson, and SC Marschmann. 2003. Existing Evidence for the Fate of Neptunium in the Yucca Mountain Repository. PNNL-14307, Pacific Northwest National Laboratory, Richland, WA.

Gmelin Handbook of Inorganic Chemistry. 1984. Uranium - Supplement Col. D1. Verlag Chemie, Weinheim.

Grambow B, A Loida, P Dressler, H Geckeis, J Gago, I Casas, J De Pablo, J Gimenez, and ME Torrero. 1999. Forschengszentrum Karlsruhe, Technik und Wmwelt, Wissenchaftlich Berichte, FZKA 5702.

Kubatko KH, KB Helean, A Navrotsky, and PC Burns. 2003. "Stability of Peroxide-Containing Uranyl Minerals." Science 302:1191-1193.

Leininger RF, JP Hunt, and DE Koshland. 1985. Chemistry of Uranium. Edited by Joseph J. Katz and Eugene Rabinowitch, Oak Ridge National Laboratory, Oak Ridge, TN.

McNamara, BK, BD Hanson, EC Buck, E Jenson, K Krupka, B Arey, JI Friese 2004 "Corrosion of Commercial Spent Nuclear Fuel 1. Formation of Studtite and Metastudtite" Accepted Radiochemica Acta, 2004

McNamara BK, E Buck, and B Hanson. 2003. "Formation of studtite from corroded spent nuclear fuel." Materials Research Society Symposium Proceedings 757:401. 
McNamara BK, EC Buck, and BD Hanson. 2002. Scientific Basis for Nuclear Waste Management XXVI, Materials Research Society Annual Fall Meeting, December 2-6, 2002, Boston, MA.

Sattonnay G, C Ardois, C Corbel, JF Lucchini, MF Barthe, F Garrido, and D Gosset. 2001. Journal of Nuclear Materials 288:11-19.

Shoesmith DW. 2000. "Fuel corrosion processes under waste disposal conditions." Journal of Nuclear Materials 282:1-31.

Sunder S, and H Christensen. 1993. "Gamma-Radiolysis Of Water Solutions Relevant To The NuclearFuel Waste Management Program” Nuclear Technology 104:403-417.

Sunder S, DW Shoesmith, H Christensen, and HH Miller. 1992. "The Predictions Of Nuclear-Fuel $\left(\mathrm{UO}_{2}\right)$ Dissolution Rates Under Waste-Disposal Conditions" Journal of Nuclear Materials 190:78-86.

Wilson CN. 1987a. Results from NNWSI series 1 Spent Fuel Leach Tests. HEDL-TME-84-30, Westinghouse Hanford Company, Richland, Washington.

Wilson CN. 1987b. Results from Cycles 1 and 2 of NNWSI series 2 Spent Fuel Dissolution Tests. HEDL-TME 85-22, Westinghouse Hanford Company, Richland, Washington.

Wilson CN. 1990. Results from NNWSI Series 3 Spent Fuel Dissolution Tests. PNL-7170, Pacific Northwest Laboratory, Richland, WA.

Wilson CN, and CJ Bruton. 1989. Studies on Spent Fuel Dissolution Behavior Under Yucca Mountain Repository Conditions. PNL-SA-16832, Pacific Northwest National Laboratory, Richland, WA.

Wronkiewicz DJ, JK Bates, TJ Gerding, E Veleckis, and BS Tani. 1992. "Uranium release and secondary phase formation during unsaturated testing of UO2 at $90^{\circ} \mathrm{C}$." Journal of Nuclear Materials 190:107.

Wronkiewicz DJ, JK Bates, SF Wolf, and EC Buck. 1996. "Ten-year results from unsaturated drip tests with $\mathrm{UO}_{2}$ at $90^{\circ} \mathrm{C}$ : Implications for the corrosion of nuclear fuel." Journal of Nuclear Materials 238:78.

Wruck DA, A Brachmann, ER Sylvester, PG Allen, and CEA Palmer. 1999. "Sorption of Np(V) by U(VI) Hydroxide Solids" UCRL-JC-135791, Lawrence Livermore National Laboratory, Livermore, CA . 
PNNL- 14856

\section{Distribution}

No. of

Copies

\section{OFFSITE}

2 Argonne National Laboratory 9700 S. Cass Ave.

Argonne, Illinois 60439

Attn: JC Cunnane

RJ Finch

1 Sandia National Laboratory

1515 Eubank SE

Albuquerque, NM 87123

Attn: PV Brady

10 Bechtel SAIC Company, LLC 1180 Town Center Drive Las Vegas, Nevada 89144

Attn: Howard Adkins Patricia Bernot Yueting Chen (2)

Neil Brown Christine Stockman Terry Steinborn Tom Thornton Dennis Thomas Emma Thomas

4 Washington State University Department of Chemistry Fulmer Hall Pullman, WA 99164

Attn: Sue B. Clark (2) Mathew Douglas (2)
No. of

Copies

\section{OFFSITE}

1 Peter Burns

156 Fitzpatrick Hall

Notre Dame, IN 46556

1 Rod Ewing

Department of Geological Sciences

The University of Michigan

2534 C.C. Little Building

425 E. University Avenue

Ann Arbor, MI 48109-1063

1 Mark Peters

U.S. Department of Energy

OCRWM RW-1

Room 5A-085

1000 Independence Ave SW

Washington, D.C. 20585

1 Margaret Chu

Office of Civilian Radioactive Waste

Management

U.S. Department of Energy

1000 Independence Avenue

Room 5A-085

Washington, D.C. 20585

2 ORD/MTS

U.S. Department of Energy

1551 Hillshire Drive

Las Vegas, NV 89134

Attn: Paige R.Z. Russell

Bob Fish

Distr. 1 
PNNL- 14856

No. of

Copies

\section{ONSITE}

36 Pacific Northwest National Laboratory

J. P. Icenhower

K6-81

B. P. McGrail

K6-81

E. C. Buck

P7-27

B. D. Hanson (20)

P7-27

J. I. Friese (6)

P7-22

B. K. McNamara

P7-25

B. O. Barnes

P8-50

J. Abrefah

P7-27

D. Rai

P7-50

K. Krupka

K6-81

Technical Report Files (2)

Distr. 2 